Prepared in cooperation with the New York City Department of Environmental Protection

Preliminary Analysis of the Hydrologic Effects of Temporary Shutdowns of the Rondout-West Branch Water Tunnel on the Groundwater-Flow System in Wawarsing, New York

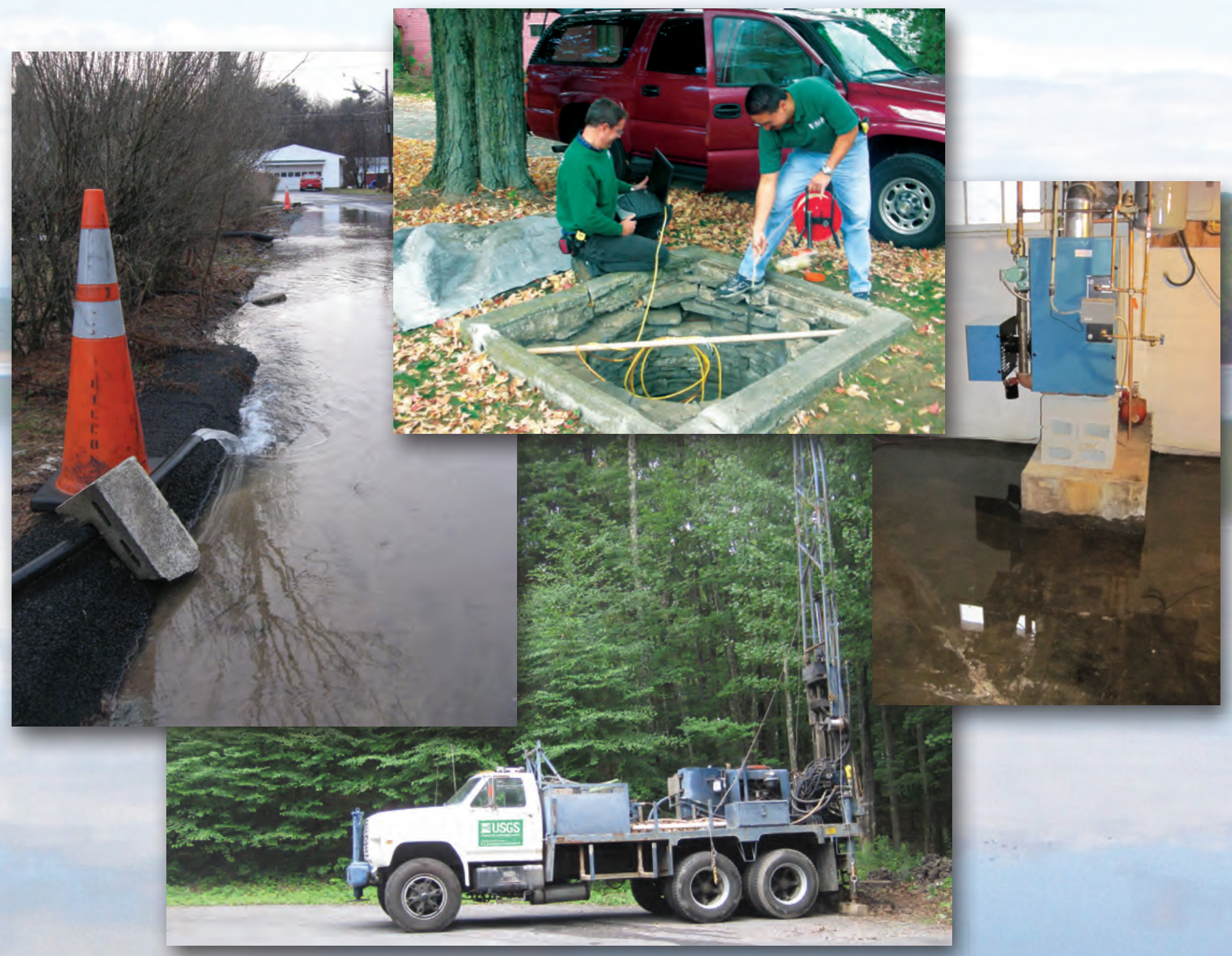

Scientific Investigations Report 2012-5015 


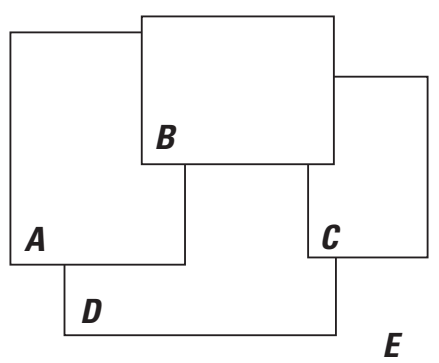

Cover. A, Basement pumpage discharging to a flooded street in Wawarsing, New York; $B$, U.S. Geological Survey scientists measuring groundwater levels in Wawarsing, New York; $C$, Basement flooding in Wawarsing, New York; D, U.S. Geological Survey observation well drilling in Wawarsing, New York; and E, Rondout Reservoir, located in the Towns of Wawarsing and Neversink, New York. (Background photograph of Rondout Reservoir courtesy of New York City Department of Environmental Protection.) 


\section{Preliminary Analysis of the Hydrologic Effects of Temporary Shutdowns of the Rondout-West Branch Water Tunnel on the Groundwater-Flow System in Wawarsing, New York}

By Frederick Stumm, Anthony Chu, Michael D. Como, and Michael L. Noll

Prepared in cooperation with the

New York City Department of Environmental Protection

Scientific Investigations Report 2012-5015 


\section{U.S. Department of the Interior \\ KEN SALAZAR, Secretary \\ U.S. Geological Survey \\ Marcia K. McNutt, Director}

U.S. Geological Survey, Reston, Virginia: 2012

For more information on the USGS - the Federal source for science about the Earth, its natural and living resources, natural hazards, and the environment, visit http://www.usgs.gov or call 1-888-ASK-USGS

For an overview of USGS information products, including maps, imagery, and publications, visit http://www.usgs.gov/pubprod

To order this and other USGS information products, visit http://store.usgs.gov

Any use of trade, product, or firm names is for descriptive purposes only and does not imply endorsement by the U.S. Government.

Although this report is in the public domain, permission must be secured from the individual copyright owners to reproduce any copyrighted materials contained within this report.

Suggested citation:

Stumm, Frederick, Chu, Anthony, Como, M.D., and Noll, M.L., 2012, Preliminary analysis of the hydrologic effects of temporary shutdowns of the Rondout-West Branch Water Tunnel on the groundwater-flow system in Wawarsing, New York: U.S. Geological Survey Scientific Investigations Report 2012-5015, 48 p., at http://pubs.usgs.gov/ sir/2012/5015/. 


\section{Contents}

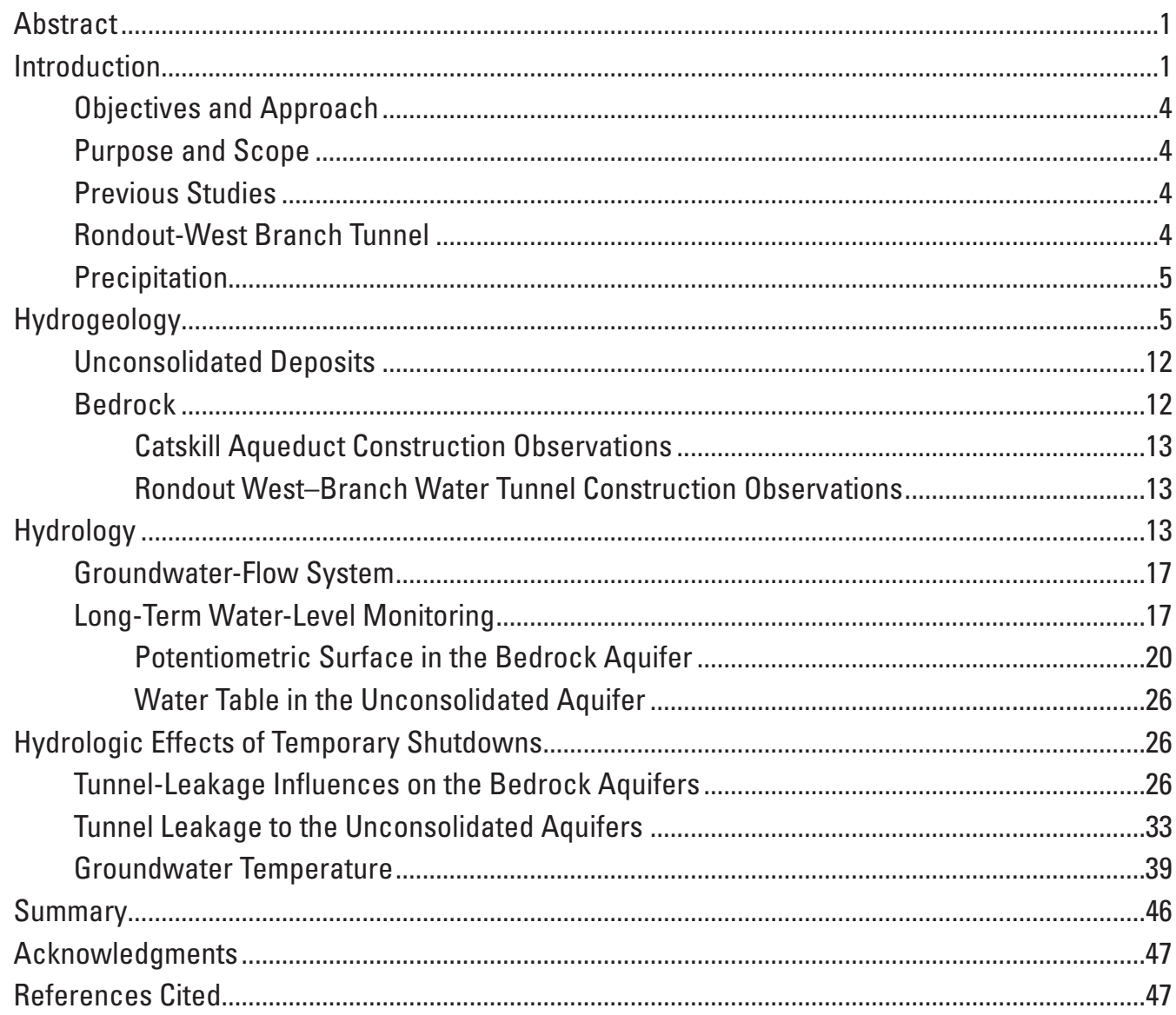

\section{Figures}

1. Map showing location of Wawarsing study area including Summitville, Port Jervis Trough (Kingston to Port Jervis), the four reservoirs (Cannonsville, Pepacton, Neversink, and Rondout), the Delaware Aqueduct, and the Kensico Reservoir in New York

2. Map showing locations of bedrock and unconsolidated-aquifer wells, production wells, and selected surface-water sites within the study area, Town of Wawarsing, Ulster County, New York

3A. Map showing locations of observation wells, production wells, and surfacewater sites; Roundout-West Branch Tunnel geology; and water-inflow rates documented during tunnel construction within the study area, Town of Wawarsing, Ulster County, New York

3B. Cross section of geology observed during New York City Board of Water Supply test borings and Rondout West-Branch Tunnel construction from A to A' within the study area, Town of Wawarsing, Ulster County, New York

4. Graph showing annual precipitation as recorded by the National Weather Service at Central Park, New York County, New York during 1869-2010 
5. Map showing topography and locations of bedrock and unconsolidated aquifer observation wells, production wells, and selected surface-water sites within the study area, Town of Wawarsing, Ulster County, New York

6. Graphs showing water-level and precipitation data for three unconsolidatedaquifer wells, two bedrock wells, and a surface-water site within the study area, Town of Wawarsing, Ulster County, New York: A, Unconsolidated-aquifer well U-1626, October 21, 2008-November 16, 2010; B, bedrock production well U-1629, October 22, 2008-November 16, 2010; C, surface-water site at U.S Geological Survey lake gage 01366807, November 20, 2008-November 16, 2010; D, unconsolidated-aquifer well U-1627, October 21, 2008-December 1, 2010; E, unconsolidated-aquifer well U-1642, September 14, 2008-June 22, 2010; and F, bedrock well U-1628, February 24, 2009-December 1, 2010

7. Hydrogeologic section $B$ to $B^{\prime}$ showing difference in water levels between the unconsolidated and bedrock aquifers, Town of Wawarsing, Ulster County, New York

8. Map showing elevation of the potentiometric surface in the bedrock aquifer within the study area, Town of Wawarsing, Ulster County, New York, March and April 2010

9. Map showing elevation of the potentiometric surface in the bedrock aquifer within the study area, Town of Wawarsing, Ulster County, New York, November 2010

10. Map showing elevation of the water table in the unconsolidated aquifer within the study area, Town of Wawarsing, Ulster County, New York, March and April 2010

11. Map showing elevation of the water table in the unconsolidated aquifer within the study area, Town of Wawarsing, Ulster County, New York, November 2010

12. Graphs showing the potentiometric-surface elevation in bedrock wells, the water level in the Rondout-West Branch Tunnel, and precipitation within the study area, Town of Wawarsing, Ulster County, New York: A, well U-1628, October 25, 2009-February 06, 2010; B, well U-1625, October 25, 2009-February 06, 2010; and C, well U-1653, November 10, 2009-February 06, 2010

13. Map showing maximum water-level response to influence of tunnel leakage on the bedrock aquifer within the study area, Town of Wawarsing, Ulster County, New York, 2009-10

14. Map showing tunnel-leakage influence delay time on water levels in bedrock wells within the study area, Town of Wawarsing, Ulster County, New York, 2009-2010

15. Graphs showing the water-table elevation in unconsolidated aquifer wells, tunnel water level, and precipitation data within the study area, Town of Wawarsing, Ulster County, New York: A, well U-1627, October 25, 2009February 06, 2010; B, well U-1637, January 14, 2010-February 06, 2010; and C, well U-1641, October 25, 2009-February 06, 2010

16. Map showing maximum water-level response to influence of tunnel leakage on the unconsolidated aquifer within the study area, Town of Wawarsing, Ulster County, New York

17. Map showing tunnel-leakage influence delay time on water levels in unconsolidated-aquifer wells and surface-water sites within the study area, Town of Wawarsing, Ulster County, New York, 2009-10

18. Map showing groundwater temperature in bedrock wells within the study area, Town of Wawarsing, Ulster County, New York, August 2010 


\section{Tables}

1. Site information for groundwater wells and selected surface-water sites within the study area, Town of Wawarsing, Ulster County, New York

\section{Conversion Factors, Datum, and Abbreviations}

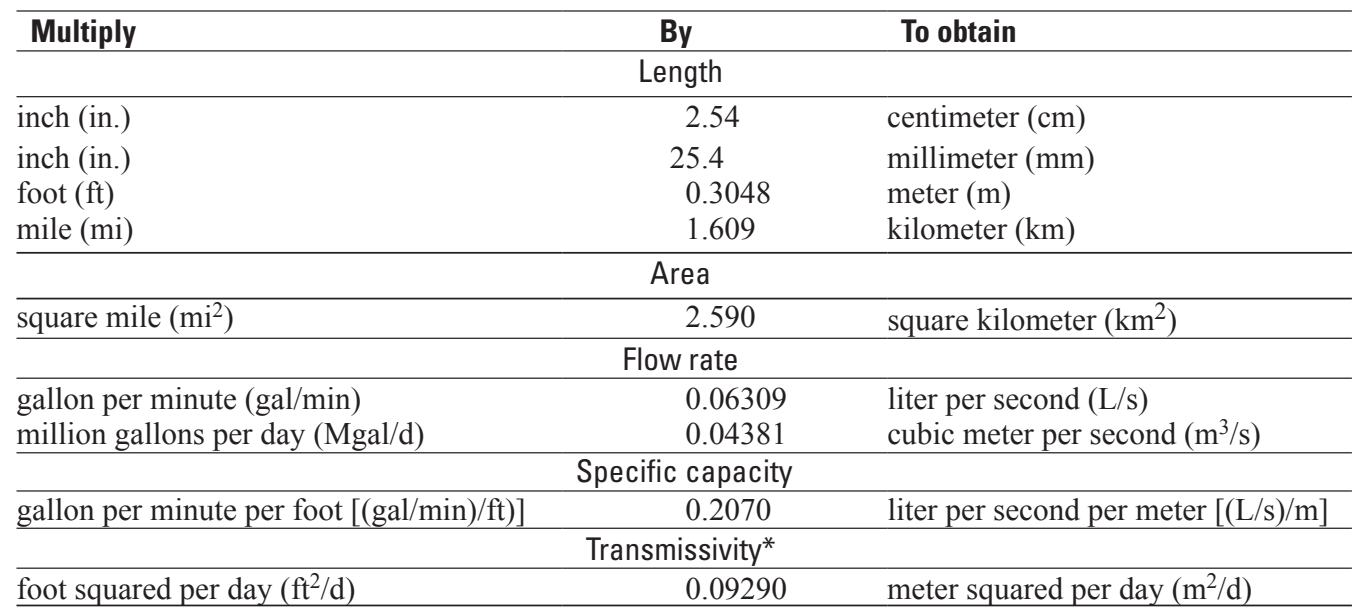

Temperature in degrees Celsius $\left({ }^{\circ} \mathrm{C}\right)$ may be converted to degrees Fahrenheit $\left({ }^{\circ} \mathrm{F}\right)$ as follows:

$$
{ }^{\circ} \mathrm{F}=\left(1.8 \times{ }^{\circ} \mathrm{C}\right)+32
$$

Temperature in degrees Fahrenheit $\left({ }^{\circ} \mathrm{F}\right)$ may be converted to degrees Celsius $\left({ }^{\circ} \mathrm{C}\right)$ as follows:

$$
{ }^{\circ} \mathrm{C}=\left({ }^{\circ} \mathrm{F}-32\right) / 1.8
$$

Vertical coordinate information is referenced to the North American Vertical Datum of 1988 (NAVD 88).

Horizontal coordinate information is referenced to the North American Datum of 1983 (NAD 83) except in figure 5, where it is referenced to the North American Datum of 1927 (NAD 27).

Elevation, as used in this report, refers to distance above the vertical datum.

*Transmissivity: The standard unit for transmissivity is cubic foot per day per square foot times foot of aquifer thickness $\left[\left(\mathrm{ft}^{3} / \mathrm{d}\right) / \mathrm{ft}^{2}\right] \mathrm{ft}$. In this report, the mathematically reduced form, foot squared per day $\left(\mathrm{ft}^{2} / \mathrm{d}\right)$, is used for convenience. 


\section{List of Acronyms and Abbreviations}

$\begin{array}{ll}\text { BLS } & \text { below land surface } \\ \text { E. coli } & \text { Escherichia coli } \\ \text { GPS } & \text { Global Positioning System } \\ \text { NOAA } & \text { National Oceanic and Atmospheric Administration } \\ \text { NWS } & \text { National Weather Service } \\ \text { NYCBWS } & \text { New York City Board of Water Supply } \\ \text { NYCDEP } & \text { New York City Department of Environmental Protection } \\ \text { NYSDEC } & \text { New York State Department of Environmental Conservation } \\ \text { RWB } & \text { Rondout-West Branch } \\ \text { USGS } & \text { U.S. Geological Survey }\end{array}$




\title{
Preliminary Analysis of the Hydrologic Effects of Temporary Shutdowns of the Rondout-West Branch Water Tunnel on the Groundwater-Flow System in Wawarsing, New York
}

\author{
By Frederick Stumm, Anthony Chu, Michael D. Como, and Michael L. Noll
}

\section{Abstract}

Flooding of streets and residential basements, and bacterial contamination of private-supply wells with Escherichia coli (E. coli) are recurring problems in the Rondout Valley near the Town of Wawarsing, Ulster County, New York. Leakage from the Rondout-West Branch (RWB) Water Tunnel and above-normal precipitation have been suspected of causing elevated groundwater levels and basement flooding. The hydrology of a 12 -square-mile study area within the Town of Wawarsing was studied during 2008-10. A network of 41 wells (23 unconsolidatedaquifer and 18 bedrock wells) and 2 surface-water sites was used to monitor the hydrologic effects of four RWB Water Tunnel shutdowns. The study area is underlain by a sequence of northeast-trending sedimentary rocks that include limestone, shale, and sandstone. The bedrock contains dissolution features, fractures, and faults. Inflows that ranged from less than 1 to more than 9,000 gallons per minute from the fractured bedrock were documented during construction of the 13.5-foot-diameter RWB Water Tunnel through the sedimentary-rock sequence 710 feet ( $\mathrm{ft}$ ) beneath the studyarea valley. Glacial sediments infill the valley above the bedrock sequence and consist of clay, silt, sand, and gravel. The groundwater-flow system in the valley consists of both fractured-rock and unconsolidated aquifers. Water levels in both the bedrock and unconsolidated aquifers respond to variations in seasonal precipitation. During the past 9 years (2002-10), annual precipitation at Central Park, N.Y., has exceeded the 141-year mean.

Potentiometric-surface maps indicate that groundwater in the bedrock flows from the surrounding hills on the east and west sides of the valley toward the center of the valley, and ultimately toward the northeast. On average, water levels in the bedrock aquifer had seasonal differences of $5.3 \mathrm{ft}$. Analysis of hydrographs of bedrock wells indicates that many of these wells are affected by the RWB Tunnel leakage. Tunnelleakage influences (water-level and temperature changes) in the bedrock aquifer were measured at distances up to 7,000 ft from the RWB Tunnel. Water levels in the bedrock changed as much as $12 \mathrm{ft}$ within 0.5 hour during tunnel shutdowns. Nine of the 10 wells that responded to the shutdowns showed a water-level response of $5 \mathrm{ft}$ or greater. Changes in water levels ranged from 1.5 to $12 \mathrm{ft}$, with tunnel-leakage influence delay times ranging from 0.5 to 60 hours. Many of the longest tunnel-influence delay times and smallest water-level changes were in wells located closest to the tunnel in shale. Tunnelinfluence response of the bedrock aquifer is consistent with its preliminary characterization as an anisotropic aquifer with greater transmissivity along bedding strike than across bedding strike. This tunnel-influence response is also consistent with the likely presence of discrete high-transmissivity networks along fractured limestone beds that have undergone dissolution. A lack of bedrock observation wells in half of the study area hampered a more thorough analysis of the extent of leakage from the RWB Tunnel in the study area.

On average, water levels in the unconsolidated aquifer had a seasonal difference of $5 \mathrm{ft}$. Some unconsolidated-aquifer wells indicated water-level changes due to tunnel leakage. The locations of unconsolidated-aquifer wells with measurable water-level changes due to tunnel leakage correlated with those in the bedrock. Water levels in the unconsolidated aquifer changed as much as $2.5 \mathrm{ft}$ within 18 hours of tunnel shutdowns, but water-level changes in some unconsolidatedaquifer wells were smaller or nonexistent.

\section{Introduction}

Seasonal flooding of streets and residential basements and bacterial contamination of private-supply wells with Escherichia coli (E. coli) are recurring problems in the Rondout Valley near the Town of Wawarsing, Ulster County, New York (fig. 1). Street flooding may be related to the low infiltration rates of local soils and ineffective stormwaterdrainage networks. The E. coli contamination of shallow 


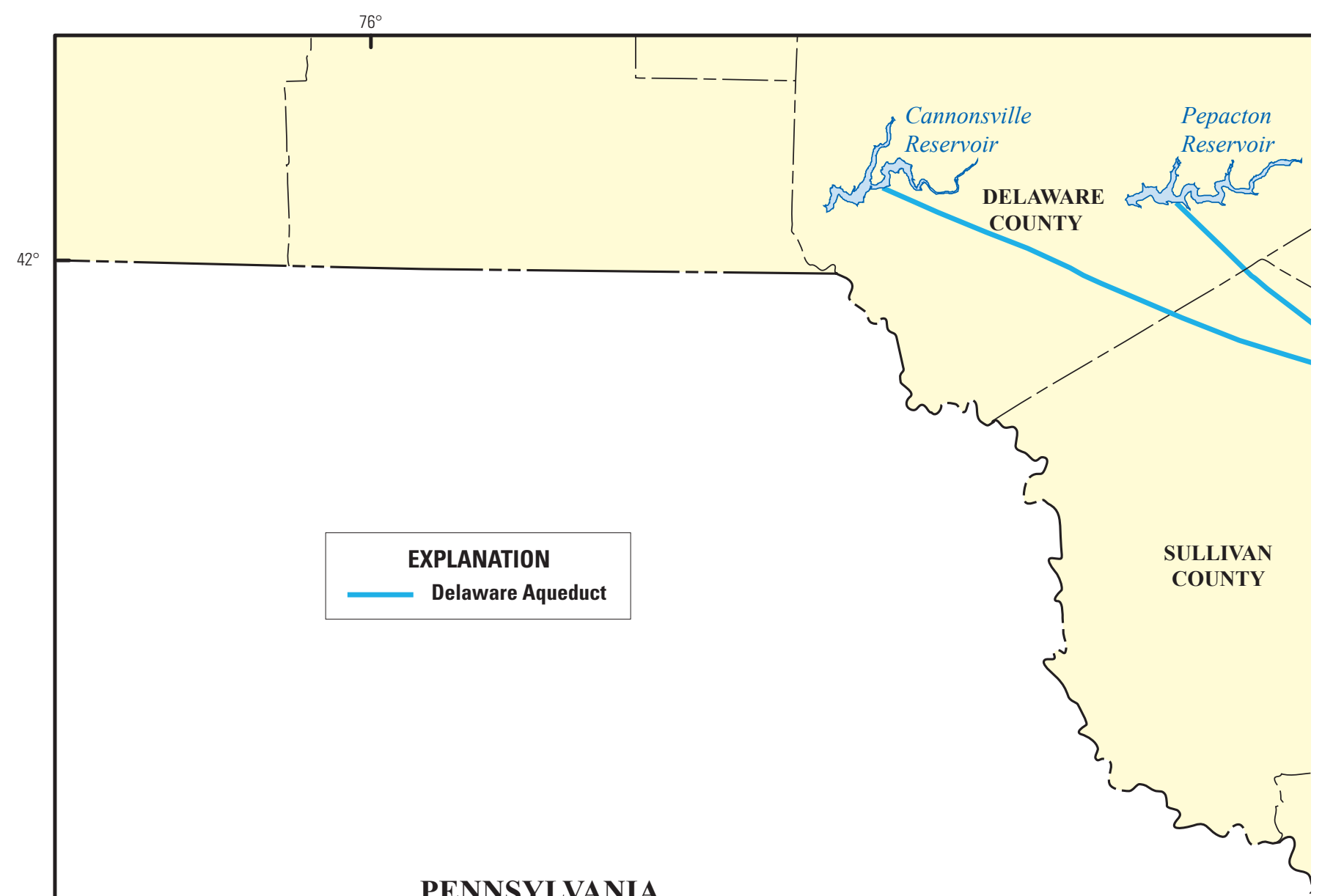

\section{PENNSYLVANIA}

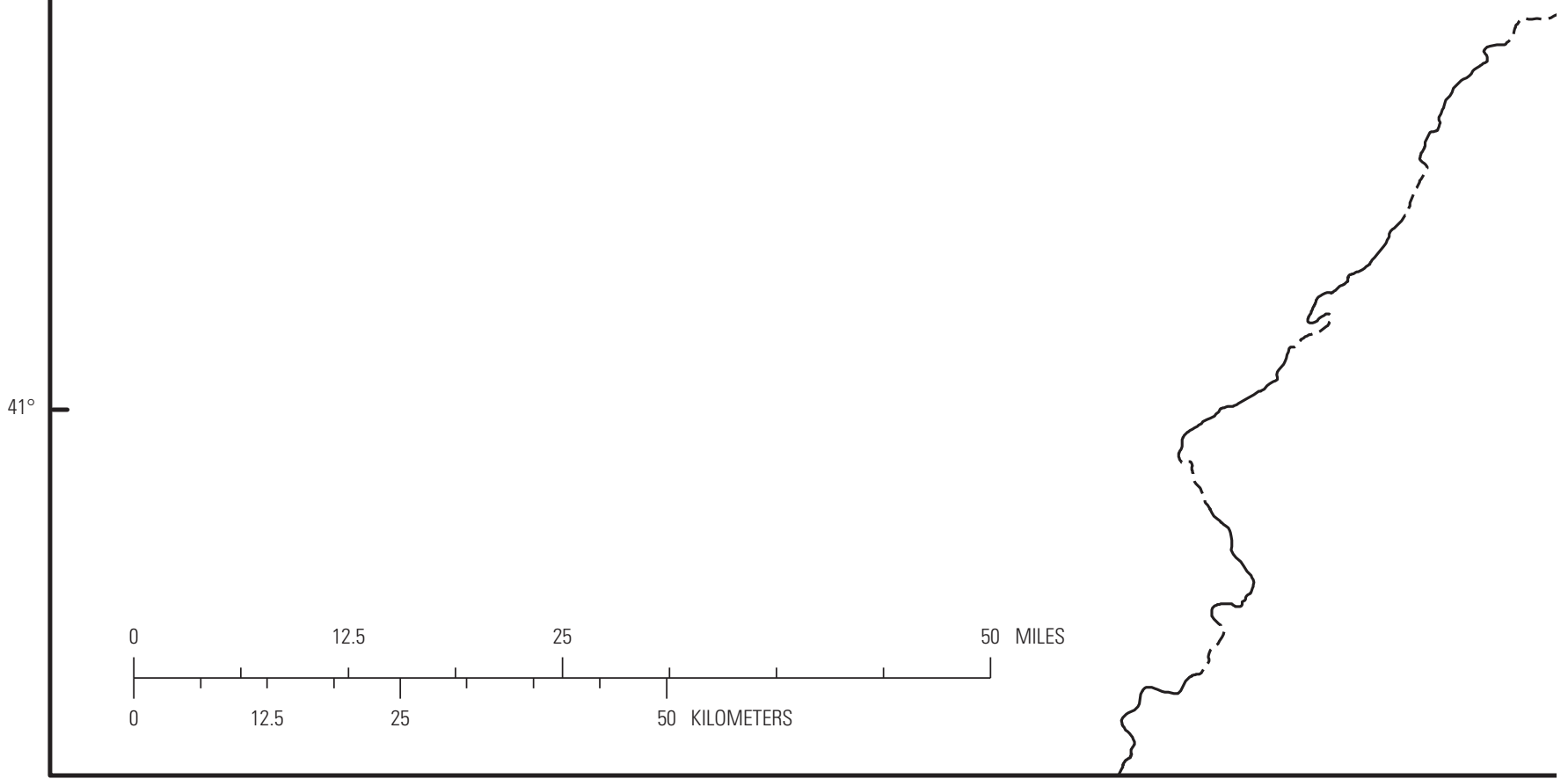

Base from U.S. Geological Survey Digital Data 1:100,000 series Lambert Conformal Conic Projection

North American Datum of 1983

Figure 1. Location of Wawarsing study area including Summitville, Port Jervis Trough (Kingston to Port Jervis), the four reservoirs (Cannonsville, Pepacton, Neversink, and Rondout), the Delaware Aqueduct, and the Kensico Reservoir in New York. 


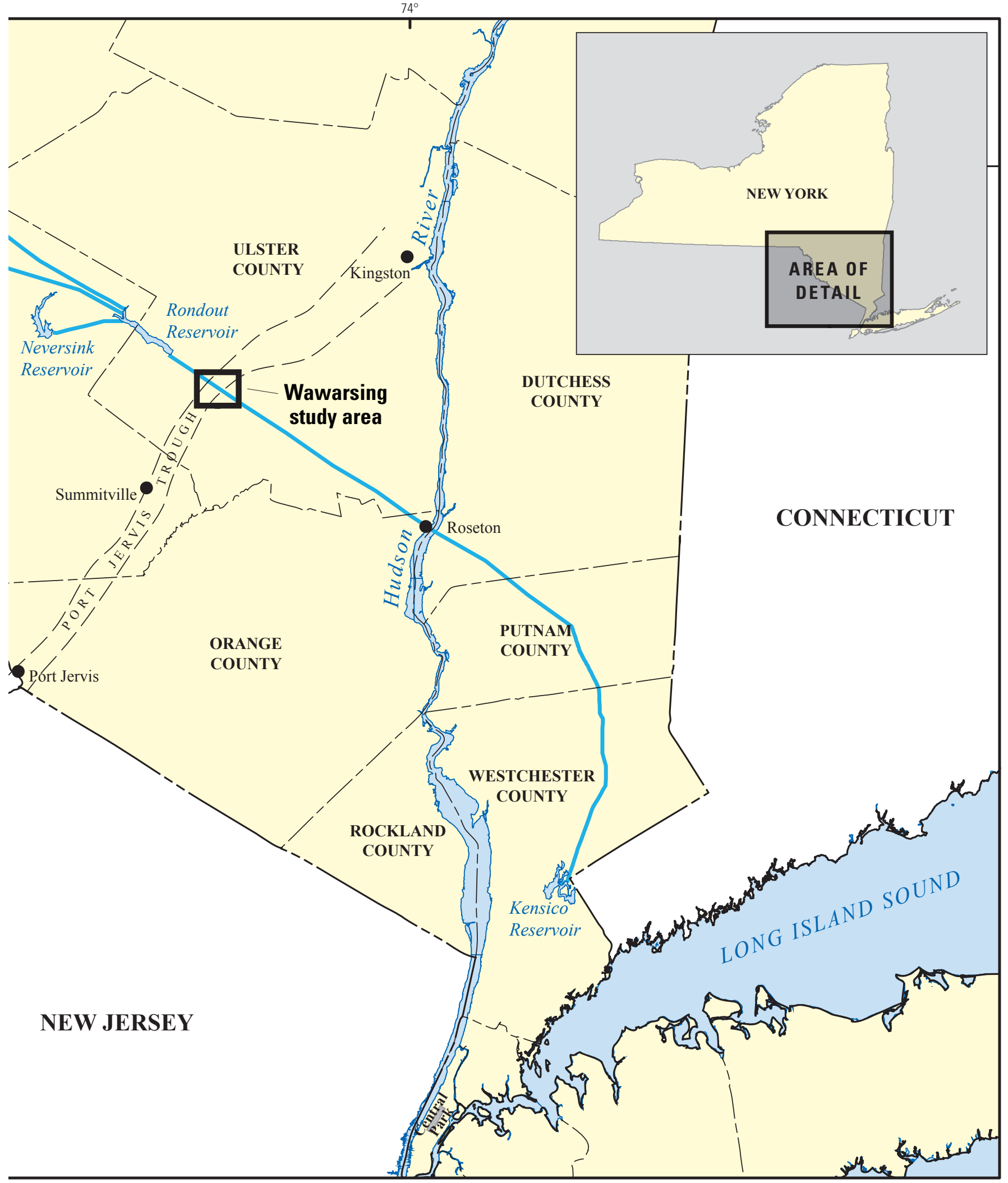

Figure 1. Location of Wawarsing study area including Summitville, Port Jervis Trough (Kingston to Port Jervis), the four reservoirs (Cannonsville, Pepacton, Neversink, and Rondout), the Delaware Aqueduct, and the Kensico Reservoir in New York.-Continued 
wells appears to be related to elevated water-table levels and the presence of clay in the shallow subsurface in some areas. Basement flooding is related to the local water-table elevation, its proximity to basement-floor elevations, and local variations in subsurface geology. To investigate the possible relation between basement flooding and leakage from the adjacent New York City Rondout-West Branch (RWB) Water Tunnel, the U.S. Geological Survey (USGS), in cooperation with the New York City Department of Environmental Protection (NYCDEP), began a study in the fall of 2008 to characterize the groundwater-flow system in the area. The study area within the town of Wawarsing is about 12 square miles $\left(\mathrm{mi}^{2}\right)$ and includes parts of the hamlets of Napanoch to the south and Kerhonkson to the north (fig. 2).

\section{Objectives and Approach}

The objective of the study was to characterize the groundwater-flow system of the study area, including an investigation of the hydrologic connection between the flow system and the RWB Tunnel.

The approach of the study included-

1. development of a groundwater-level monitoring network for the unconsolidated and bedrock aquifers;

2. monitoring of groundwater levels seasonally and during temporary RWB Tunnel shutdowns;

3. compilation of hydrogeologic data from RWB Tunnel construction and well drilling;

4. collection and analysis of geochemical isotope and agedating tracers in the groundwater and surface water, and

5. collection and analysis of surface and borehole geophysical surveys.

\section{Purpose and Scope}

This report (1) describes the hydrologic characteristics of the unconsolidated and bedrock aquifers in the study area; (2) compares the water-level elevations in the RWB Tunnel shaft during temporary shutdowns with measured groundwater elevations in observation, private-supply, and production wells; and (3) presents a preliminary analysis of the relation of water levels, amplitudes of water-level changes, and tunnelinfluence delay times in the well network to water levels in the RWB Tunnel shaft during temporary tunnel shutdowns.

\section{Previous Studies}

Several published reports describe the surficial and bedrock geology and hydrology of the area. Frimpter (1970, 1972) compiled well-drilling logs and described the unconsolidated deposits and bedrock in Orange and Ulster
Counties. Berkey (1911) described the unconsolidated deposits, bedrock, and possible faults in the Rondout Valley. Fluhr and Terenzio $(1973,1984)$ described the geologic results of exploration drilling and tunnel construction by the New York City Board of Water Supply (NYCBWS) in the study area. Caldwell (1989) mapped the surficial geology of the study area and Reynolds (2007) described the unconsolidated aquifers in the area. Fisher and others (1970) mapped the bedrock geology of the study area. Bartosik (2005) described the post-glacial history of the study-area valley. Berkey and Fluhr (1936), Dibbell (1944), and the New York City Board of Water Supply $(1940,1941)$ described the construction, geology, and hydrology of the RWB Tunnel in the study area. This data set was invaluable in understanding geologic contacts, faults, and groundwater inflow from the bedrock surrounding the tunnel.

\section{Rondout-West Branch Tunnel}

The RWB Tunnel delivers water from four interconnected reservoirs that constitute the Delaware System: the Cannonsville, Pepacton, Neversink, and Rondout Reservoirs (fig. 1). Separate tunnels from the Cannonsville, Pepacton, and Neversink Reservoirs deliver water to the Rondout Reservoir, which is then collected in the Rondout Reservoir and sent through the RWB Tunnel toward New York City. Construction of the RWB Tunnel portion of the Delaware System began in 1937 and was completed in 1944 (New York City Department of Environmental Protection, 2010; Merguerian, 2000). The reservoirs were built and put on line in stages, with the Rondout Reservoir being the first completed, in 1950. The Neversink, Pepacton, and Cannonsville Reservoirs were completed and added to the Delaware System in 1954, 1955, and 1964, respectively (New York City Department of Environmental Protection, 2010). The RWB Tunnel supplies roughly half of the 1.03 billion gallons of water per day delivered, on average, to New York City (New York City Department of Environmental Protection, 2010).

The RWB Tunnel underlies the central part of the study area at an average depth of $710 \mathrm{ft}$ below the valley floor. During the construction of the RWB Tunnel, groundwater inflows ranging from less than 1 to more than 9,000 gallons per minute ( $\mathrm{gal} / \mathrm{min}$ ) were found at fractures, fault zones, solution features, and geologic contacts beneath the study area (Dibbell, 1944; New York City Board of Water Supply, 1941) (figs. 3A and 3B). At least five faults were identified in the bedrock encountered beneath the study area. Sections of highly weathered rocks had been mechanically broken up, and crush zones and dissolution features were encountered. Steel reinforcements were required to stabilize the tunnel throughout most of the Rondout Valley. The excavated tunnel was lined with concrete to a $13.5-\mathrm{ft}$ finished diameter. More than 20,000 bags of concrete were needed to stabilize one section of the tunnel, where inflow exceeded 9,000 gal/min, during construction (New York City Board 
of Water Supply, 1941). In that part of the tunnel, a special reinforced section (steel interliner) was required (fig. 3A). Estimated leakage out of the RWB Tunnel is 15 to 35 million gallons per day (Mgal/d) (James Canale, New York City Department of Environmental Protection, written commun., 2011; DiNapoli, 2007) (fig. 1).

Flooded basements, unusual changes in the water levels in homeowners' wells, and new springs were first reported by Wawarsing residents in 1992. In 2003 and 2009, an autonomous underwater vehicle was used to inspect the interior of the RWB Tunnel. It recorded 8,200 linear feet of cracking throughout the tunnel (James Canale, New York City Department of Environmental Protection, written commun., 2011). Most of the cracking was found in the sections of the tunnel that are within the limestone units at Roseton and Wawarsing, N.Y.

Periodic construction, maintenance, and repairs of the tunnel infrastructure have required that flow through the tunnel be temporarily reduced or substantially lowered ("shutdowns") for short periods of time, during which residents have claimed to observe a reduction in basement flooding and lower water levels in private-supply wells. This report outlines the hydrologic response of groundwater in the unconsolidated and bedrock aquifers to four temporary shutdowns of the RWB Tunnel that occurred during October-December 2008, November 2009, December 2009, and January 2010.

\section{Precipitation}

The National Weather Service (NWS) has recorded daily precipitation since 1869 in Central Park in New York City (National Oceanic and Atmospheric Administration, 2010). The 141-year record indicates that the mean annual precipitation is 45.10 inches (in.) (fig. 4). Long-term precipitation records are available for the areas surrounding the study area, but the higher elevation (about 1,245 ft) of one site, gaps in data, and lack of long-term measurements at most sites reduce their applicability to the study area. Randall (1996) studied precipitation variations in upstate (northern) New York and found that the Wawarsing study area received an average of about 44 in. of precipitation annually from 1951 to 1980 . During this same period, precipitation in Central Park averaged 44.55 in. Comparing the Central Park data with the shorter records from nearby weather stations indicates only slight variations due to localized storms. The Central Park data were used in the hydrologic analysis in this study because of the high quality of the long-term records that correlate closely with the less extensive local data.

The annual precipitation in Central Park has exceeded the long-term mean every year from 2002 through 2010 (fig. 4). This is the first time in the 141-year record that annual precipitation has exceeded the annual mean for 9 consecutive years. During the same 9 years, many long-term precipitation records were broken. The NWS has determined the wettest years, months overall, months, seasons, and individual days for the Central Park weather station (fig. 4). The years 2007, 2006, and 2003 were the fourth wettest (61.70 in.), seventh wettest (59.90 in.), and eighth wettest (58.56 in.) years during the 141-year record, respectively. October 2005 and April 2007 were the second and fifth wettest months overall, respectively. February 2010 and 2008 were the third and tenth wettest Februarys, respectively. March 2010 and 2001 were the wettest and sixth wettest Marches, respectively. April 2007 was the second wettest April. April 15, 2007, was the second wettest day ever recorded for Central Park, with 7.57 in. of precipitation. June 2003, 2009, and 2006 were the wettest, second wettest, and sixth wettest Junes, respectively. September 2004 was the third wettest September recorded; October 2005 was the wettest October; and December 2009 and December 2008 were the fourth and eighth wettest Decembers, respectively.

The NWS defines spring as including March, April, and May; summer includes June, July, and August; fall includes September, October, and November; and winter includes December, January, and February. The spring of 2007; the summers of 2003, 2006, 2007, and 2009; the falls of 2005 and 2006; and winter 2009-10 were all among the 10 wettest seasons ever recorded in Central Park (National Oceanic and Atmospheric Administration, 2010).

These high precipitation values may be related to a change in climate, but their impact has been to increase water levels in the unconsolidated and bedrock aquifers and contribute to surface flooding when the rate of precipitation exceeds the rate at which the water can be drained away from roadways or can infiltrate into (recharge) surficial deposits in Wawarsing.

\section{Hydrogeology}

The study area consists of a relatively flat, glaciated valley with isolated kames and glacial-lake deltas that rise about $70 \mathrm{ft}$ above the surrounding valley floor (fig. 5). The Port Jervis Trough (fig. 1) is a deep, glaciated valley that extends about 100 miles southward from Kingston, N.Y. (Van Diver, 1989). In New York, the trough extends northward about $34 \mathrm{mi}$ from Port Jervis to Kerhonkson, and separates the Shawangunk Mountains to the east from the Catskill Front (eastern side of the Catskill Mountains) to the west (Reynolds, 2007). Both Soren (1961) and Frimpter (1972) reported that the outwash in the northern extension of this trough from the Orange-Sullivan County line northward to Summitville is much coarser than at Port Jervis (figs. 1 and 2). The valley slopes northward and contains thick deposits of lacustrine clay and silt as well as both unconfined and locally confined sand and gravel aquifers.

Sedimentary bedrock crops out and rises above the valley floor, forming a boundary along its eastern and western sides (fig. 5). The surrounding bedrock uplands rise about $150 \mathrm{ft}$ above the valley to the west and about $300 \mathrm{ft}$ to the east. The 


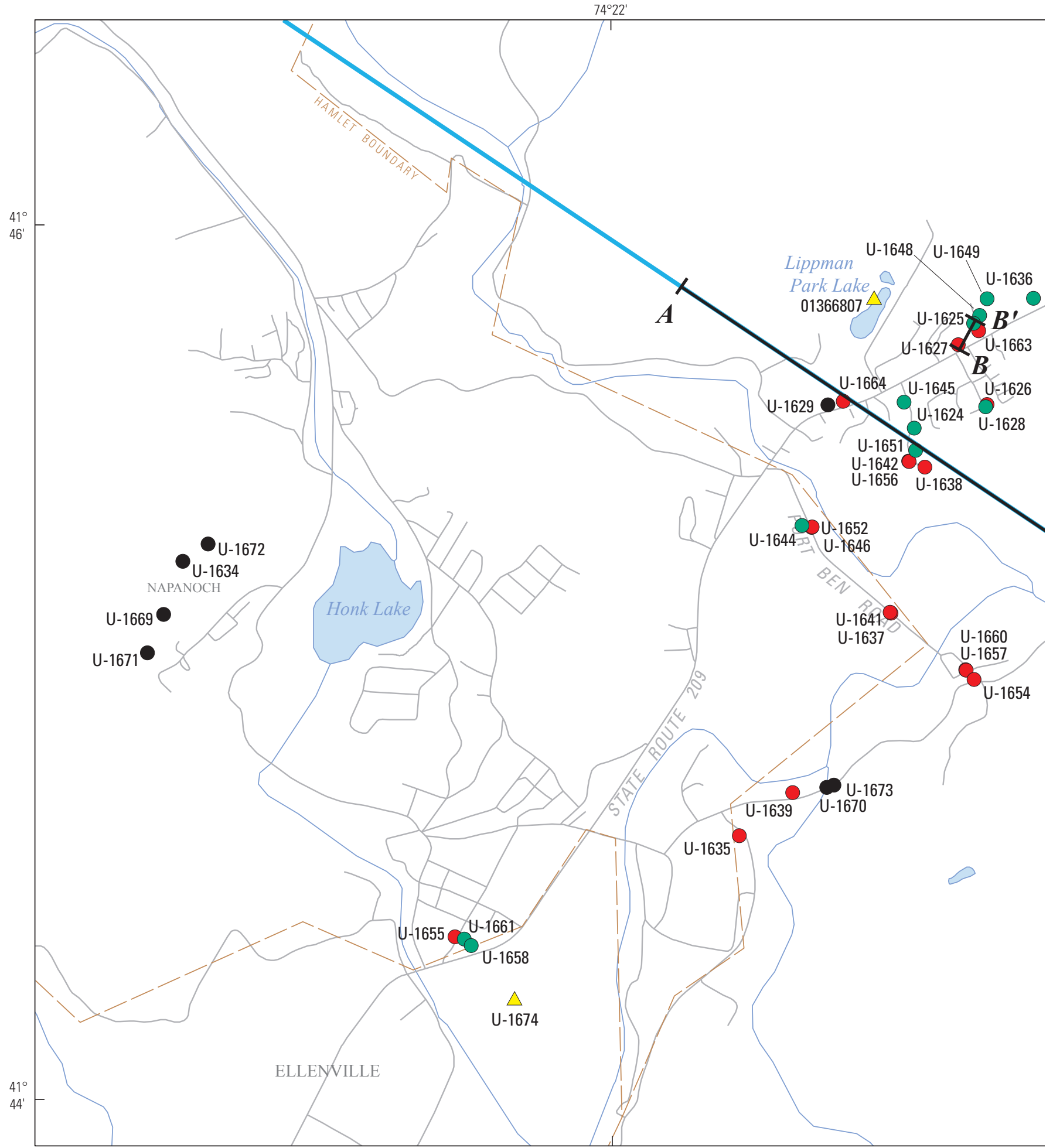

Base from U.S. Geological Survey Digital Data 1:100,000 series

Lambert Conformal Conic Projection

North American Datum of 1983

Figure 2. Locations of bedrock and unconsolidated-aquifer wells, production wells, and selected surface-water sites within the study area, Town of Wawarsing, Ulster County, New York. (For location map, see figure 1.) 


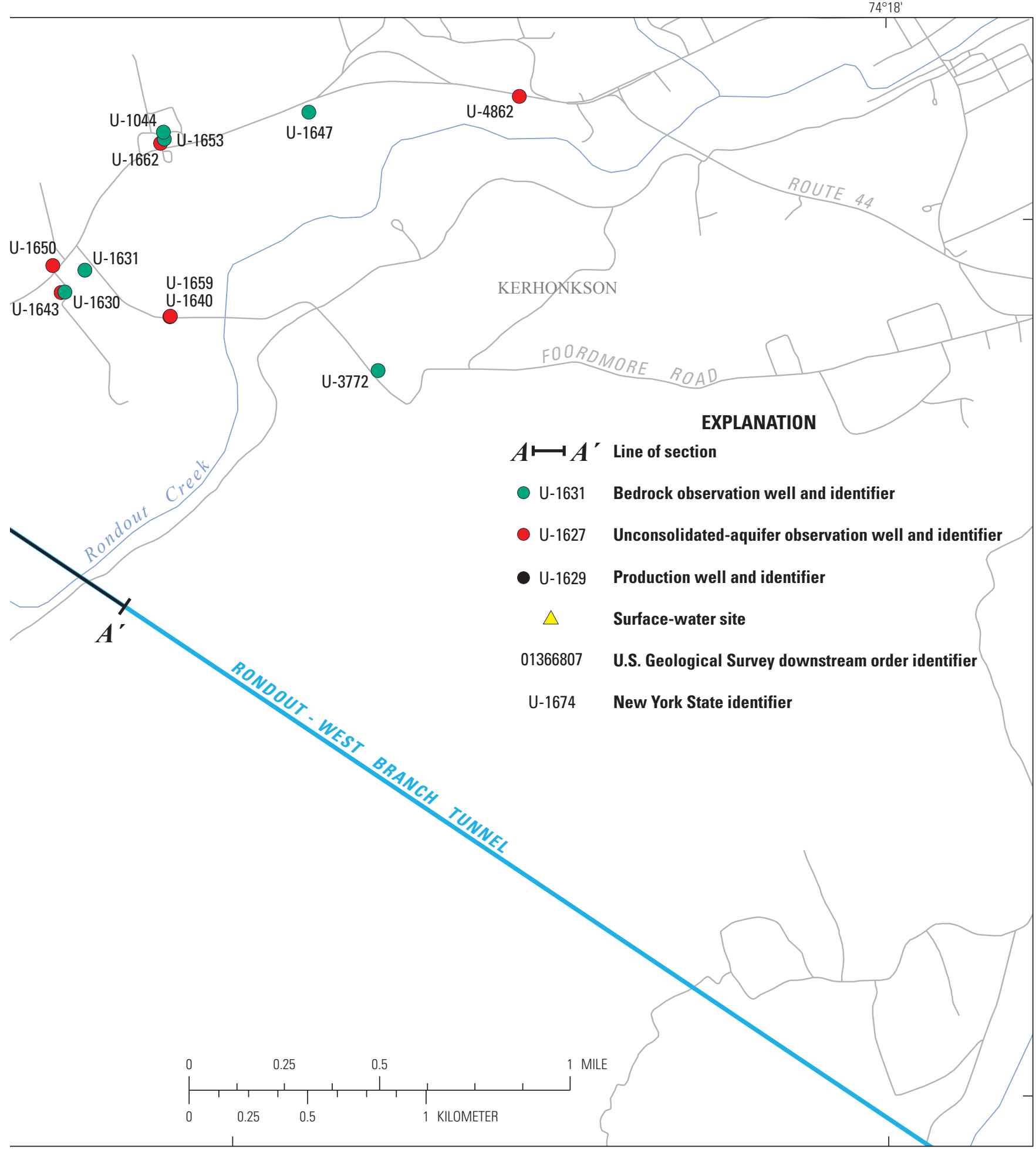

Figure 2. Locations of bedrock and unconsolidated-aquifer wells, production wells, and selected surface-water sites within the study area, Town of Wawarsing, Ulster County, New York. (For location map, see figure 1.)—Continued 


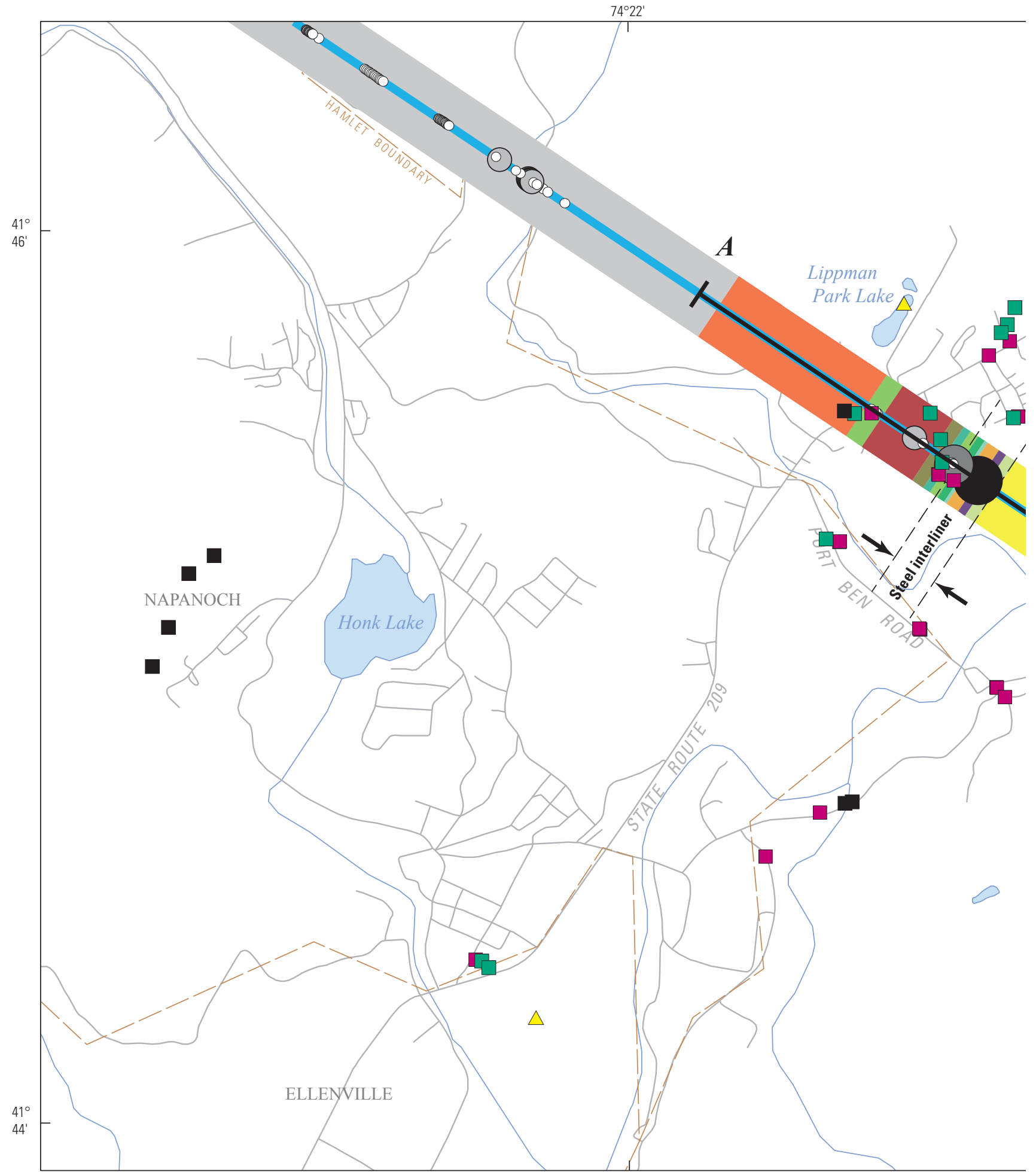

Base from U.S. Geological Survey Digital Data 1:100,000 series Lambert Conformal Conic Projection

North American Datum of 1983

Figure 3A. Locations of observation wells, production wells, and surface-water sites; Roundout-West Branch Tunnel geology; and water-inflow rates documented during tunnel construction within the study area, Town of Wawarsing, Ulster County, New York. (Tunnel geology and groundwater-inflow data from Dibbell, 1944) (For location map, see figure 1.) 


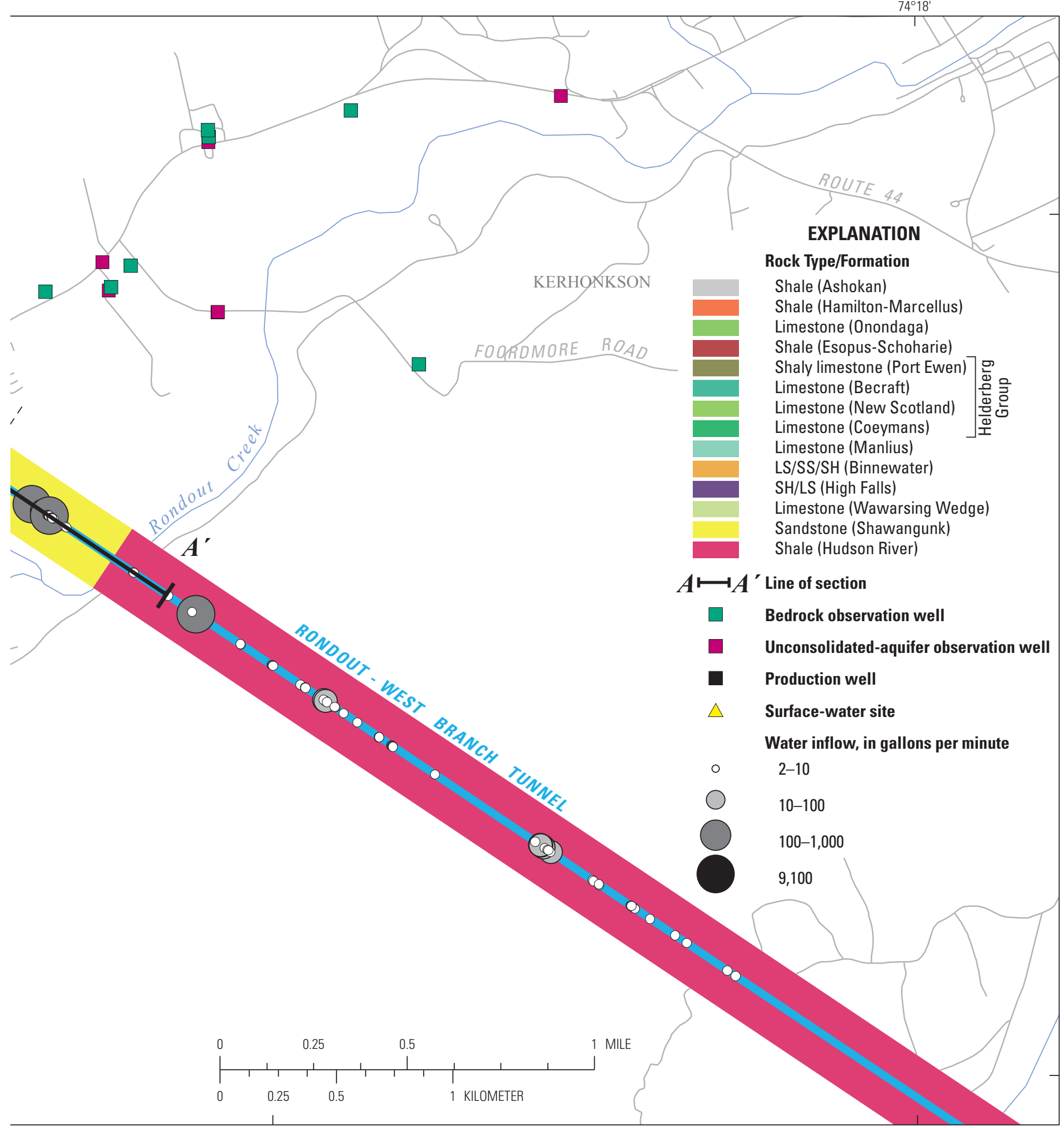

Figure 3A. Locations of observation wells, production wells, and surface-water sites; Roundout-West Branch Tunnel geology; and water-inflow rates documented during tunnel construction within the study area, Town of Wawarsing, Ulster County, New York. (Tunnel geology and groundwater-inflow data from Dibbell, 1944) (For location map, see figure 1.)—Continued 


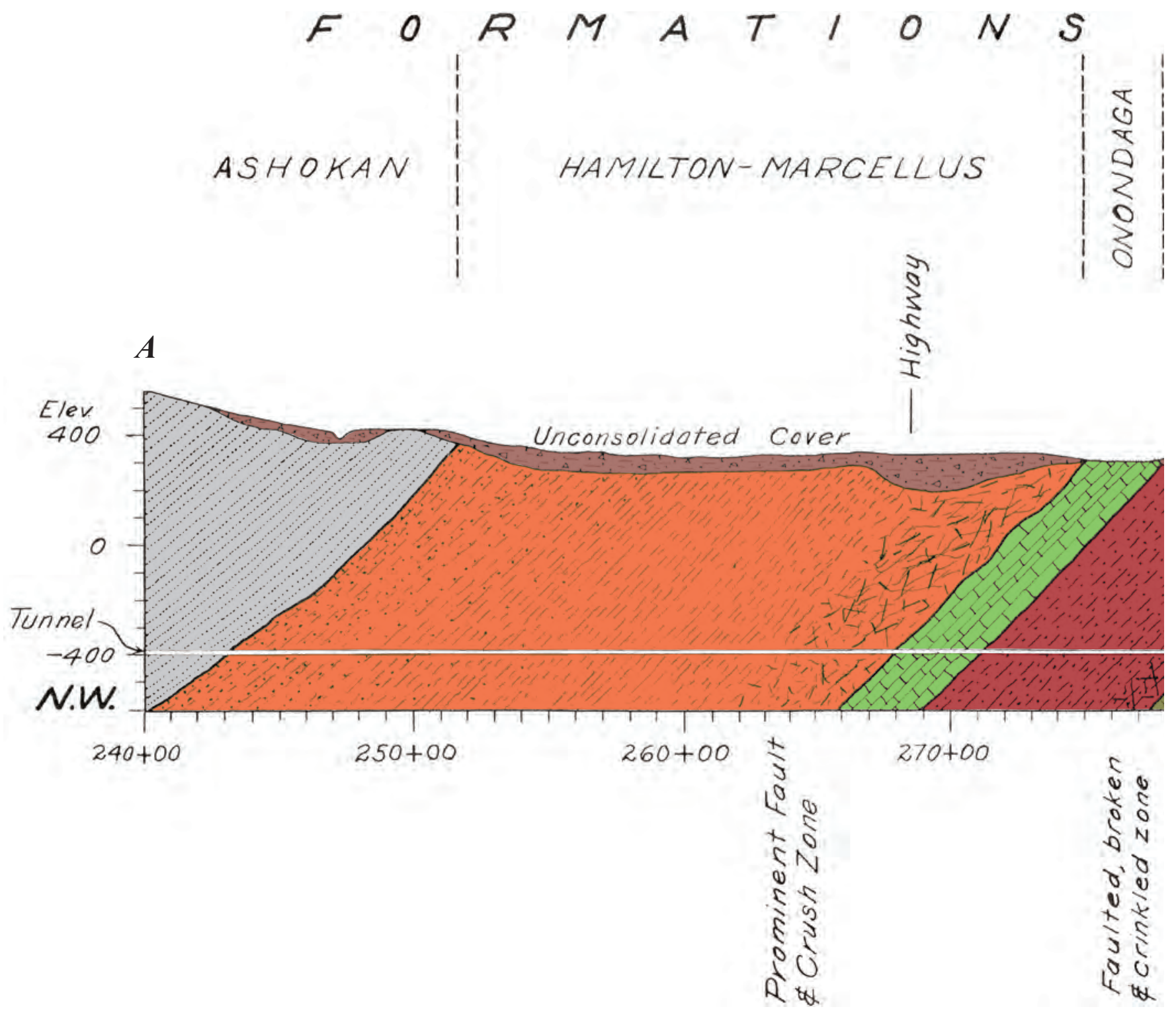

Figure 3B. Cross section of geology observed during New York City Board of Water Supply test borings and Rondout West-Branch Tunnel construction from A to A' within the study area, Town of Wawarsing, Ulster County, New York. (Location is shown in figure 3A.) (The Helderberg Group has been divided into the Port Ewen, Becraft, New Scotland, and Coeymans Formations.) (Modified from Berkey and Fluhr, 1936.) 

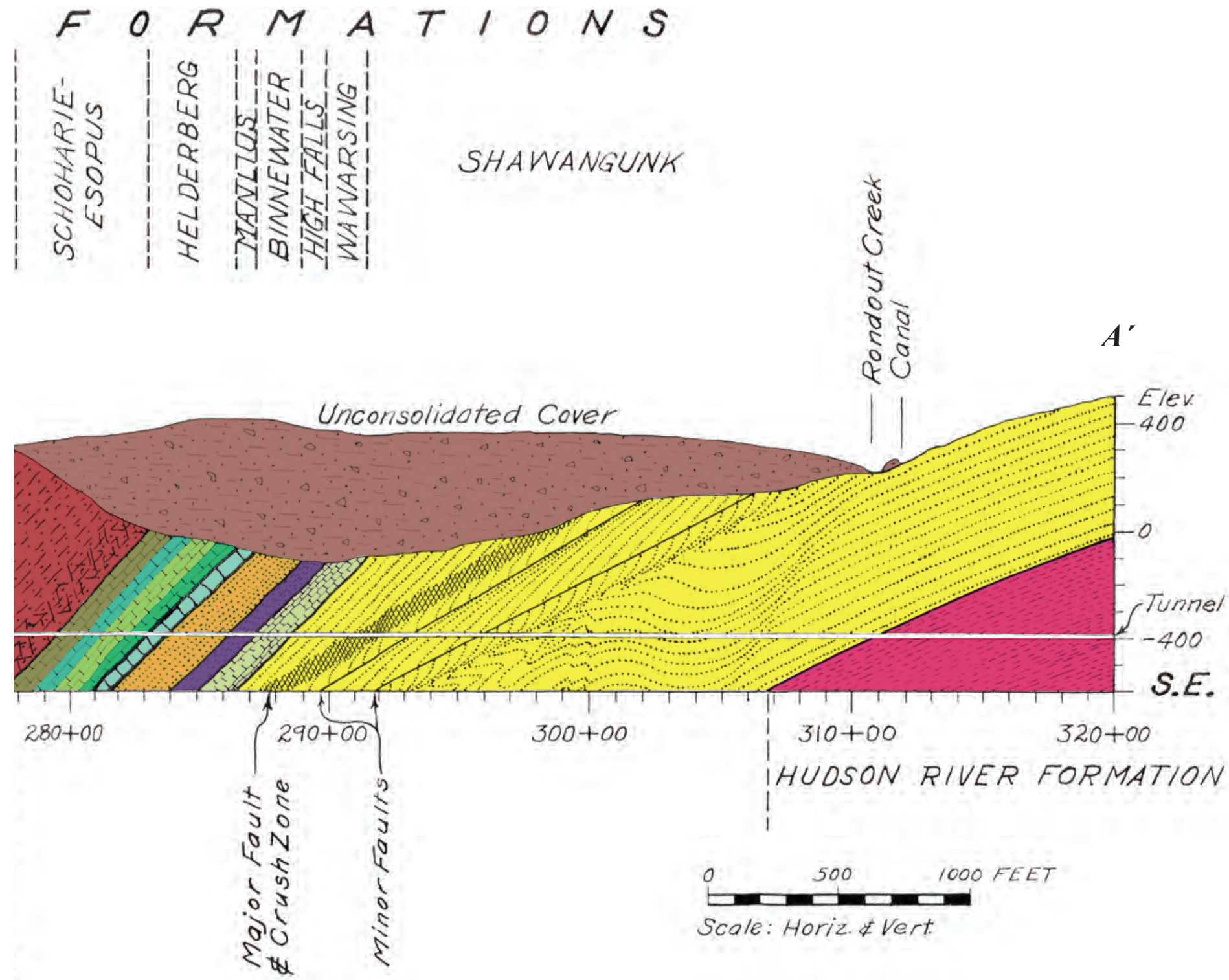

Figure 3B. Cross section of geology observed during New York City Board of Water Supply test borings and Rondout West-Branch Tunnel construction from A to A' within the study area, Town of Wawarsing, Ulster County, New York. (Location is shown in figure 3A.) (The Helderberg Group has been divided into the Port Ewen, Becraft, New Scotland, and Coeymans Formations.) (Modified from Berkey and Fluhr, 1936.).-Continued 


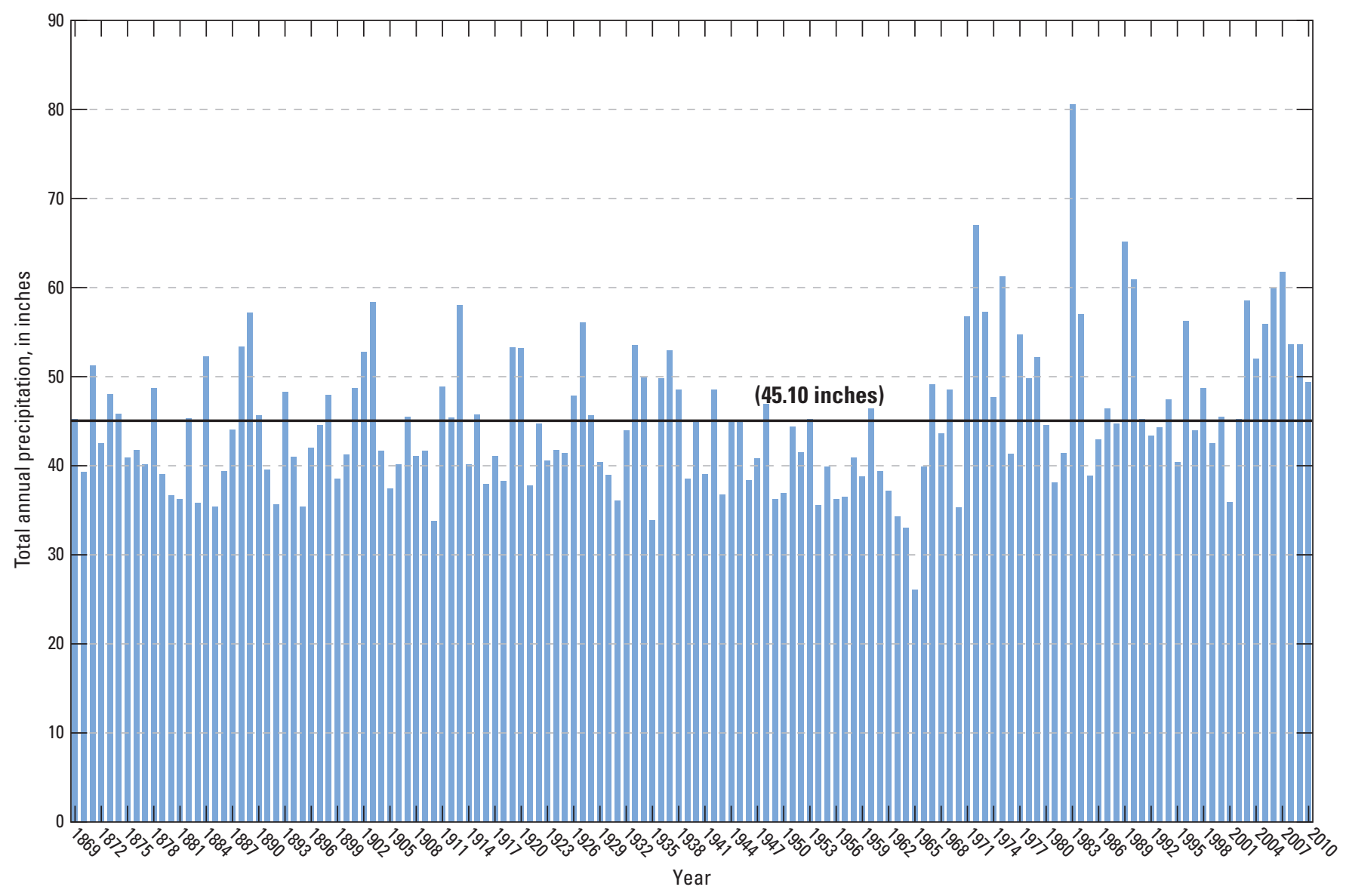

Figure 4. Annual precipitation as recorded by the National Weather Service at Central Park, New York County, New York, during 1869-2010 (National Oceanic and Atmospheric Administration, 2010). (Solid black line indicates annual mean precipitation during the 141-year period of observation.)

uplands have thin veneers of glacial and alluvial deposits with exposed bedrock outcrops. The valley is underlain by unconsolidated glacial deposits that vary in thickness from less than 10 to more than $300 \mathrm{ft}$.

\section{Unconsolidated Deposits}

The valley in the study area is underlain by gravel, sand, silt, and clay of Pleistocene and Holocene age. The unconsolidated deposits include till, lacustrine silt and clay, lacustrine delta sediments, kame and outwash sand and gravel, and alluvium (Cadwell, 1989). Frimpter (1972), Bartosik (2005), and Reynolds (2007) describe discontinuous sand and gravel aquifers buried beneath the glacial-lake sediments. Geologic data from 14 observation wells drilled by the USGS for this study indicate highly variable deposits ranging from sand and gravel to silt and clay. The lacustrine silt and clay locally exceed $140 \mathrm{ft}$ in thickness.

\section{Bedrock}

A complex series of sedimentary bedrock units of Silurian and Devonian age underlies the unconsolidated deposits in the study area (Fisher and others, 1970). In descending order as described by Berkey and Fluhr (1936), Dibbell (1944), and the New York City Board of Water Supply (1940), these include the Marcellus Shale, Onondaga Limestone, Esopus-Schoharie Shale, Helderberg Limestones (Port Ewen-Becraft, New Scotland, and Coeymans), Manlius Limestone, Binnewater Limestone and Sandstone, High Falls Shale and Limestone, Wawarsing Wedge complex, Shawangunk Sandstone, and Hudson River Shale. The Wawarsing Wedge, which consists mostly of limestone with minor shale and sandstone, pinches out to the north. The sedimentary bedrock units and their bedding generally strike northeast and dip about 45 degrees to the northwest (fig. 3B). Dibbell (1944) and the New York City Board of Water Supply (1940) describe the bedrock sequences 
below the study area as having sections with substantial fracturing and faulting. In limestone, dissolution along such secondary features and selected beds greatly increases aquifer transmissivity. Many of the bedrock flow zones produced volumes of groundwater in the range of thousands of gallons per minute in the study area during construction of the RWB Tunnel (fig. 3). In limestone, dissolution along such secondary features and selected beds greatly increases transmissivity in the direction of strike (northeast-southwest), resulting in an anisotropic aquifer in which transmissivity is much greater along the bedding strike than across it.

\section{Catskill Aqueduct Construction Observations}

During the exploration and construction of the Catskill Aqueduct about 10 miles (mi) northeast of the study area, nearly all of the bedrock units found in Wawarsing were encountered except the Wawarsing Wedge (Berkey, 1911). Caves and cavities filled with clay were discovered in test borings for the Catskill Aqueduct (Fluhr and Terenzio, 1973). During exploration drilling, a void $28 \mathrm{ft}$ in length was detected $200 \mathrm{ft}$ below land surface (Berkey, 1911). The Onondaga Limestone was described as being cavernous in many places, and members of the Helderberg and Manlius Limestones exhibited a tendency to develop cavernous structures (Berkey and Fluhr, 1936). In the Manlius Limestone, the most characteristic features were solution joints that in some places enlarged to cave-like form (Berkey, 1911). Several clay-filled spaces several feet wide were encountered during construction at about the -100-ft elevation (Berkey, 1911). The Binnewater Sandstone and the High Falls Shale were found to be more porous and transmissive than other formations in the area, especially along bedding planes (Berkey, 1911; Berkey and Fluhr, 1936). During construction of the aqueduct, vertical and horizontal clay-filled cavities and joints were encountered over a 500 -ft zone in the Helderberg Limestone (Fluhr and Terenzio, 1973). Several vertical chimneys or caves several feet wide crossed the tunnel at a 45-degree angle and extended high into the roof of the tunnel (Fluhr and Terenzio, 1973).

\section{Rondout West-Branch Water Tunnel Construction Observations}

The Catskill Aqueduct served as an indicator of what might be expected in the RWB Tunnel (Fluhr and Terenzio, 1973). The major difficulties in construction of the tunnel occurred over a $500-\mathrm{ft}$ section between the Helderberg Limestone and the Shawangunk Formation (Fluhr and Terenzio, 1973). Grouting proved unsuccessful in stopping inflows of groundwater from the Manlius Limestone (Fluhr and Terenzio, 1973). Several severely decayed bands with solution cavities produced large quantities of water (more than 9,000 gal $/ \mathrm{min}$ ) in the Binnewater Sandstone and the High Falls Shale (Dibbell, 1944; Fluhr and Terenzio, 1973; New
York City Board of Water Supply, 1940 and 1941). Many solution cavities, decayed or leached limestone, fault crush zones, and prominent solution features were described during construction of the steel interliner for the tunnel (Dibbell, 1944; New York City Board of Water Supply, 1940). The steel interliner was required within parts of the Manlius, Binnewater, High Falls, Wawarsing, and Shawangunk Formations (Dibbell, 1944; New York City Board of Water Supply, 1941) (fig. 2). Berkey (1911) states that formations that are porous or soluble and are subject to enforced seepage (from a pressurized tunnel) may become progressively more porous with time due to tunnel leakage. He describes blocks of the Manlius and Coeymans Limestones used in the Delaware and Hudson Canal that exhibited dissolution etching up to $1 \mathrm{in}$. deep resulting from contact with surface waters after only 35 to 40 years (Berkey, 1911). On the basis of the geologic core, the geologic descriptions of the tunnel excavation, and the large groundwater inflows, the bedrock within the study area can be highly transmissive locally as a result of a combination of fault crush zones, large fractures, and large dissolution features or cavities in some areas. The limestone bedrock demonstrates a potential for dissolution from leaking tunnel water (acidic surface water) without the normal buffering effects that reduce the acidity and dissolution potential of water recharged under natural conditions.

Water from the RWB Tunnel appears to be leaking from cracks in the concrete liner installed during construction in 1937-44. The cracks may allow pressurized tunnel water to flow behind and (or) through the liner where voids may exist and into the transmissive solution cavities in limestone, fractures, faults, and geologic contacts. Sustained leakage of pressurized tunnel water through limestone that has been subject to dissolution may further enhance the transmissivity of the limestone as a result of additional dissolution surrounding the tunnel liner.

\section{Hydrology}

In October 2008, the USGS began measuring groundwater levels in two private-supply unconsolidatedaquifer wells and in two bedrock wells (one private-supply and one production well). By July 2010, the groundwatermonitoring network had been expanded to 41 wells and 2 surface-water sites. Of the 41 wells, 23 are screened in unconsolidated deposits and 18 are cased through the unconsolidated deposits and completed as an open hole in bedrock. Water levels measured in the bedrock wells represent composite hydraulic heads and are largely controlled by the most transmissive zones. The two surface-water sites consist of a lake-level gage at the northwestern part of the lake at Lippman Park (USGS lake-level gage 01366807), and a possible limestone sinkhole (pond-level gage) located in an open field (U-1674) (fig. 2; table 1). 


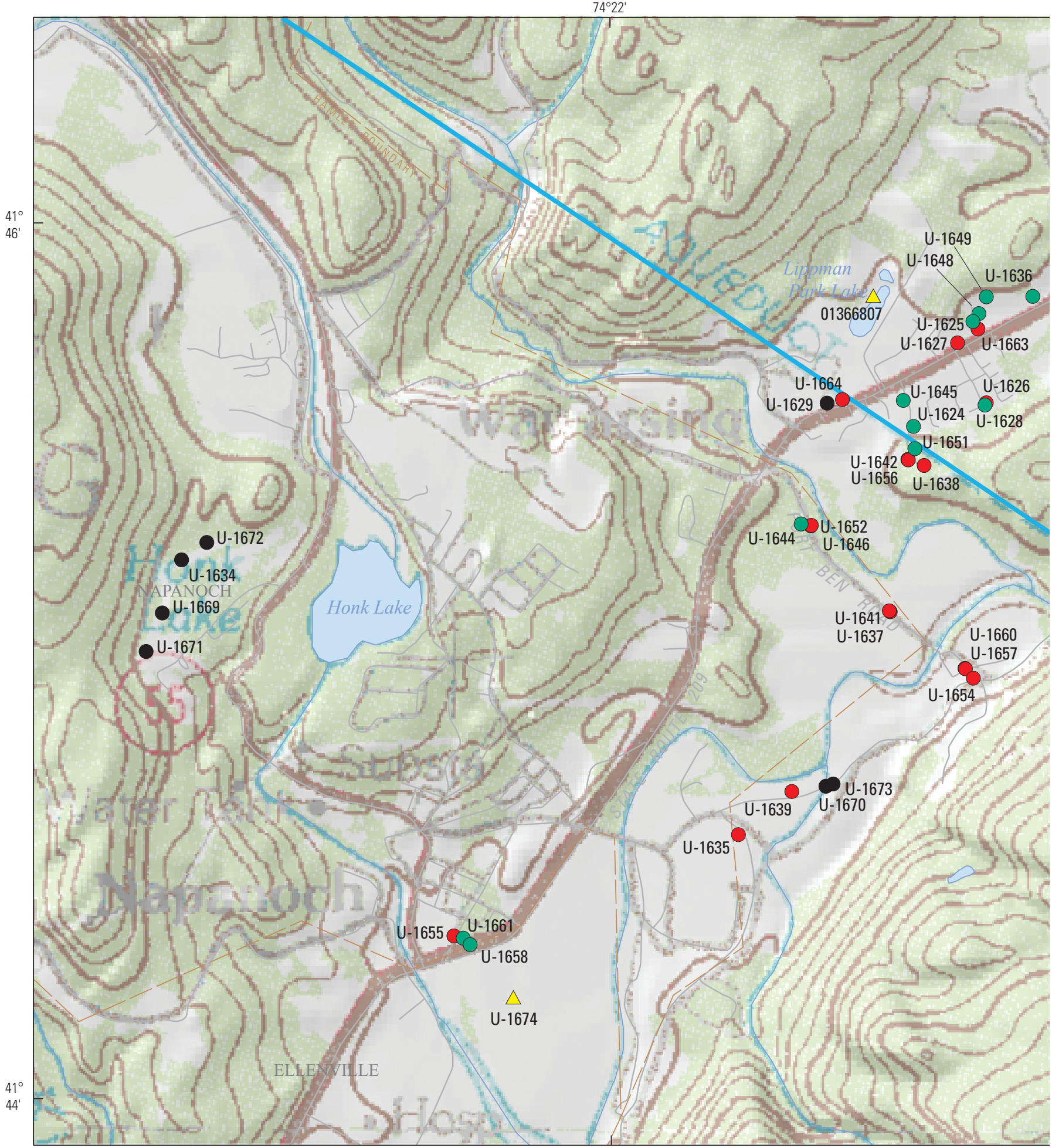

Base from U.S. Geological Survey Digital Data 1:100,000 series Lambert Conformal Conic Projection North American Datum of 1927

Figure 5. Topography and locations of bedrock and unconsolidated-aquifer observation wells, production wells, and selected surface-water sites within the study area, Town of Wawarsing, Ulster County, New York. 


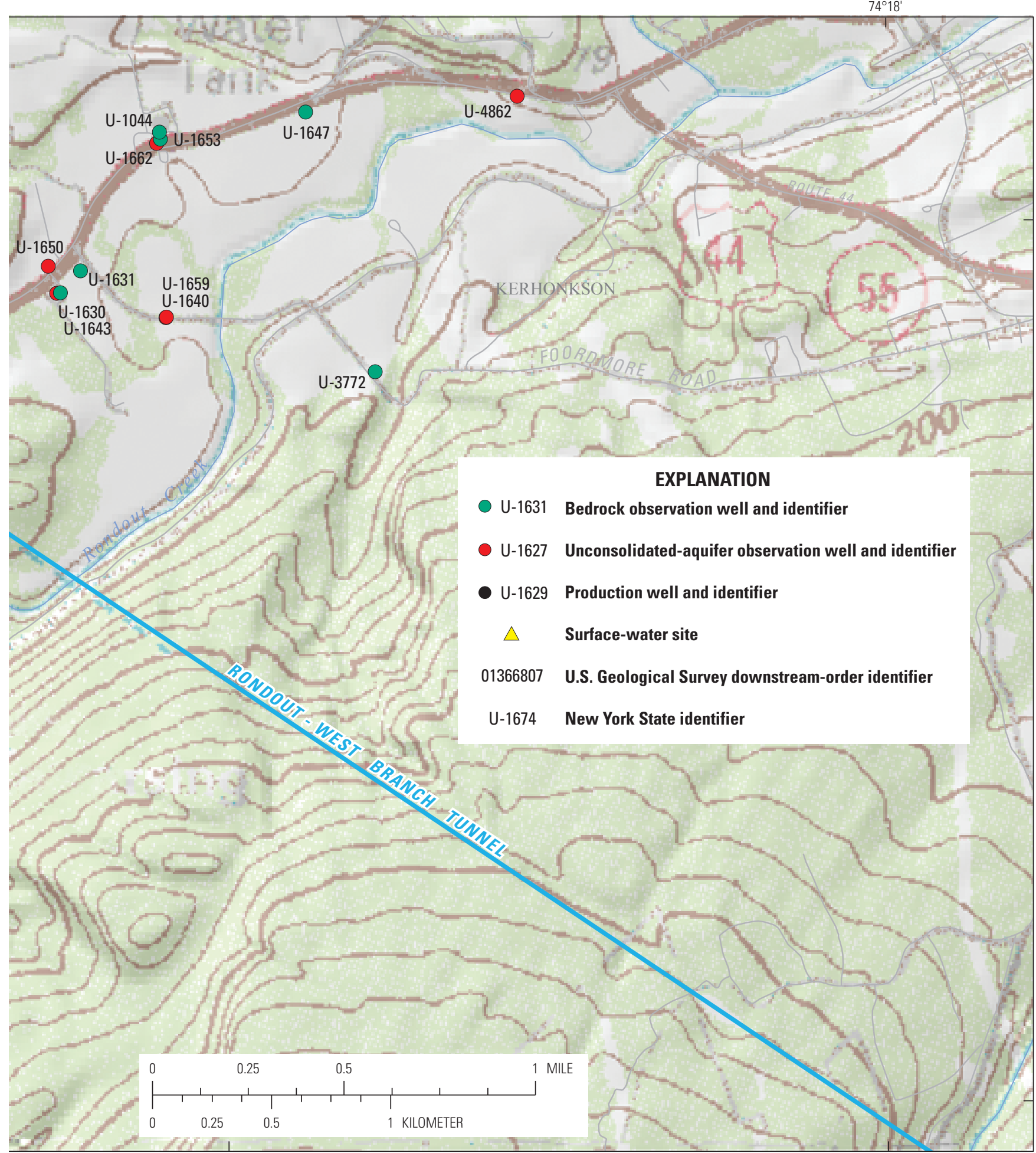

Figure 5. Topography and locations of bedrock and unconsolidated-aquifer observation wells, production wells, and selected surface-water sites within the study area, Town of Wawarsing, Ulster County, New York.-Continued 
Table 1. Site information for groundwater wells and selected surface-water sites within the study area, Town of Wawarsing, Ulster County, New York.

[NYSDEC, New York State Department of Environmental Conservation; USGS, U.S. Geological Survey; NAVD 88, North American Vertical Datum of 1988; NA, not applicable; ',',", degrees, minutes, seconds; --, no data]

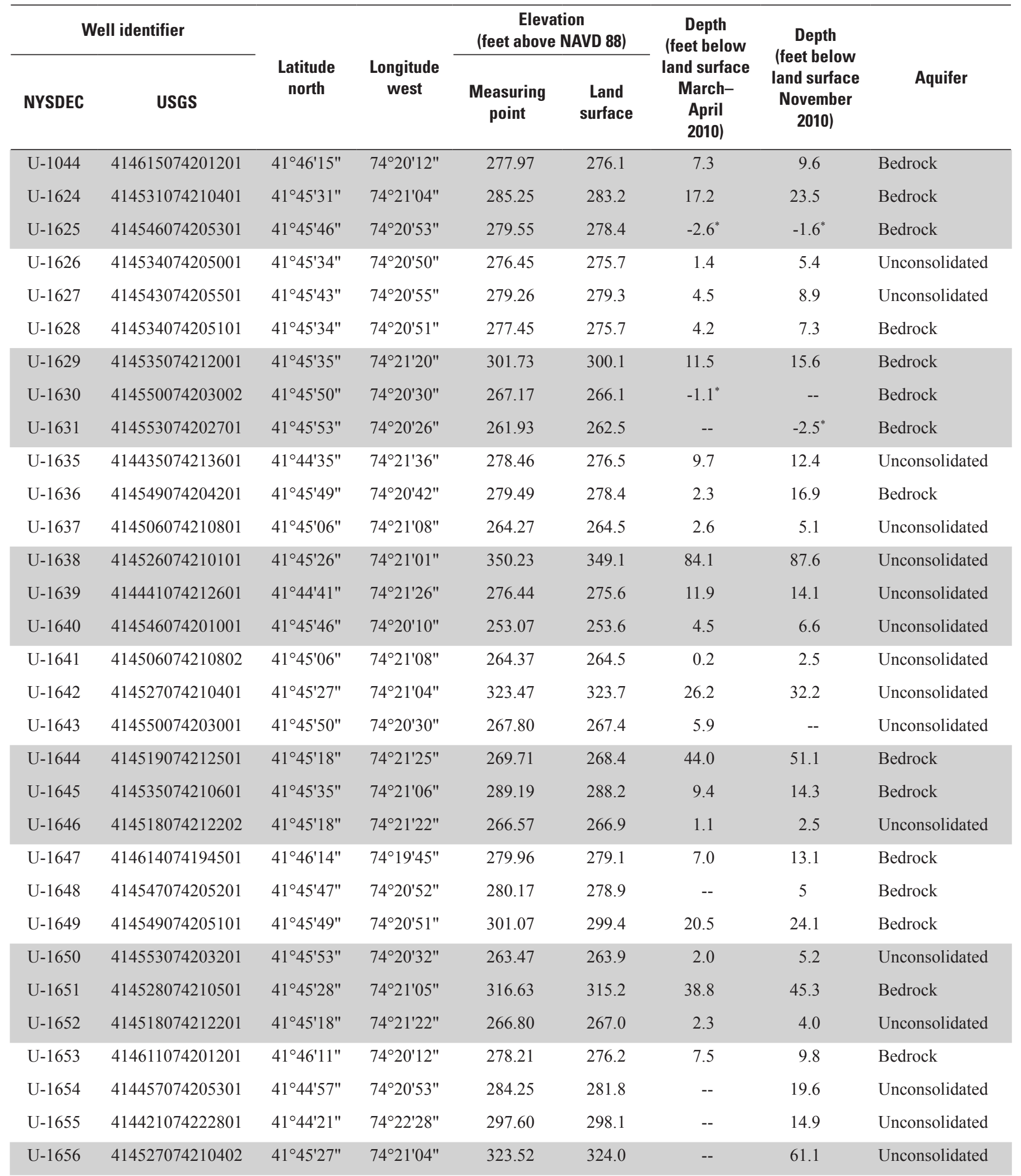


Table 1. Site information for groundwater wells and selected surface-water sites within the study area, Town of Wawarsing, Ulster County, New York.-Continued

[NYSDEC, New York State Department of Environmental Conservation; USGS, U.S. Geological Survey; NAVD 88, North American Vertical Datum of 1988; NA, not applicable; ',',", degrees, minutes, seconds; --, no data]

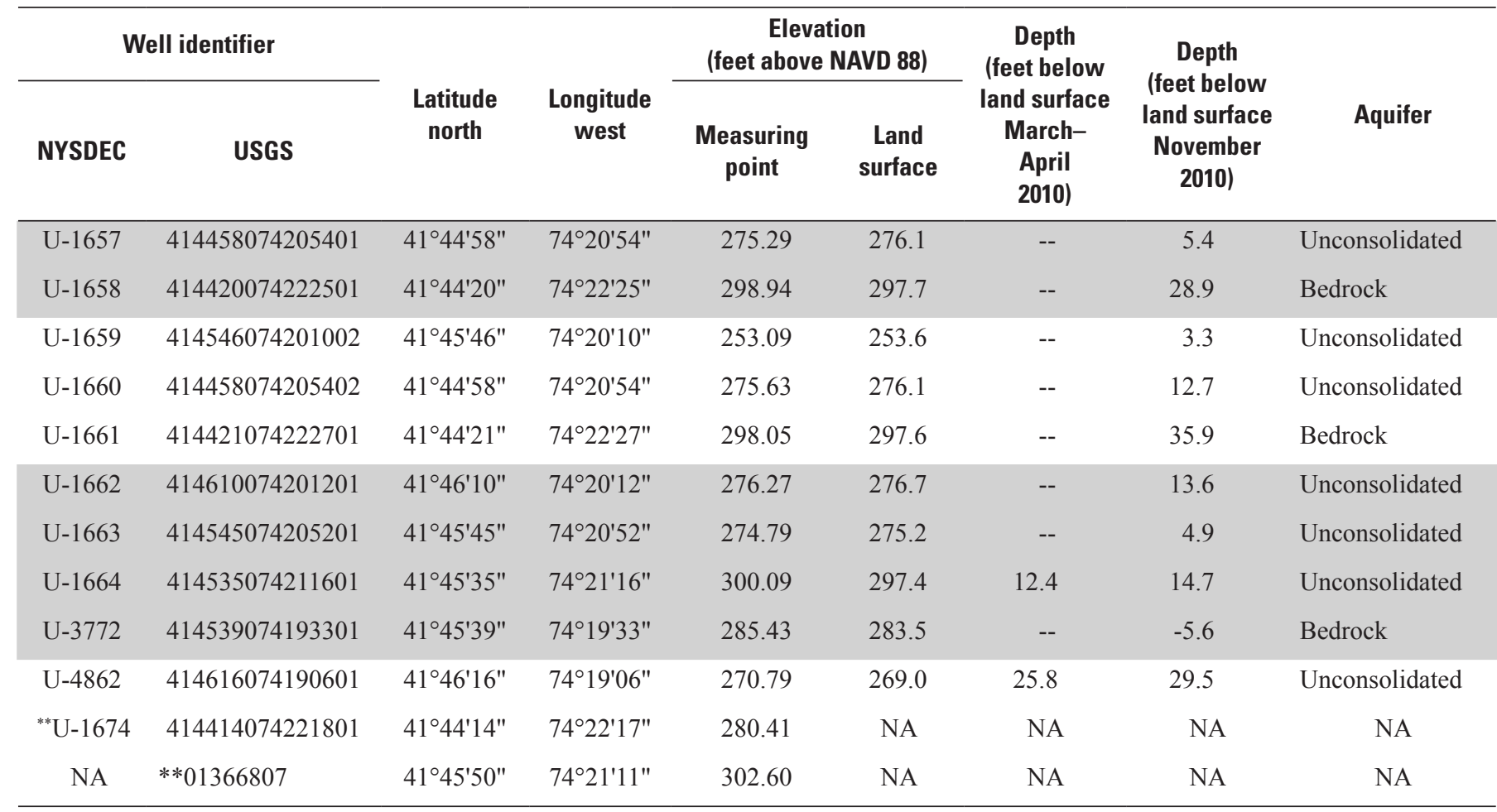

"Estimated.

${ }^{* *}$ Surface-water site.

\section{Groundwater-Flow System}

Major users of municipal water in the study area include the Village of Ellenville (4,323), Eastern/Ulster Correctional Facility (3,000), Kerhonkson Water District (500), Napanoch Water District (400), and various small private suppliers (811), totaling about 9,000 municipal groundwater users (New York State Department of Health, 1982). U.S. Census data in 2010 indicate that the total population of the Town of Wawarsing is 13,157 (United States Census Bureau, 2010). Within the study area, most households rely on individual private-supply wells in either the unconsolidated or bedrock aquifers. The transmissivity of the unconsolidated aquifer near Ellenville appears to be very high, as evidenced by a yield of $1,000 \mathrm{gal} / \mathrm{min}$ during test pumping of a 39 -ft-deep production well for the Village of Ellenville (Frimpter, 1972).

Manual measurements of groundwater levels were completed monthly. Precision global positioning system (GPS) surveying was used to establish benchmarks in the study area and to measure the elevations of monitored wells. Nearby wells and doublets were optically leveled and tied into the GPS elevations to within $0.003 \mathrm{ft}$. Hydraulic heads and vertical gradients for the measured wells were calculated using these precision elevations. Of the 41 wells, 29 are equipped with digital data loggers with pressure transducers that record groundwater levels and temperature hourly. Sixteen data loggers are in the unconsolidated-aquifer wells and 13 are in bedrock wells (fig. 2); one of these recorders is an electromagnetic flowmeter and pressure transducer that measures the discharge from flowing artesian bedrock well U-1631 (hydraulic head in this well is above the top of the well) in gallons per minute at hourly intervals (fig. 2). The well discharges groundwater at an average rate of $70 \mathrm{gal} / \mathrm{min}$, which is directed by a 4-in.-diameter pipe toward the front of the private property to a ditch along the nearby roadway.

\section{Long-Term Water-Level Monitoring}

At three wells (U-1626, U-1627, and U-1629) and a lakelevel gage (01366807), water levels were measured manually at monthly intervals and digitally at hourly intervals beginning in October/November 2008 (fig. 6). The lake-level gage is located in the northwestern part of a modified body of water called Lippman Lake, which receives runoff and base flow from several small streams that flow from the adjacent hills. Runoff from the lake discharges to a culvert when the lake level is high (fig. 2). Wells U-1626 and U-1627 are shallow 

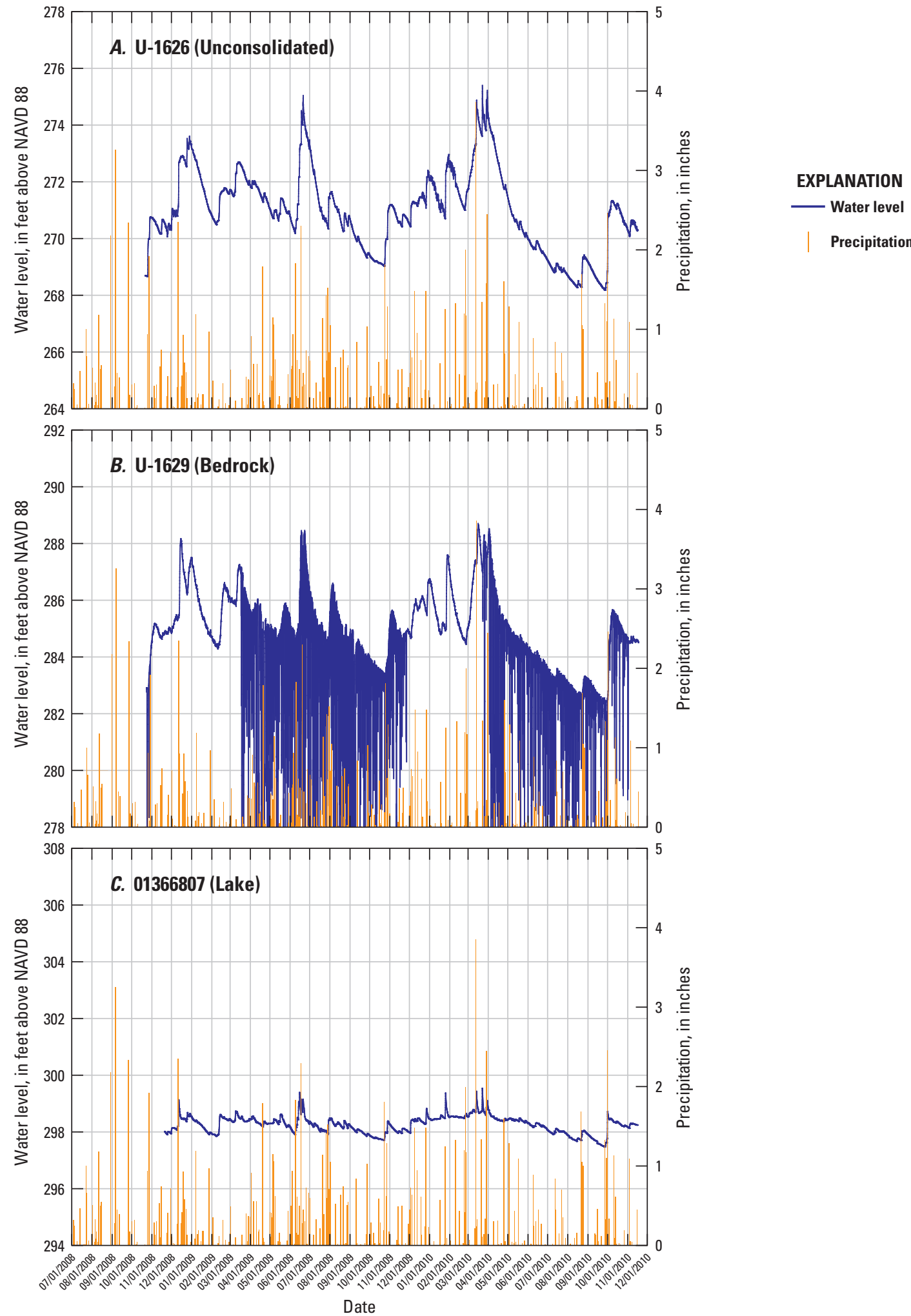

Figure 6. Water-level and precipitation data for three unconsolidated-aquifer wells, two bedrock wells, and a surface-water site within the study area, Town of Wawarsing, Ulster County, New York: $A$, Unconsolidated-aquifer well U-1626, October 21, 2008-November 16, 2010; $B$, bedrock production well U-1629, October 22, 2008-November 16, 2010; $C$, surface-water site at U.S Geological Survey lake gage 01366807, November 20, 2008-November 16, 2010; $D$, unconsolidated-aquifer well U-1627, October 21, 2008-December 1, 2010; $E$, unconsolidated-aquifer well U-1642, September 14, 2009-June 22, 2010; and F, bedrock well U-1628, February 24, 2009-December 1, 2010. (Precipitation data from National Oceanic and Atmospheric Administration station in Central Park, N.Y.; for locations, see figure 1). 

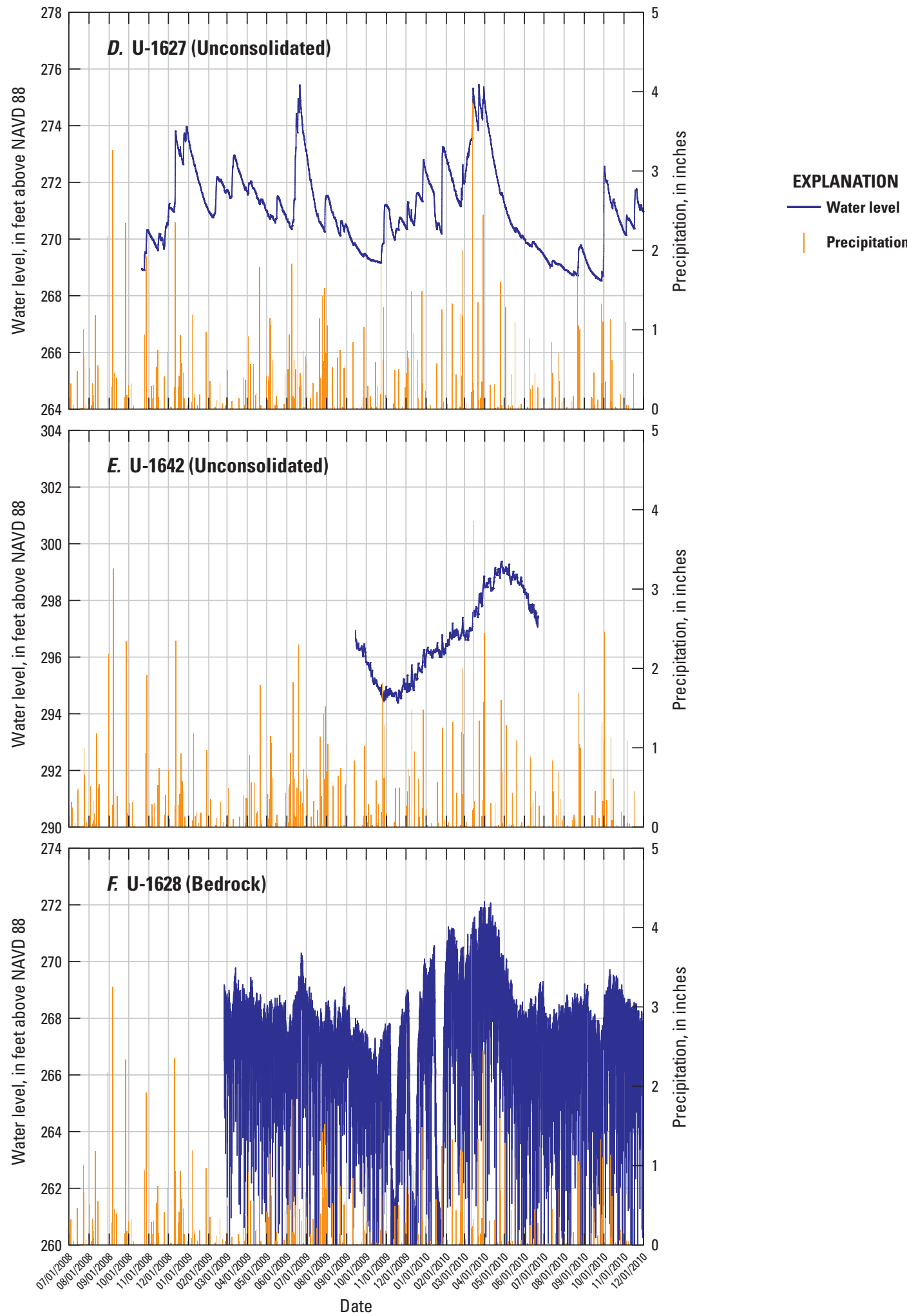

Figure 6. Water-level and precipitation data for three unconsolidated-aquifer wells, two bedrock wells, and a surface-water site within the study area, Town of Wawarsing, Ulster County, New York: A, Unconsolidated-aquifer well U-1626, October 21, 2008-November 16, 2010; $B$, bedrock production well U-1629, October 22, 2008-November 16, 2010; C, surface-water site at U.S Geological Survey lake gage 01366807, November 20, 2008-November 16, 2010; D, unconsolidated-aquifer well U-1627, October 21, 2008-December 1, 2010; $E$, unconsolidated-aquifer well U-1642, September 14, 2009-June 22, 2010; and $F$, bedrock well U-1628, February 24, 2009-December 1, 2010. (Precipitation data from National Oceanic and Atmospheric Administration station in Central Park, N.Y.; for locations, see figure 1).-Continued 
(10-ft-deep) dug wells in the unconsolidated aquifer (figs. 2 and 6). Well U-1629 is a 118-ft-deep production well open to bedrock (figs. 2 and 6). Well U-1629 is pumped during late March through mid-November but is not pumped during the winter (fig. 6). Drawdown in well U-1629 due to pumping can exceed $12 \mathrm{ft}$, below the depth of the digital recorder (fig. 6). Seasonal variations in the bedrock water levels are monitored during the recovery peaks. Hydrographs of wells screened in the unconsolidated aquifer (U-1626, U-1627, and U-1642), the bedrock aquifer (U-1628 and U-1629), and the lake-level gage indicate fluctuations in the water levels throughout the study period (October 2008-November 2010) (fig. 6).

In general, during the study period water levels were highest in two time periods - (1) March, April, and May, and (2) December and January (fig. 6.). During these periods, snow melt and elevated precipitation coupled with minimal evapotranspiration recharge the aquifers and raise the lake level. March 2010 was the wettest March recorded at the Central Park weather station since 1869 (National Oceanic and Atmospheric Administration, 2010). In June 2009, however, unusually high water levels were recorded in many of the network wells, producing an outlier in the seasonal waterlevel patterns (fig. 6). The high water levels were caused by the extremely large amount of precipitation measured in June 2009, one of the 10 wettest Junes since 1869 (National Oceanic and Atmospheric Administration, 2010). Water levels typically are lowest in August, September, and October (fig. 6). The hydrographs indicate discharge from the aquifers due to reduced precipitation, increased consumptive use, and increased evapotranspiration from the aquifers (seasonal effects). Water levels in both the unconsolidated-aquifer and bedrock wells are closely correlated with precipitation (fig. 6). The large influence of precipitation on groundwater levels in the study area can be seen in long-term hydrographs (fig. 6). Punctuated shutdowns of the RWB Tunnel revealed that leakage from the tunnel affected the aquifers both regionally and locally, as discussed in detail farther on in this report.

The hydrograph of well U-1642, a USGS observation well screened in the unconsolidated aquifer, was an exception to these patterns, however (fig. 6). The localized mounding of groundwater due to the presence of unique geologic deposits in that area is described in detail farther on in this report.

In the unconsolidated aquifer, variations in precipitation and seasonal effects caused water levels to range seasonally from $3.5 \mathrm{ft}$ (in well U-1652) to $6.5 \mathrm{ft}$ (in well U-1626) (figs. 2 and 6). On average, water levels in the unconsolidated aquifer had a seasonal difference of $5 \mathrm{ft}$ (fig. 7). Seasonal differences in water levels in wells in the bedrock aquifer ranged from $1.5 \mathrm{ft}$ (in well U-3772) to $9.5 \mathrm{ft}$ (in well U-1645) (fig. 2). On average, water levels in the bedrock aquifer had a seasonal difference of $5.3 \mathrm{ft}$ (fig. 6).

In general, groundwater flows through a network of interconnected fractures in bedrock from higher elevations in the surrounding hills toward the center of the valley. The unconsolidated aquifer receives recharge as a result of infiltration throughout the valley. Water levels in Lippman
Lake responded similarly to precipitation changes, but with smaller amplitudes (fig. 6). Field observations and survey measurements indicate that overflow of the lake to a culvert is minimal and occurs only when the lake stage exceeds an elevation of $298.2 \mathrm{ft}$. Water levels in nearby unconsolidatedaquifer wells indicate that recharge (subsurface leakage) from the lake to the shallow aquifers occurs locally throughout the year.

\section{Potentiometric Surface in the Bedrock Aquifer}

Most of the recharge to the bedrock aquifer probably occurs through outcrops of fractured bedrock at the higher elevations in the hills that surround the study-area valley. In some bedrock wells the potentiometric surface was higher than the top of the well casing, resulting in flowing artesian conditions (fig. 7). Results of a synoptic measurement in March/April 2010 indicate that the elevation of the potentiometric surface of the bedrock aquifer ranges from $288.6 \mathrm{ft}$ (11.5 ft below land surface (BLS)) at well U-1629, along the base of the surrounding hills on the west side of the valley, to $267.2 \mathrm{ft}$ (-1.1 ft BLS (flowing artesian well)) at well U-1630 in the north-central part of the valley (fig. 8). An exception was a cone of depression at well U-1644, where water-level elevations were only $224.4 \mathrm{ft}$ (44.0 ft BLS), probably as a result of pumping from a low-transmissivity bedrock unit, possibly the Esopus Shale. Similar conditions were measured at this well in November 2010, but water levels were slightly lower (fig. 9).

In November 2010, an anomaly in groundwater-elevation contours was observed along Route 209 near wells U-1651, U-1628, and U-1625 (a flowing artesian well) (fig. 9). Higher water levels in these wells are indicated by comparing the local changes in contour lines to those in the regional trend.

In November 2010, the head differential between wells U-1629 (in bedrock) and U-1664 (in the unconsolidated aquifer) was upward at $1.8 \mathrm{ft}$. This was the smallest head differential measured in any bedrock/unconsolidated-aquifer doublet. Upward flow gradients of 9.7, 6.8, 2.8, 5.1, 7.0, and $3.3 \mathrm{ft}$ were measured at wells U-1625, U-1630, U-1636, U-1649, U-1651, and U-1653, respectively (figs. 7, 8, and 9). With the exception of one doublet, flow gradients from the bedrock to the unconsolidated aquifers at all bedrock wells influenced by tunnel leakage were upward with values that ranged from 1.6 to 5.4 times that measured at well U-1629. Because the groundwater in the bedrock in the vicinity of well U-1629 is not influenced by leakage from the RWB Tunnel, the head difference at this well may represent a normal hydraulic gradient between the bedrock and the unconsolidated deposits in this part of the valley. Four bedrock wells in the study area are flowing artesian wells (U-1625, U-1630, U-1631, and U-3772), with water levels above land surface (figs. 8 and 9). These conditions and the larger-thannormal upward flow of water measured at other bedrock wells indicate a significant flow-gradient potential from the bedrock to the unconsolidated deposits in parts of the study area. The 


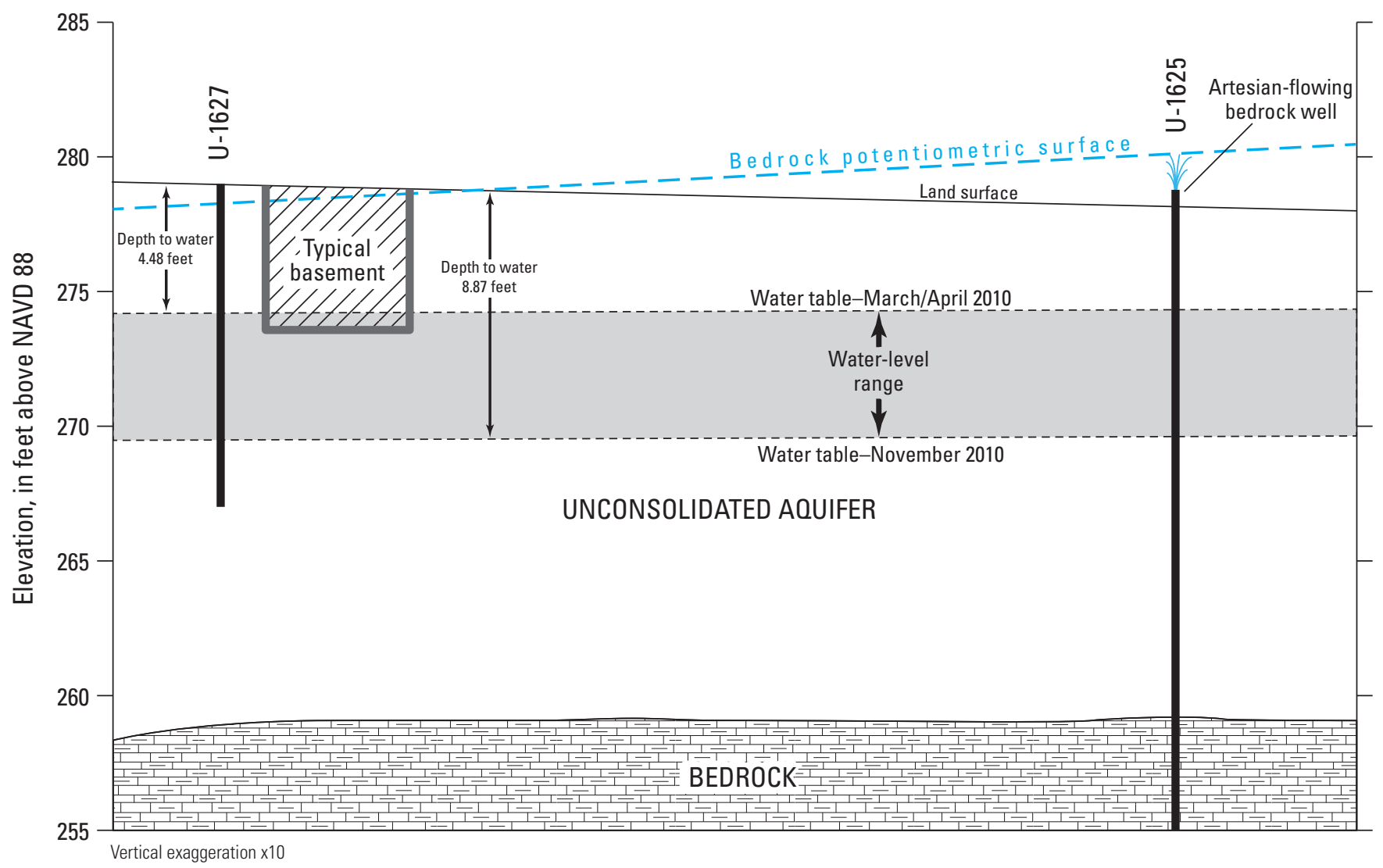

Figure 7. Hydrogeologic section $B$ to $B^{\prime}$ showing the difference in water levels between the unconsolidated and bedrock aquifers, Town of Wawarsing, Ulster County, New York. (Location is shown in figure 2.) 


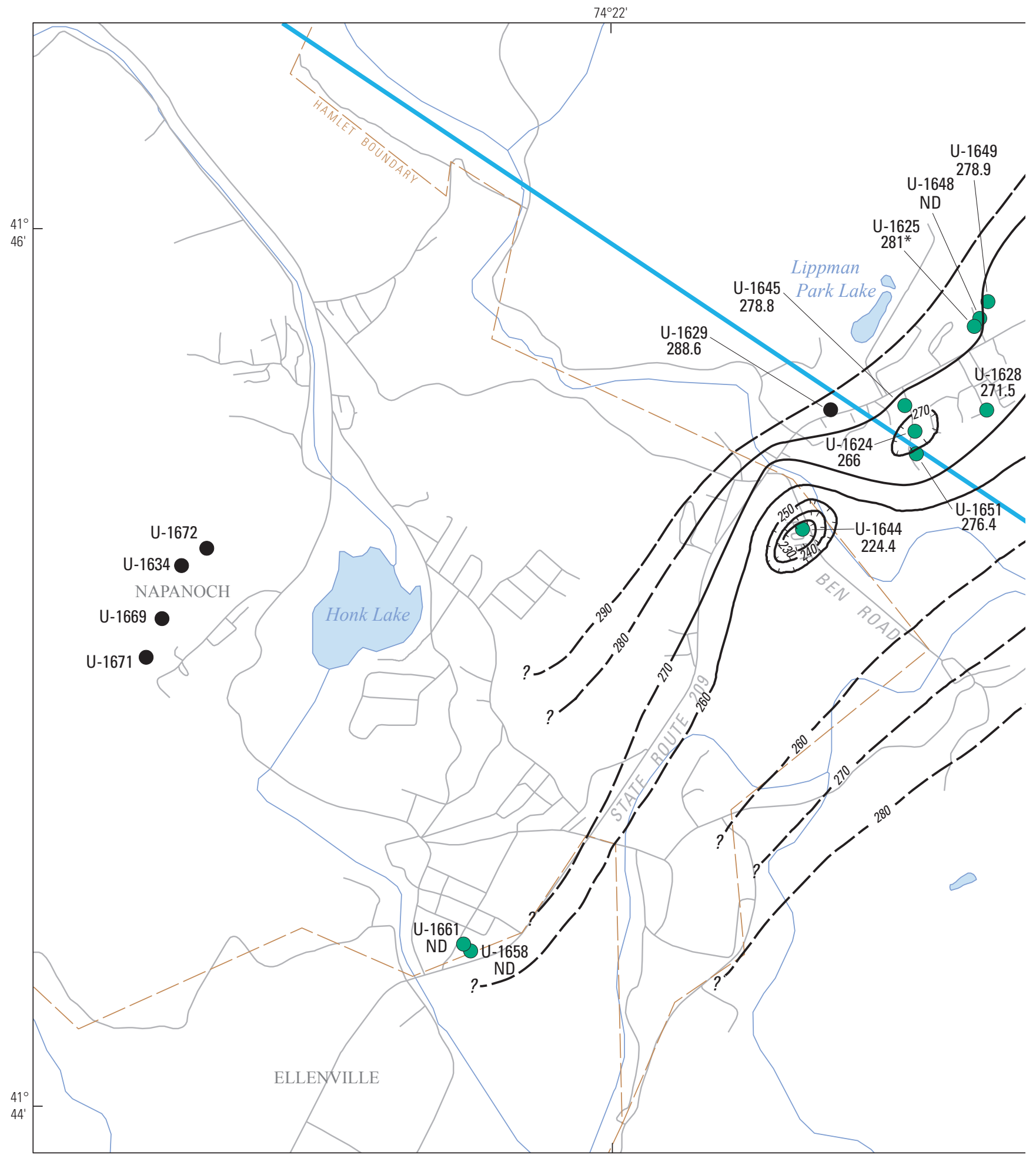

Base from U.S. Geological Survey Digital Data 1:100,000 series Lambert Conformal Conic Projection North American Datum of 1983

Figure 8. Elevation of the potentiometric surface in the bedrock aquifer within the study area, Town of Wawarsing, Ulster County, New York, March and April 2010. 


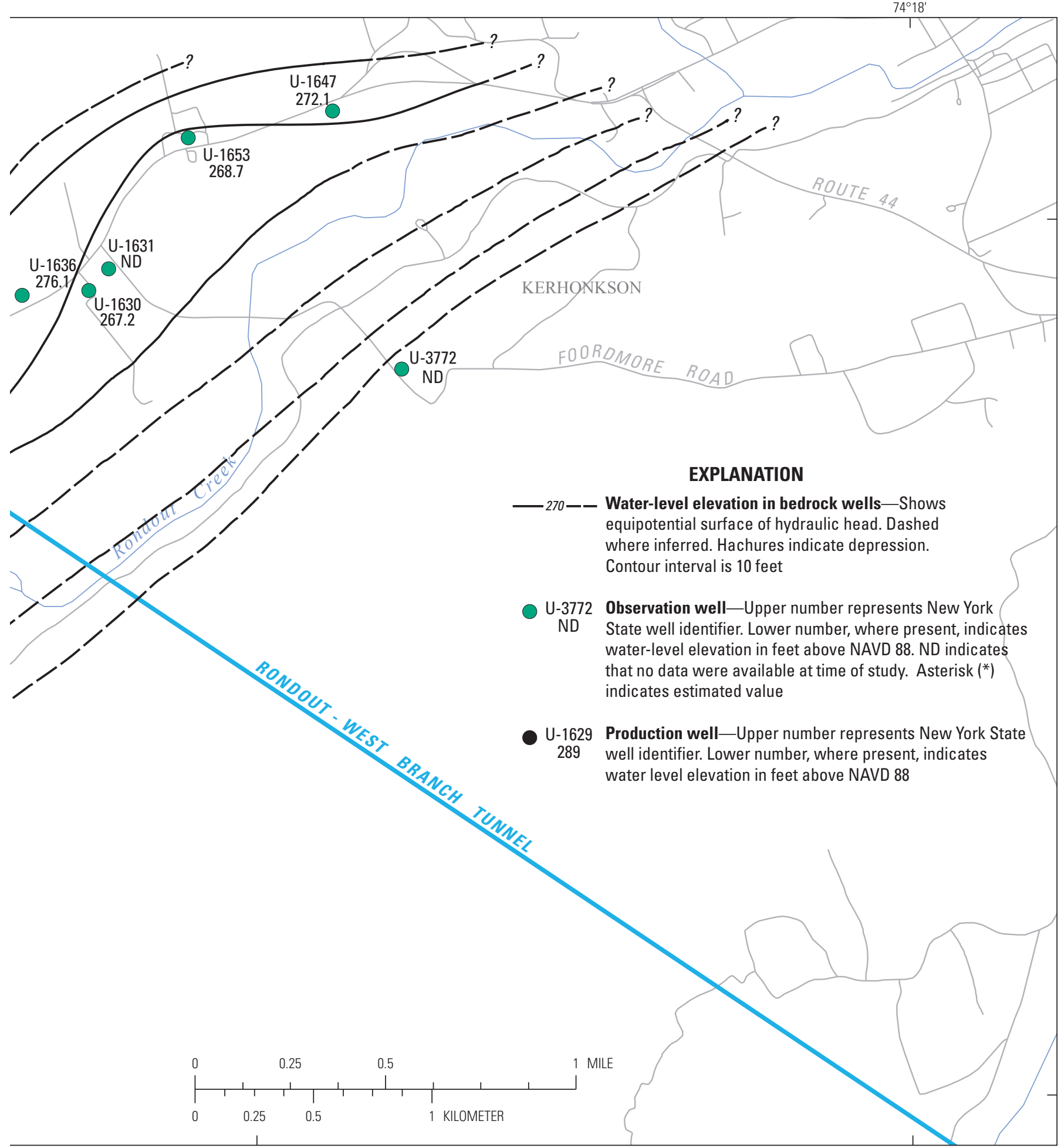

Figure 8. Elevation of the potentiometric surface in the bedrock aquifer within the study area, Town of Wawarsing, Ulster County, New York, March and April 2010.-Continued 


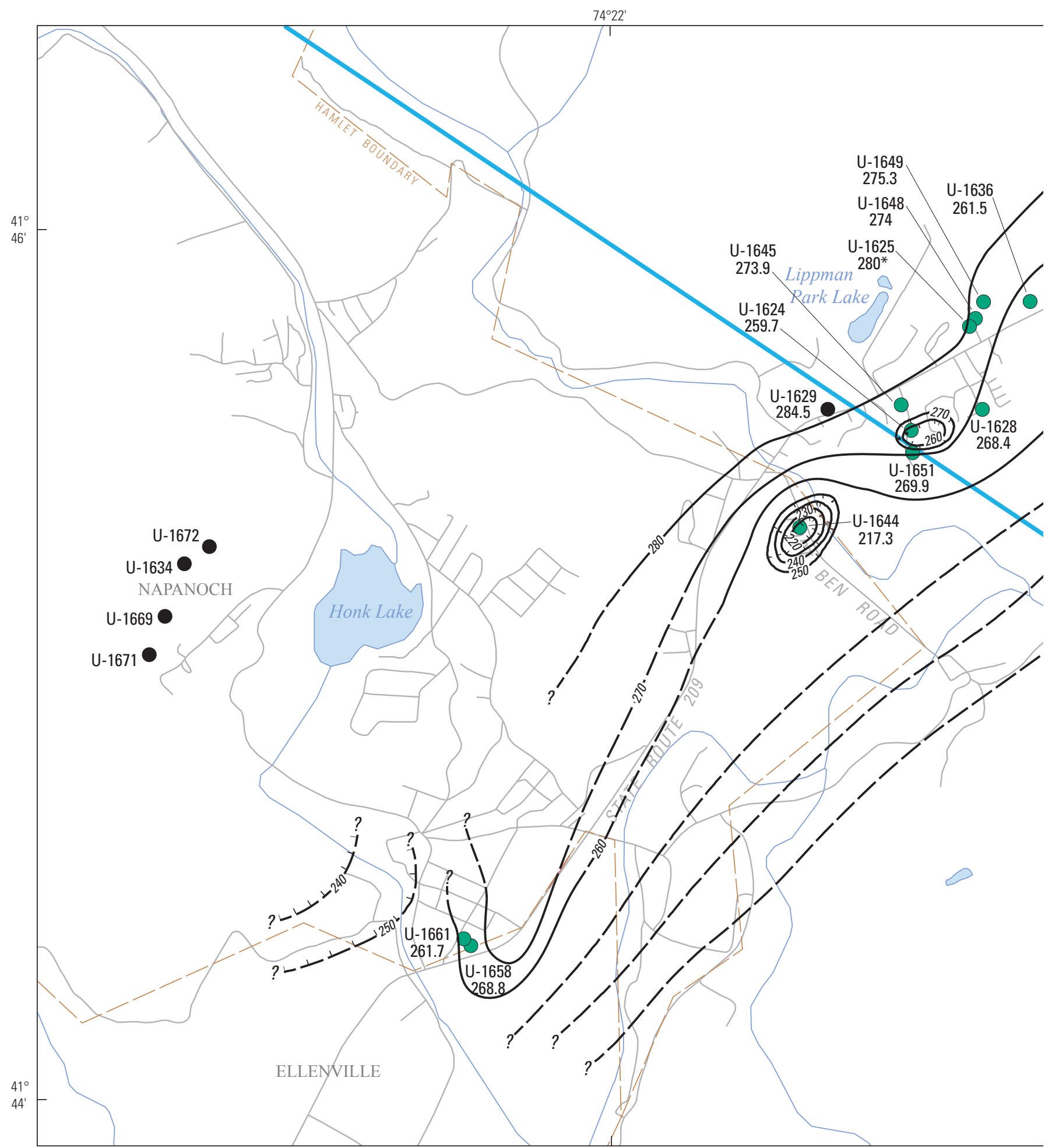

Base from U.S. Geological Survey Digital Data 1:100,000 series Lambert Conformal Conic Projection North American Datum of 1983

Figure 9. Elevation of the potentiometric surface in the bedrock aquifer within the study area, Town of Wawarsing, Ulster County, New York, November 2010. 


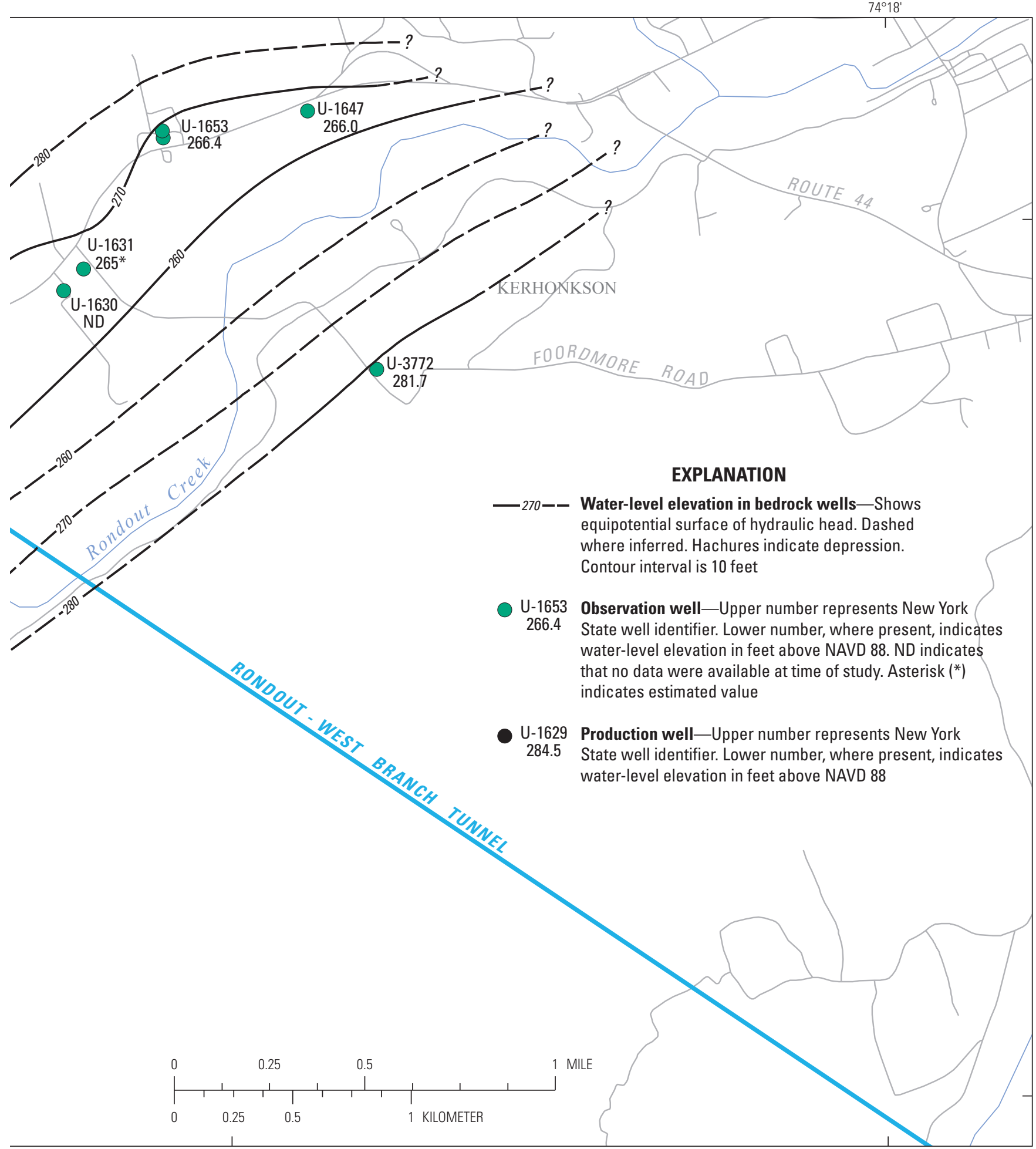

Figure 9. Elevation of the potentiometric surface in the bedrock aquifer within the study area, Town of Wawarsing, Ulster County, New York, November 2010.-Continued 
cross section shown in figure 7 illustrates the large difference in water levels between the unconsolidated and bedrock aquifers along Route 209 in Wawarsing, N.Y. The extent of this upward flow gradient in the eastern half of the study area is unknown because no bedrock observation wells were drilled for this study, and no private-supply bedrock wells were available in that part of the study area.

\section{Water Table in the Unconsolidated Aquifer}

Analyses of hydrographs indicate that the water-table elevation in the unconsolidated aquifer fluctuates in response to seasonal variations in precipitation, evapotranspiration, pumpage, and, in some wells, leakage from the tunnel through the underlying bedrock. The elevation of the water table in March/April ranged from $285 \mathrm{ft}$ (12.4 ft BLS) at well U-1664 at the western edge of the valley to $243.2 \mathrm{ft}$ (25.8 $\mathrm{ft}$ BLS) at well U-4862 near the central part of the valley, where groundwater discharges to the Rondout Creek (fig. 10). A similar (but lower) water-table configuration was measured in November 2010 (fig. 11). Groundwater in the unconsolidated aquifer generally flows from the surrounding hills east and west of the valley and from the southwest part of the valley toward the central and ultimately northeastern part of the valley (figs. 10 and 11).

Water levels were higher than the regional trend at wells U-1626, U-1638, and U-1656 in March/April 2010 (figs. 2 and 10). A similar high groundwater-level condition was observed in November 2010 (fig. 11). It is not clear whether this condition is related to the underlying bedrock water-level anomaly or to underlying lacustrine silt and clay (figs. 10 and 11).

An area of anomalously high groundwater levels with perched-like conditions (elevated groundwater separated from the regional water table) was observed at well U-1642, a shallow USGS observation well (figs. 6 and 11). Measured water-level elevations at U-1642 were consistently about $29 \mathrm{ft}$ higher than those in the deeper nearby wells U-1638 and U-1656 (figs. 2 and 11). Water-level elevations in well U-1642 do not correlate with those in the underlying regional groundwater-flow system and do not respond to changes in RWB tunnel pressure. The hydrograph from well U-1642 shows a limited and delayed response of water levels to variations in precipitation (fig. 6). Analysis of the dates of seasonal low and high water levels in well U-1642 indicates a 1-month lag compared to those in other unconsolidated-aquifer wells in the area and regionally (fig. 6). Vertical gradients in the unconsolidated aquifer in November 2010 at doublets U-1652 and U-1646, U-1641 and U-1637, and U-1659 and U-1640 were all upward, with head differences of 1.4, 2.6, and $3.3 \mathrm{ft}$, respectively (figs. 2, 10, and 11). In contrast, the vertical gradient in the unconsolidated aquifer within the area of anomalously high water levels (perched-like conditions) at doublet U-1642 and U-1656 was downward, with a head difference of $28.6 \mathrm{ft}$ (figs. 2, 10, and 11). This is the largest vertical head difference in any unconsolidated-aquifer well doublet within the study area. The large head differences, downward flow direction, lack of daily variations in water levels, lack of response to changes in RWB Tunnel pressure, and lag in seasonal low and high water levels compared to the regional aquifer response indicate that the anomalously high water levels (perched-like conditions) in this area probably are caused by the large amount of clay underlying this hilly deltaic deposit. Fine-grained sediments in this deposit appear to be responsible for springs that discharge from the upper slopes of this feature during seasonal (spring) periods of high precipitation. The upward flow gradients in the unconsolidated aquifer were greatest in the central parts of the valley where shallow groundwater discharges to the Rondout Creek and the aquifer is thickest (figs. 10 and 11).

\section{Hydrologic Effects of Temporary Shutdowns}

Since October 2008, the NYCDEP has shut down the RWB Tunnel four times: October 25-November 26, 2008; November 5-19, 2009; December 4-16, 2009; and January 13-26, 2010. During each shutdown, the tunnel pressure was slowly reduced from about $600 \mathrm{ft}$ to about $75 \mathrm{ft}$ elevation over a period of time that ranged from 34 to 56 hours, as measured in a nearby tunnel shaft. The repressurization process was accomplished in the same manner, by increasing the pressure in the RWB Tunnel from about $75 \mathrm{ft}$ to about $600 \mathrm{ft}$ elevation, over a period of time that ranged from 43 to 54 hours. Six of the eight cycles of depressurization and subsequent repressurization of the tunnel took place during a precipitation event (rainfall). Because the two events coincided, it was difficult to separate natural (precipitation) from artificial (RWB Tunnel leakage) recharge or discharge influences on water levels in the bedrock and unconsolidated aquifers.

\section{Tunnel-Leakage Influences on the Bedrock Aquifers}

Leakage from the RWB Tunnel increased water levels in wells in the bedrock aquifers for a distance of more than $7,000 \mathrm{ft}$ from the tunnel. Three bedrock wells (U-1625, U-1653, and U-1628) were selected to illustrate the tunnelinfluence response of the bedrock aquifers to RWB Tunnel shutdowns in 2009 and 2010 (figs. 2 and 12).

Bedrock well U-1625 is located about $1,820 \mathrm{ft}$ from the RWB Tunnel and is a flowing artesian private-supply well (figs. 2 and 12). Drawdowns in this well were minimal compared to those measured in other bedrock wells with similar pumps as a result of the high transmissivity of the local bedrock aquifer (fig. 12). The specific capacity and transmissivity at well U-1625 were estimated to be 4.62 gallons per minute per foot $((\mathrm{gal} / \mathrm{min}) / \mathrm{ft})$ and 1,325 feet squared per day $\left(\mathrm{ft}^{2} / \mathrm{d}\right)$, respectively. Specific 
capacity and transmissivity of the bedrock at well U-1625 were estimated using the hourly recorded water-level-elevation data from the digital data logger during a period that the RWB Tunnel was in operation under "normal," or typical (stable) tunnel pressures between shutdowns. The largest drawdown in the dataset was selected as the maximum drawdown for the test. The duration of the aquifer test was assumed to be the 1-hour period between measurements. Because the rate of withdrawal from the well could not be measured, it was estimated to be the pump's maximum rating of $12 \mathrm{gal} /$ min. The aquifer-test data were processed using a computer program (Bradbury and Rothschild, 1985) to calculate the transmissivity of the bedrock. Because of the uncertainties in pumping rates, pumping duration, and maximum drawdown, the calculated specific capacity and transmissivity of the well are considered to be estimates.

Analysis of the hydrographs recorded during the tunnel shutdowns indicates the bedrock aquifer in this area responds within about 0.5 hour of tunnel depressurization or repressurization (fig. 12). During the shutdowns, water levels decreased between 8 and $12 \mathrm{ft}$. The rapid response times to changes in tunnel pressure, the large changes in water level, and the long distance from the tunnel indicate that the fractures in this formation may be well connected with extremely high transmissivity. An interconnected fracture system affected by dissolution with large storage and transmissivity characteristics may exist locally in this aquifer.

Bedrock well U-1653 is located about 5,680 ft from the RWB Tunnel and was formerly an industrial-supply well (figs. 2 and 12). Analysis of the hydrograph from this well indicates that water levels decrease an average of 10 to 11 $\mathrm{ft}$ during tunnel shutdowns (fig. 12). In general, the bedrock aquifer in this area responds to changes in RWB Tunnel pressure within 6 to 8 hours. Like the water-level record from well U-1625, the record from well U-1653 indicates the presence of a well-connected and highly transmissive fracture network

A third bedrock well, U-1628, located $945 \mathrm{ft}$ from the RWB Tunnel is a private-supply well (figs. 2 and 12). The hydrograph from well U-1628 shows pumping drawdowns of 4 to $6 \mathrm{ft}$ (fig. 12), which indicate a moderately transmissive fracture network. Changes in the RWB Tunnel pressure caused water levels in this well to decrease 5 to $6 \mathrm{ft}$ during the shutdowns, with a tunnel-influence delay time of about 48 hours (fig. 12). This delay time indicates that the fracture network in this bedrock unit is less transmissive than those in wells U-1625 and U-1653.

Monitoring groundwater elevations in bedrock wells U-1624, U-1625, U-1628, U-1629, U-1630, U-1631, U-1645, U-1647, U-1649, and U-1653 at hourly intervals provided data on the magnitude and time delay of the tunnel-leakage influence on water levels in the bedrock underlying the study area (figs. 12, 13, and 14). Analysis of water levels in the bedrock wells during the four tunnel shutdowns indicates significant decreases in water levels followed by increases during repressurization (fig. 12). Most of these wells were instrumented during the second, third, and fourth shutdowns. The maximum water-level changes in the bedrock aquifers in the study area during tunnel shutdowns were contoured to determine patterns within the study area (fig. 13). Waterlevel changes during the shutdowns ranged from $12 \mathrm{ft}$ at well U-1625 to $1.5 \mathrm{ft}$ at well U-1645, with well U-1629 indicating no measurable influence from tunnel leakage (fig. 13).

Water-level-difference contours in figure 13 indicate that the areas of major changes in bedrock water levels due to tunnel influence were on either side of an area of lowest changes in water levels, at wells U-1645, U-1624, and U-1628. This area of lowest water-level response to tunnel influence may coincide with the Esopus Shale (figs. 3A, 3B, and 13). The larger water-level responses to tunnel influence on either side of these wells appear to correlate with the presence of limestone units in contact with the shale (figs. 3A, 3B, and 13). Water levels in well U-1629 indicated no tunnel-influence response although this well was among those closest to the RWB Tunnel. Wells U-1653 and U-1647 were the farthest measured wells from the RWB Tunnel (about 5,680 and 7,100 ft, respectively), but they indicated waterlevel responses to tunnel influence (tunnel leakage) (fig. 13). Because no bedrock observation wells are located on the east side of the valley, it was not possible to determine the waterlevel responses to tunnel influence in half of the study area. One new private-supply bedrock well in the northeastern part of the study area, U-3772, was added to the monitoring network in November 2010, after the fourth shutdown (January 2010). Because no tunnel shutdowns have occurred since January 2010, it is unclear whether the bedrock in this part of the study area is influenced by leakage from the RWB Tunnel. Additional monitoring during shutdowns would help to determine whether tunnel leakage affects water levels in this area.

Analysis of the hydrographs from bedrock wells during tunnel shutdowns indicated tunnel-leakage influence delay times that ranged from about 0.5 to 60 hours (fig. 14). Tunnelinfluence delay times were shortest at wells U-1625 (about 0.5 hour), U-1649 (14 hours), and U-1653 (7 hours) (fig. 14). Tunnel-influence delay times at most bedrock wells influenced by tunnel leakage ranged from 21 to 33 hours (fig. 14). The longest tunnel-influence delay times were not in the wells farthest from the tunnel, which indicates the presence of a complex, transmissive bedrock fracture network. Tunnelinfluence delay times were longest $(48,48$, and 60 hours, respectively) in bedrock wells U-1628, U-1624, and U-1631 (fig. 14). Wells U-1628 and U-1624 were among the four wells closest to the tunnel.

The hydrologic response of the bedrock aquifer to tunnel shutdowns is consistent with its preliminary characterization as an anisotropic aquifer with greater transmissivity along bedding strike than across bedding strike. The response is also consistent with the presence of a discrete high-transmissivity network, likely along fractured limestone beds that have been affected by dissolution (Freeze and Cherry, 1979). 


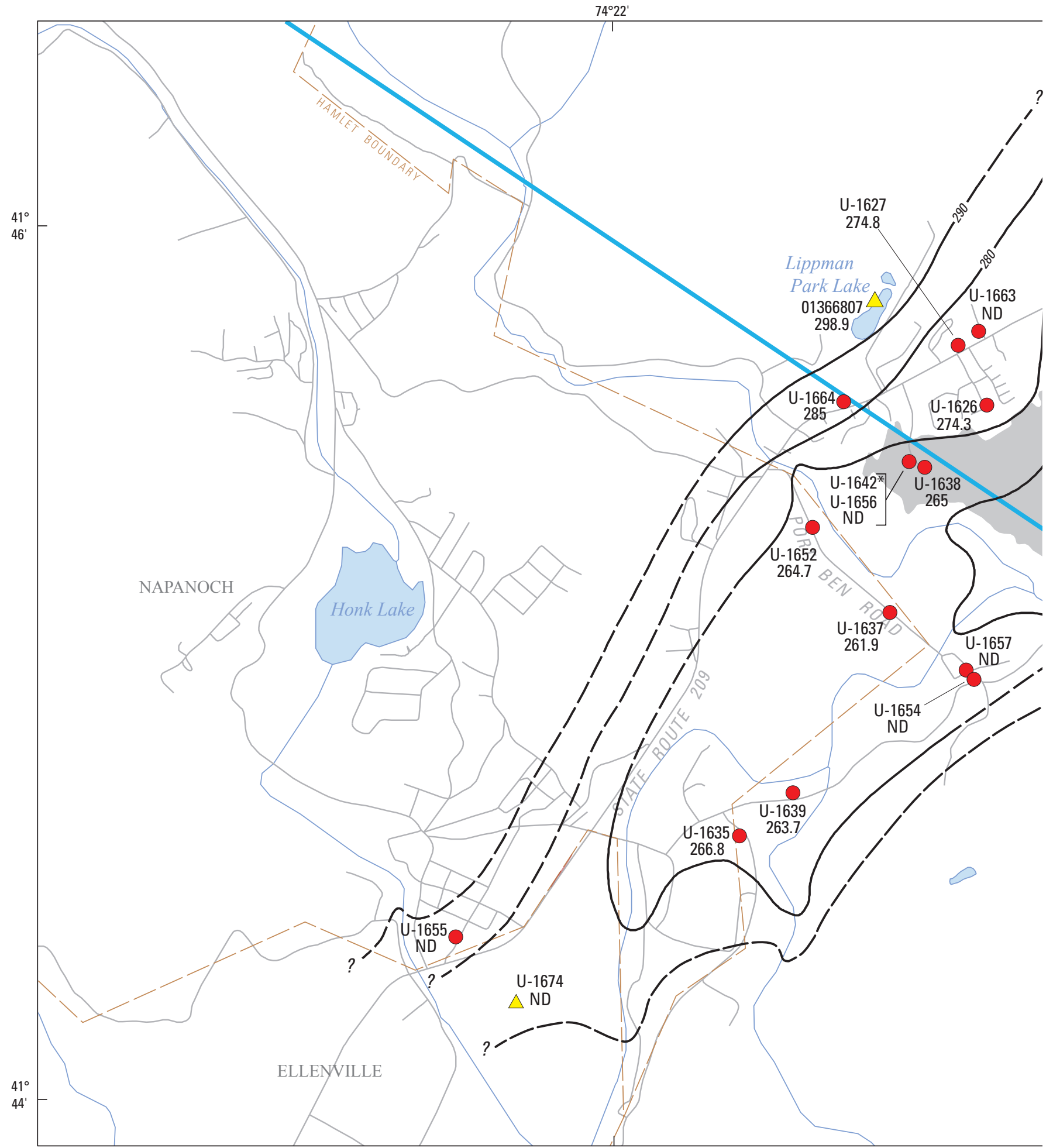

Base from U.S. Geological Survey Digital Data 1:100,000 series Lambert Conformal Conic Projection North American Datum of 1983

Figure 10. Elevation of the water table in the unconsolidated aquifer within the study area, Town of Wawarsing, Ulster County, New York, March and April 2010. 


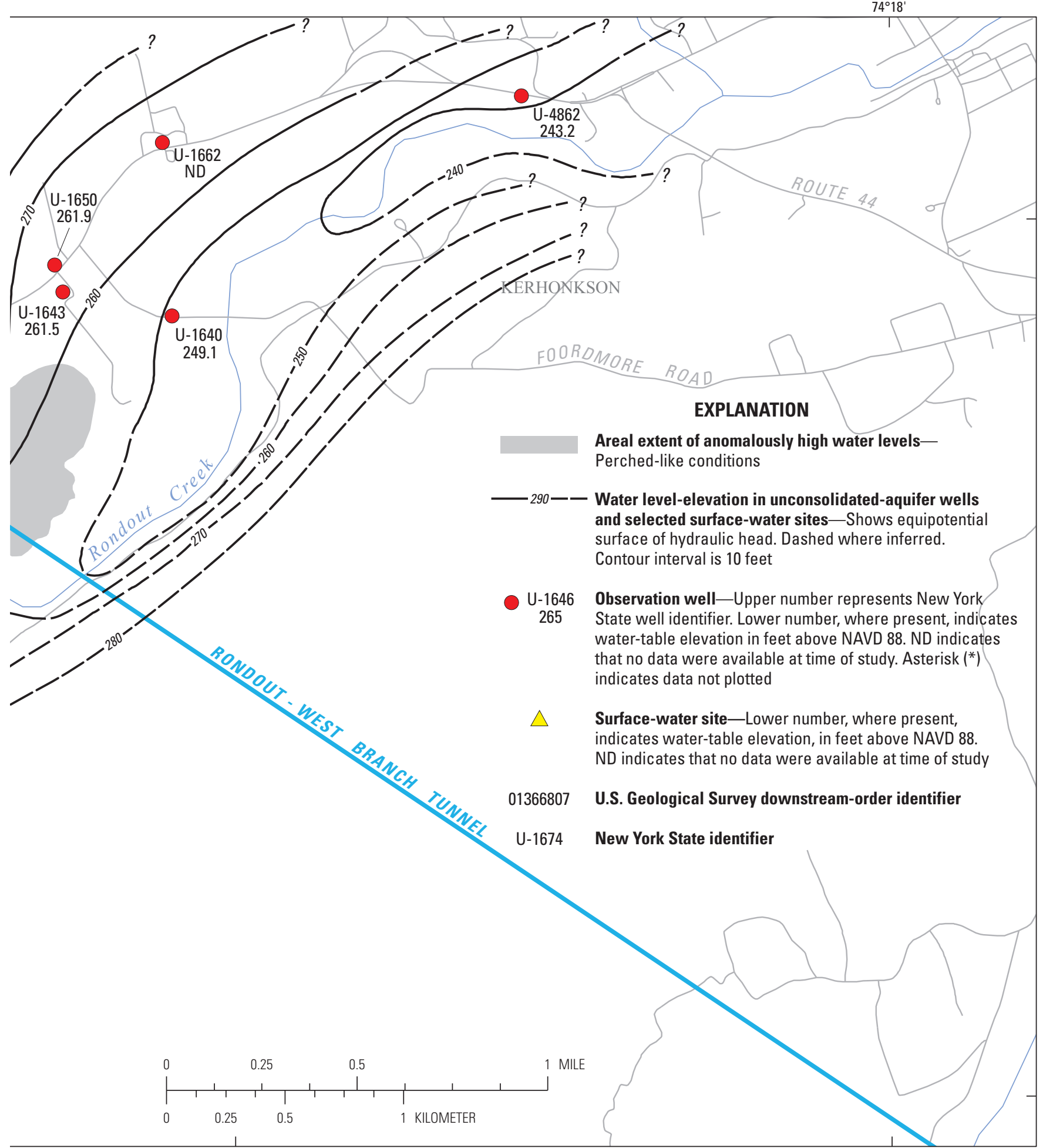

Figure 10. Elevation of the water table in the unconsolidated aquifer within the study area, Town of Wawarsing, Ulster County, New York, March and April 2010.-Continued 


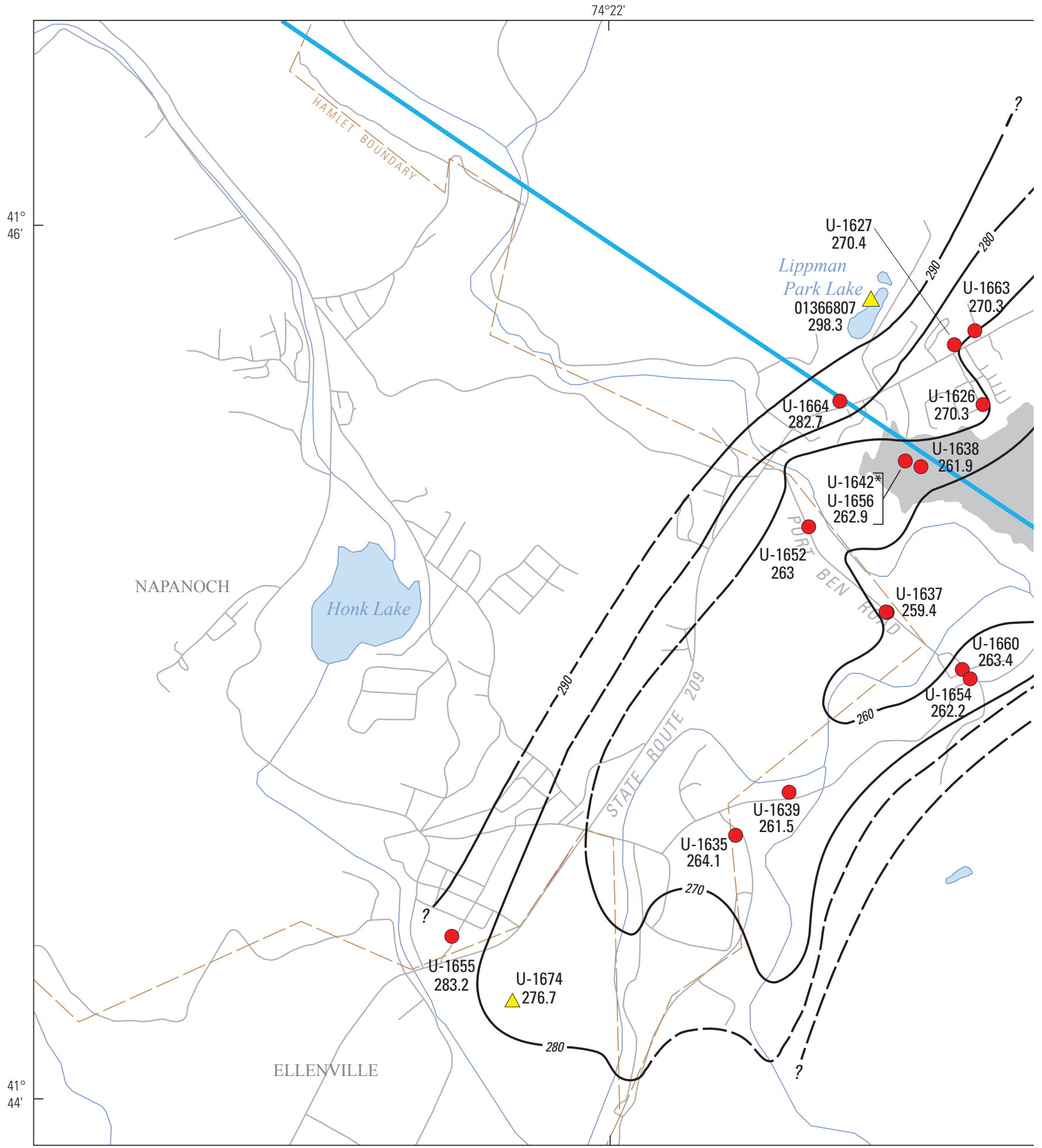

Base from U.S. Geological Survey Digital Data 1:100,000 series Lambert Conformal Conic Projection North American Datum of 1983

Figure 11. Elevation of the water table in the unconsolidated aquifer within the study area, Town of Wawarsing, Ulster County, New York, November 2010. 


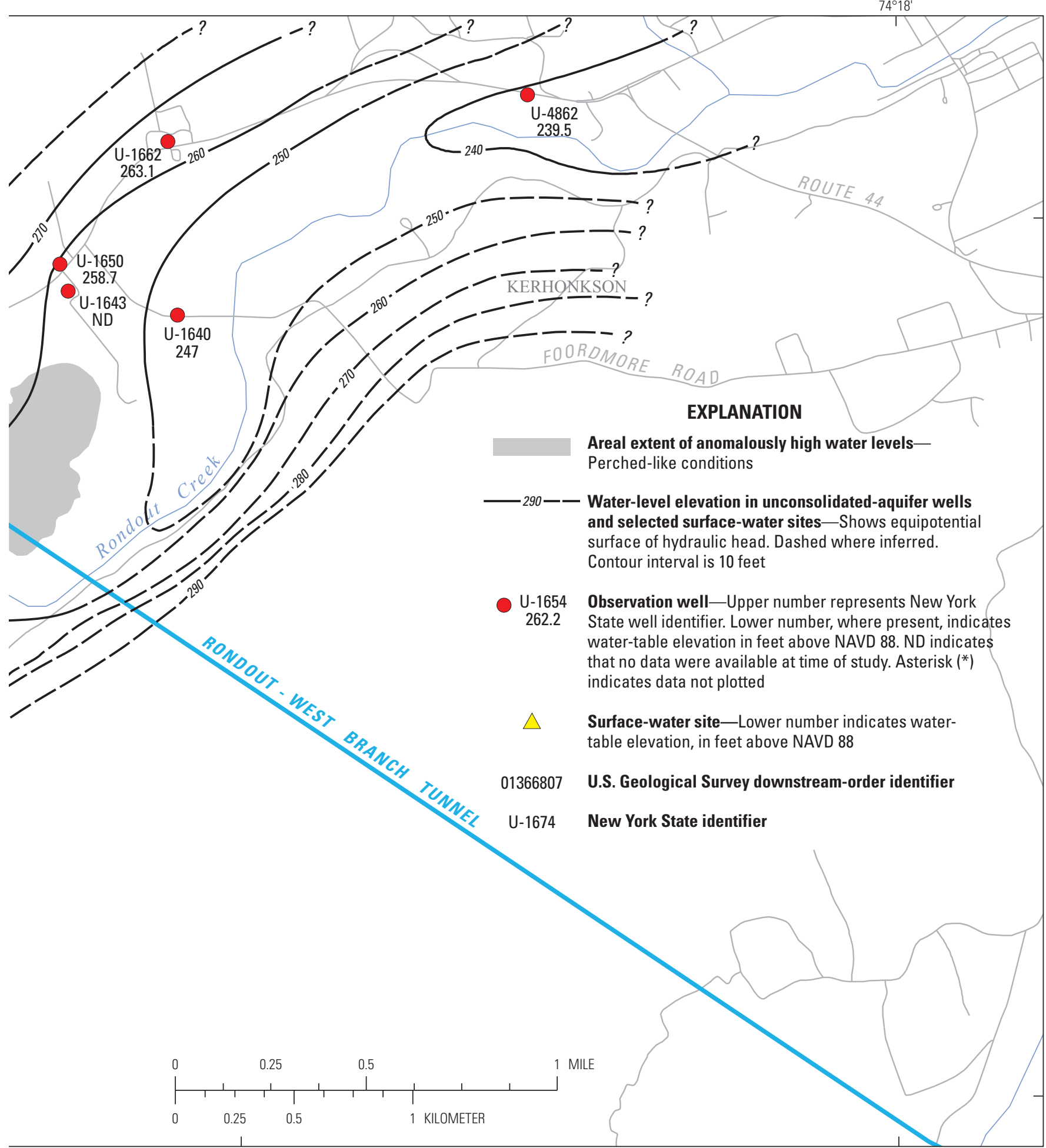

Figure 11. Elevation of the water table in the unconsolidated aquifer within the study area, Town of Wawarsing, Ulster County, New York, November 2010.-Continued 

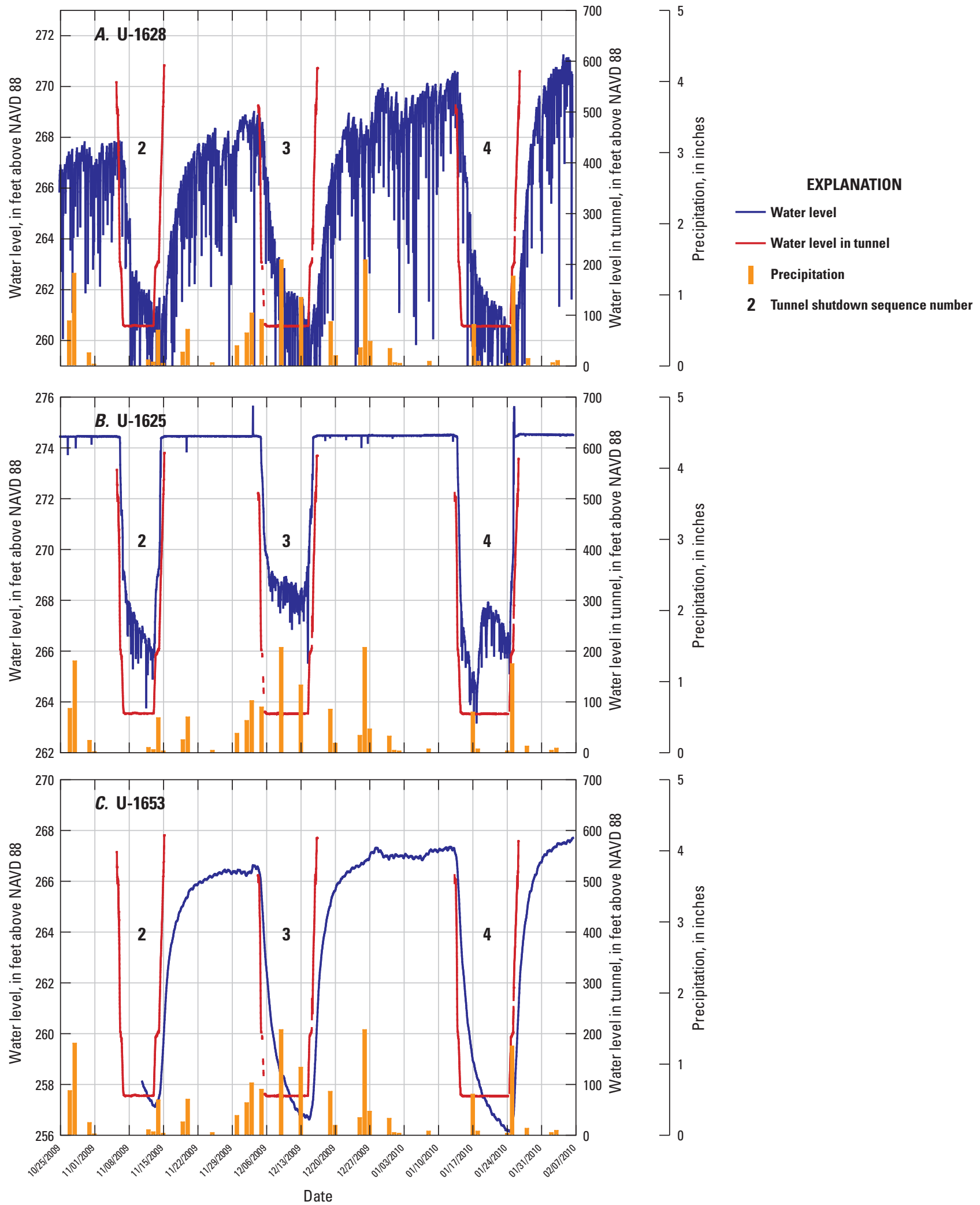

Figure 12. Graphs showing the potentiometric-surface elevation in bedrock wells, the water level in the Rondout-West Branch Tunnel, and precipitation within the study area, Town of Wawarsing, Ulster County, New York: A, well U-1628, October 25, 2009February 06, 2010; B, well U-1625, October 25, 2009-February 06, 2010; and C, well U-1653, November 10, 2009-February 06, 2010. (Precipitation data from National Oceanic and Atmospheric Administration station in Central Park, N.Y.; tunnel water-level data from New York City Department of Environmental Protection; for locations, see figure 1.) 


\section{Tunnel Leakage to the Unconsolidated Aquifers}

Observation and private-supply wells in the unconsolidated aquifers were monitored to determine the extent of the influence of RWB Tunnel leakage in the unconsolidated aquifer overlying the bedrock. The presence of an upward flow gradient from the underlying bedrock aquifer to the unconsolidated aquifer greater than that due to natural conditions indicates that transmissive bedrock fractures that crop out on the bedrock surface (beneath the unconsolidated aquifer) potentially can transmit water from the RWB Tunnel to the unconsolidated aquifer above.

If the delay between tunnel leakage and the response of the bedrock aquifer averages more than 20 hours, the tunnelinfluence delay time for the unconsolidated aquifer likely is even longer. This additional delay is due to the dispersion of inflow (from the underlying bedrock), which is dependent on the transmissivity and storativity of the unconsolidated aquifer, making it difficult to quantify tunnel leakage that has been discharged from the underlying bedrock aquifer to the unconsolidated aquifer. The occurrence of precipitation during or soon after repressurization of the RWB Tunnel is an obstacle to quantifying potential leakage from the tunnel to the unconsolidated aquifer.

Water leaking from the RWB Tunnel has been documented to enter the adjacent bedrock in Roseton and Wawarsing, N.Y. (James Canale, New York City Department of Environmental Protection, written commun., 2011). Data from this study indicate that this leakage causes water levels in the bedrock aquifer in Wawarsing to increase as much as $12 \mathrm{ft}$. Measuring the extent of tunnel leakage to the unconsolidated aquifer is difficult as a result of (1) the large influence of recharged precipitation, (2) the dispersion of tunnel-leakage inflow from the bedrock aquifer into the unconsolidated aquifer (porous media), and (3) the limited number of screened unconsolidated wells available in which to measure water levels.

The large influence of precipitation on water levels in the unconsolidated aquifer can be seen in the hydrograph from well U-1627 (fig. 15). Rain events greater than about 1 in. cause measurable increases in the water levels in the unconsolidated aquifer. The hydrograph of well U-1627 indicates this increase as an upward spike (recharge) followed by a slow decline (discharge) (fig. 15).

To illustrate the influence of precipitation on groundwater levels in the unconsolidated aquifer, a multiday storm was analyzed during "normal," or typical (stable) tunnel pressures between shutdowns. The storm produced 2.05 in. of rainfall over a 3-day period from December 25 to 27, 2009 (fig. 15). Daily rainfall totals on December 25, 26, and 27 were 0.24 , 1.48 , and 0.33 in., respectively (National Oceanic and Atmospheric Administration, 2010). Water levels at well U-1627 in the unconsolidated aquifer began to rise from an elevation of $271.3 \mathrm{ft}$ ( $8.0 \mathrm{ft}$ BLS) on December 27 and reached a peak elevation of $272.7 \mathrm{ft}$ ( $6.6 \mathrm{ft} \mathrm{BLS}$ ) on December 28 (fig. 15). The water-table elevation rose $1.4 \mathrm{ft}$ as a result of recharge of precipitation from the storm. Water-table responses to precipitation indicate rapid changes in water levels in parts of the unconsolidated aquifer within the study area. When combined with localized constrained (shallow permeable layers underlain by clay) aquifer effects, seasonally large amounts of precipitation can cause large increases in groundwater levels.

To properly separate the effects of recharging precipitation from tunnel-leakage inflows (from the underlying bedrock aquifer) in the unconsolidated aquifer requires tunnel depressurizations and repressurizations to occur during dry periods. During the second tunnel shutdown (November 5-12, 2009), depressurization did occur during a dry period. The weather was also dry during the repressurization of the third shutdown (December 4-16, 2009). These events were used to determine the influences of tunnel leakage on the unconsolidated aquifer.

Unconsolidated-aquifer well U-1627 is located $1,460 \mathrm{ft}$ from the RWB Tunnel (fig. 2). The well is a limited-use private-supply well that was dug in the shallow part of the aquifer. The hydrograph of water levels in well U-1627 and the water levels in the RWB Tunnel during the last three of the four tunnel shutdowns investigated in this study are shown in figure 15.

The deflection of the hydrograph at the beginning of shutdowns 2 and 4 and the continued drop in water levels during the shutdowns indicate the influence of leakage from the tunnel on the unconsolidated aquifer in this area. During shutdown 3, precipitation occurred during the depressurization, in the middle, and toward the end of the shutdown (fig. 15). A spike of precipitation-induced recharge can be seen in the middle of shutdown 3 ; however, the weather was dry during the repressurization in shutdown 3 , and a distinct increase in water levels was detected (fig. 15). The hydrograph shapes are distinctively different during recessional discharge after precipitation than during tunnel depressurization (fig. 15). Similar effects were observed at unconsolidated-aquifer well U-1626, although the amplitude was much smaller because the well is shallower than well U-1627 and the depth to bedrock is greater (about 50 to $60 \mathrm{ft}$ BLS) (fig. 2).

To determine the effect of the inflows from the RWB Tunnel into the unconsolidated aquifer in areas with greater depths to bedrock, the USGS drilled a deep and a shallow unconsolidated-aquifer observation-well doublet (U-1637 and U-1641) in the center of the valley (fig. 2). An unpublished USGS seismic survey completed in 2008-09 indicated a depth to bedrock of about $310 \mathrm{ft}$ at these wells. Well U-1641 was drilled to a depth of $134 \mathrm{ft}$ BLS and U-1637 to a depth of $27 \mathrm{ft}$ BLS. A hydrograph of well U-1641 indicates a decrease in water levels of 2 to $2.5 \mathrm{ft}$ during each of the last three shutdowns with clearly defined troughs similar to those seen in bedrock hydrographs (figs. 12 and 15). Tunnel-influence delay time was only about 18 hours, indicating that the bedrock, which is about $170 \mathrm{ft}$ deeper than well U-1641, probably contains highly transmissive fractures or features that respond 


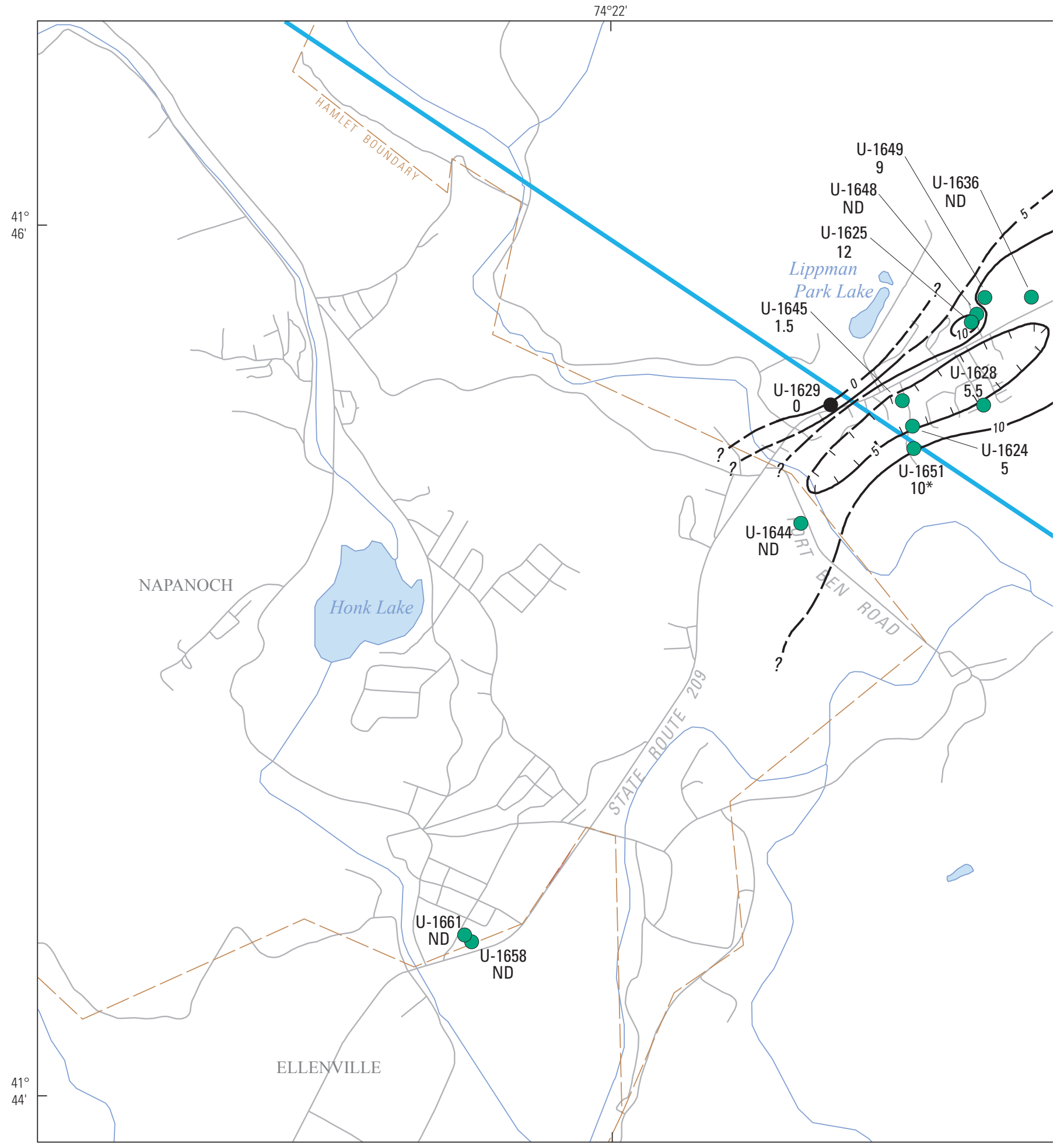

Base from U.S. Geological Survey Digital Data 1:100,000 series Lambert Conformal Conic Projection

North American Datum of 1983

Figure 13. Maximum water-level response to influence of tunnel leakage on the bedrock aquifer within the study area, Town of Wawarsing, Ulster County, New York, 2009-10. 


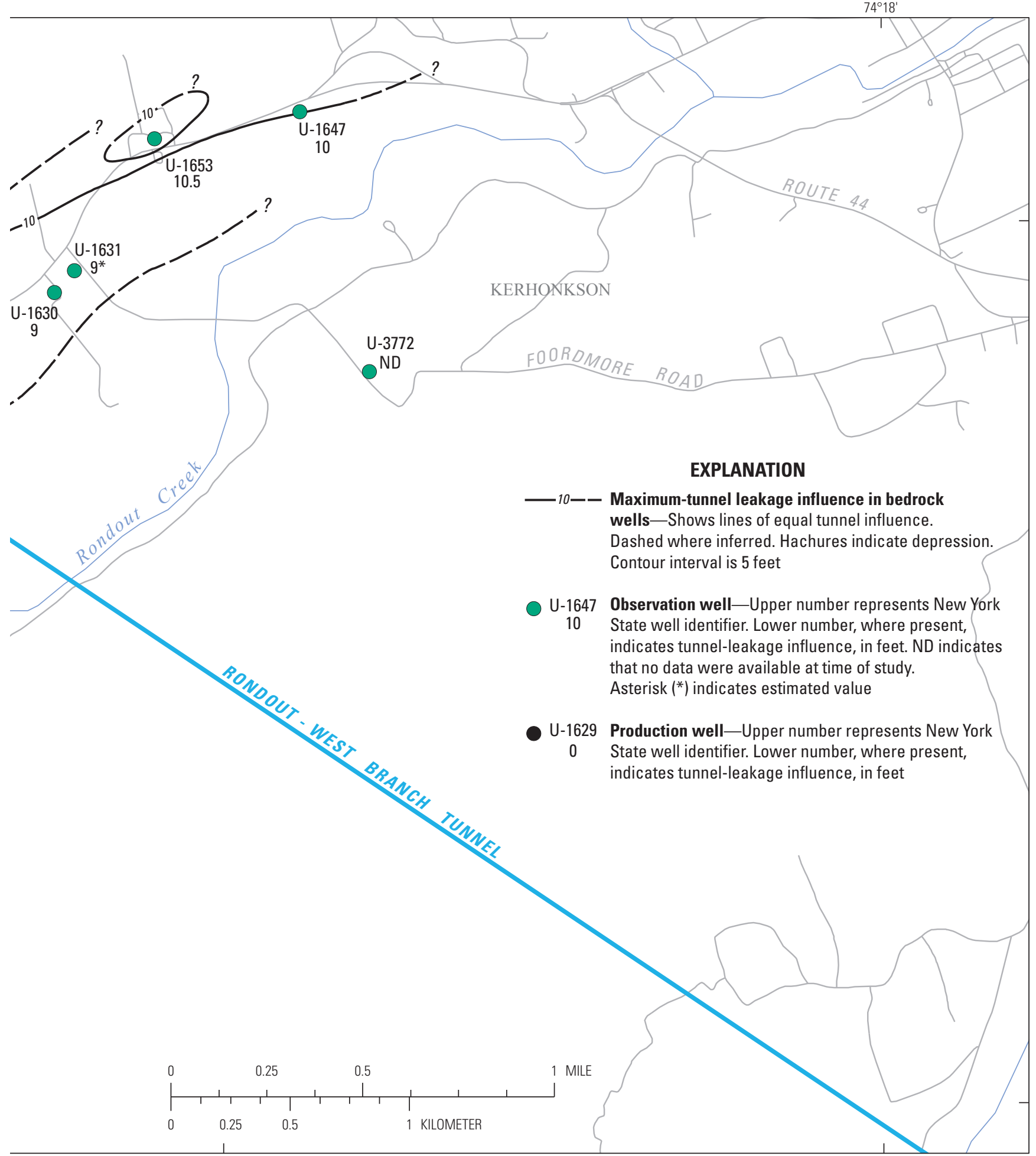

Figure 13. Maximum water-level response to influence of tunnel leakage on the bedrock aquifer within the study area, Town of Wawarsing, Ulster County, New York, 2009-10. - Continued 


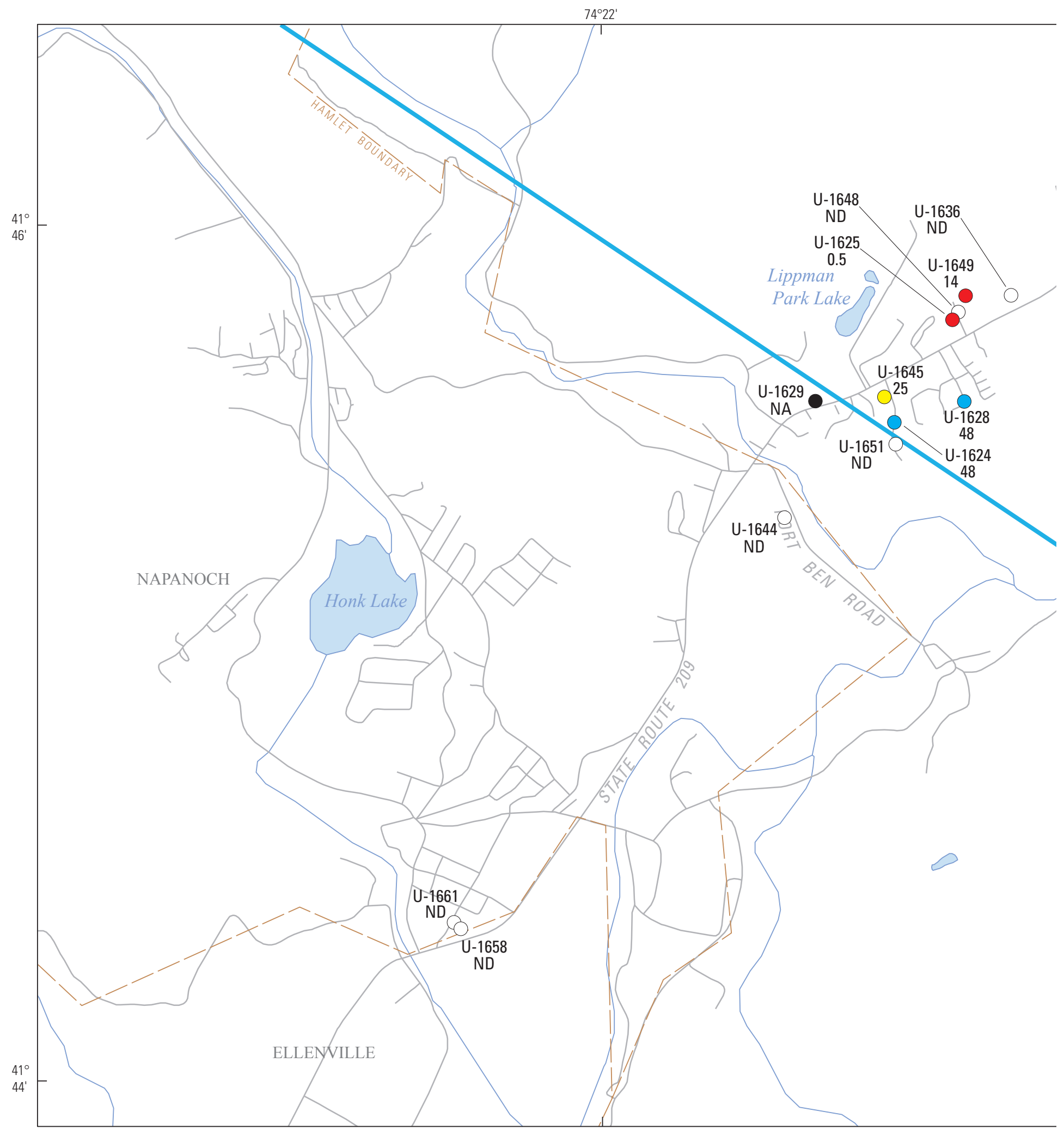

Base from U.S. Geological Survey Digital Data 1:100,000 series

Lambert Conformal Conic Projection

North American Datum of 1983

Figure 14. Tunnel-leakage influence delay time on water levels in bedrock wells within the study area, Town of Wawarsing, Ulster County, New York, 2009-2010. 


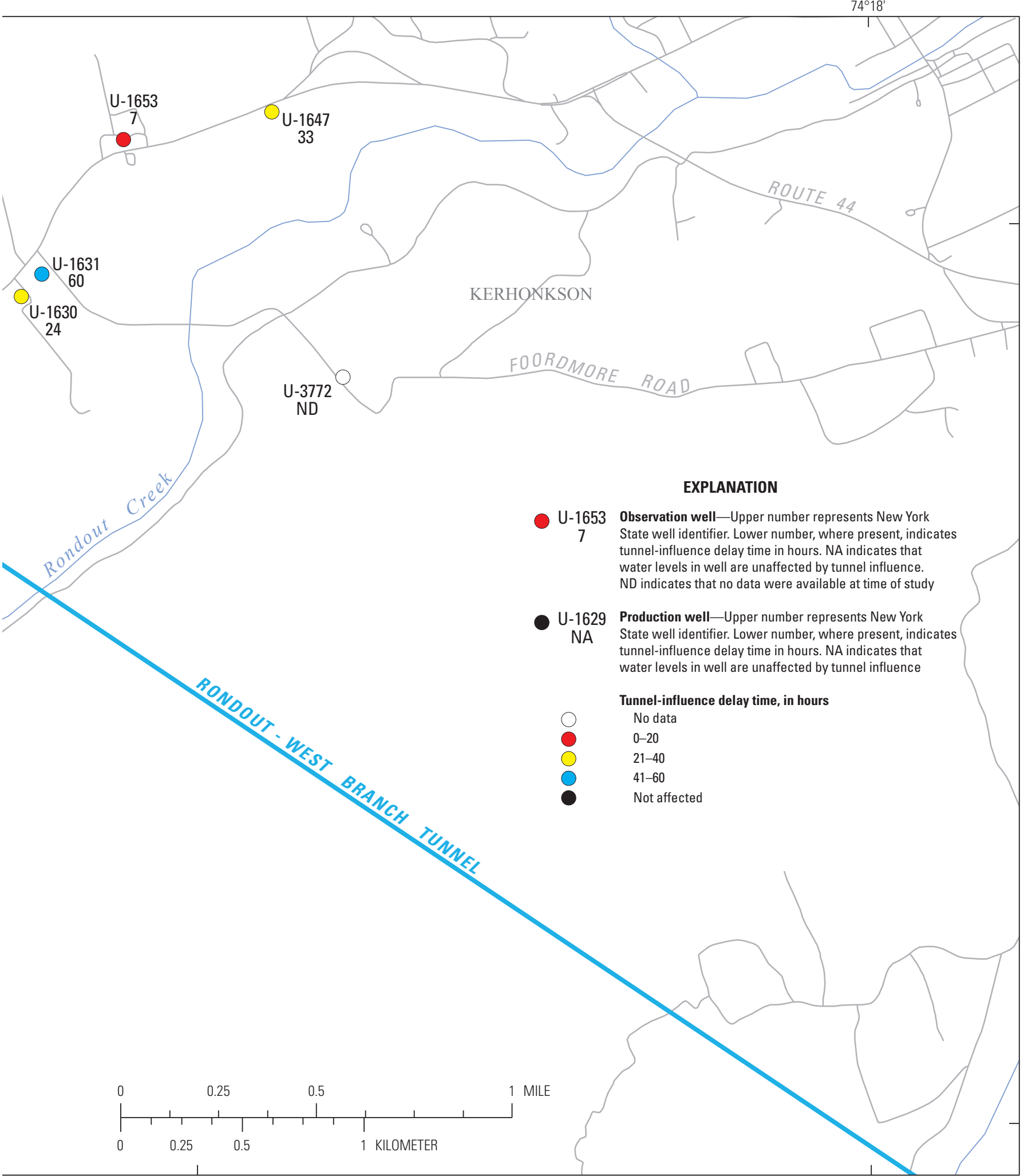

Figure 14. Tunnel-leakage influence delay time on water levels in bedrock wells within the study area, Town of Wawarsing, Ulster County, New York, 2009-2010.-Continued 

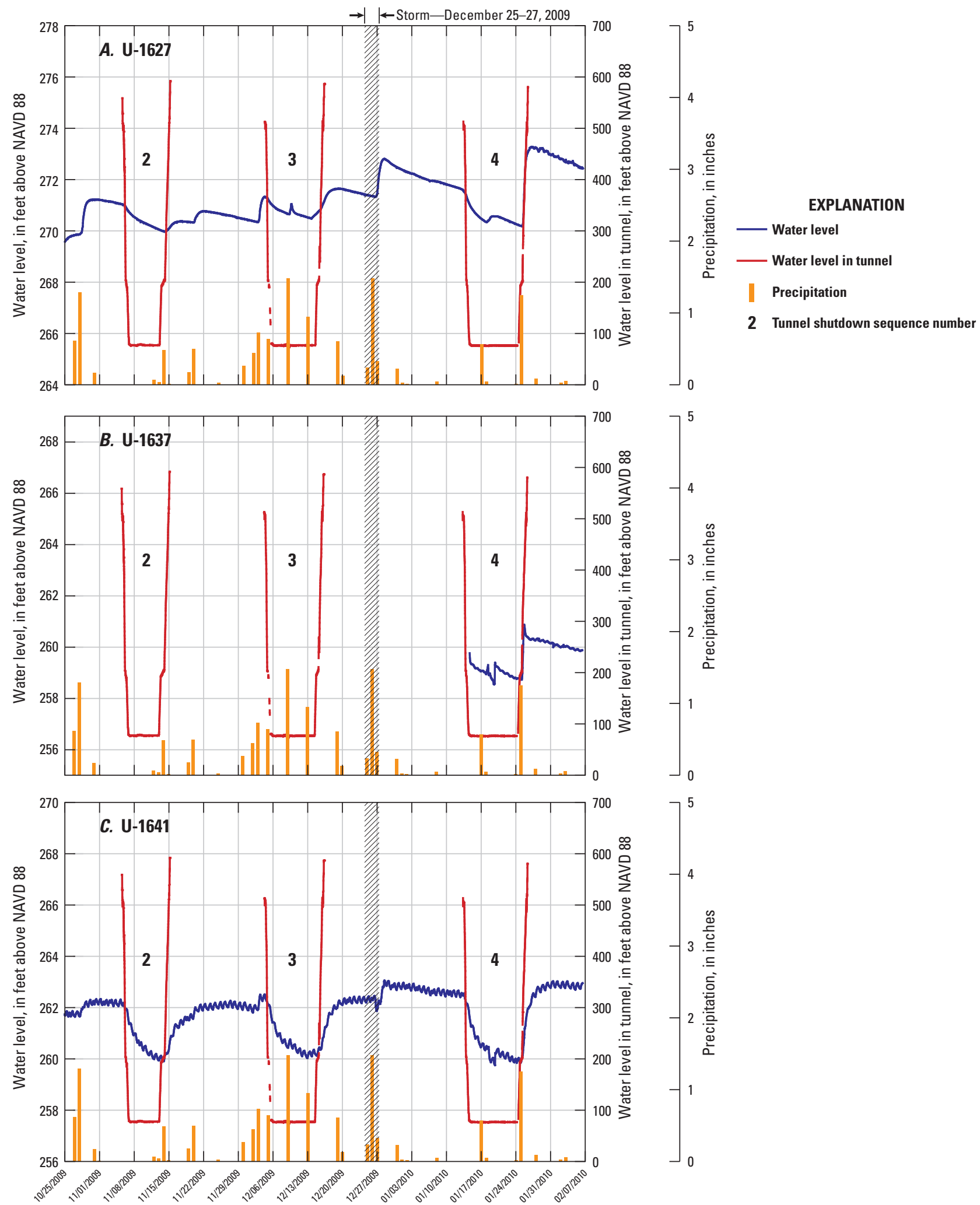

Date

Figure 15. Graphs showing the water-table elevation in unconsolidated-aquifer wells, tunnel water level, and precipitation data within the study area, Town of Wawarsing, Ulster County, New York: A, well U-1627, October 25, 2009-February 06, 2010; B, well U-1637, January 14, 2010-February 06, 2010; and C, well U-1641, October 25, 2009-February 06, 2010. (Precipitation data from National Oceanic and Atmospheric Administration station in Central Park, N.Y.; tunnel water-level data from New York City Department of Environmental Protection; for locations, see figure 1.) 
quickly to changes in tunnel pressure (fig. 15). A bedrock observation well at this location was not available to verify this hypothesis. Small daily increases and decreases in the water levels in wells U-1641 and U-1637 over several hours are caused by the nearby pumping of production wells at the Eastern/Ulster Correctional Facility (U-1670 and U-1673) (figs. 2 and 15).

In contrast to well U-1641, well U-1637, at the same location, was screened in a shallower part of the unconsolidated aquifer (figs. 2 and 15). The hydrograph of well U-1637 begins during the depressurization stage of the fourth and last tunnel shutdown on January 15, 2010 (fig. 15). The shallower part of the unconsolidated aquifer shows a smaller water-level response to tunnel influence than the deeper part (fig. 15). The fourth RWB Tunnel shutdown lowered the water table $0.8 \mathrm{ft}$. The shallower part of the aquifer responded later (longer delay time) and with a smaller water-level response to tunnel influence than the deeper portion, reflecting the dispersion in the unconsolidated aquifer (fig. 15).

A contour map of the maximum measured influence of leakage from the RWB Tunnel into the unconsolidated aquifer is shown in figure 16. The aquifer appears to dissipate (disperse) the transmitted leakage or pressure wave from the underlying bedrock to a larger area with small amplitudes in the unconsolidated aquifer. Influences of the RWB Tunnel shutdowns were detected in unconsolidated-aquifer wells U-1626, U-1627, U-1637, U-1638, U-1641, and U-1650 (fig. 16).

No measurable water-level response to RWB Tunnel shutdowns were detected in digital recorders at unconsolidated-aquifer wells U-1640, U-1642, U-1652, U-4862, and USGS lake-level gage 01366807 (fig. 2). These wells are screened at various depths and are located in separate areas of the study area. This absence of response indicates that the influences from tunnel leakage occur in isolated locations in the study area; however, the absence of wells in the eastern part of the area limits the ability to determine the influences from tunnel leakage in half of the study area. New observation-well drilling and monitoring during future tunnel shutdowns would provide valuable information about this part of the study area.

Analysis of digitally and manually obtained water levels in the unconsolidated-aquifer wells during the four tunnel shutdowns indicates measurable decreases in the water table during depressurizations, followed by increases during repressurizations (figs. 15 and 16). Precipitation has a large influence on water levels in the unconsolidated aquifer, and nearly every tunnel shutdown began and ended during a precipitation event (figs. 12 and 15). Tunnel shutdown 3 offered better conditions for assessing the influence of tunnel leakage on groundwater levels than did the other tunnel shutdowns. The maximum changes in water levels in the unconsolidated aquifer ranged from $0.1 \mathrm{ft}$ at well $\mathrm{U}-1650$ to $2.5 \mathrm{ft}$ at well U-1641 (fig. 16); however, it is estimated that inflows of tunnel leakage caused an increase of 0.1 to $0.5 \mathrm{ft}$ in water levels in the unconsolidated aquifer in the vicinity of wells U-1627 and U-1626 (fig. 16). The water-leveldifference contours in figure 16 correlate with recharge to the unconsolidated aquifer from the underlying bedrock resulting from tunnel leakage (fig. 13). The changes were greatest along Port Ben Road (wells U-1641 and U-1637), where USGS seismic surveys and drilling indicated greater depths to bedrock (figs. 15 and 16). The location of wells U-1637 and U-1641 is adjacent to the section of the RWB Tunnel that required the steel interliner due to poor bedrock quality and large groundwater inflows (more than $9,000 \mathrm{gal} / \mathrm{min}$ ) during construction (figs. 2 and $3 \mathrm{~A}$ ).

The tunnel-influence delay time in the unconsolidated aquifer ranged from about 18 hours at wells U-1627 and U-1641 to 54 hours at well U-1650 (fig. 17). Generally, the tunnel-influence delay time was shortest in the wells displaying the largest water-level responses to tunnel influence (largest amplitude) and longest in the wells showing the smallest water-level responses to tunnel influence (smallest amplitude). Water-level amplitudes may be underestimated at some of the unconsolidated-aquifer wells that were dug wells because these wells may be less effectively connected with the aquifer than screened wells. Shallow wells in areas of thick overburden may be a poor indicator of possible influences from tunnel leakage because of the dispersion effect. Several of the unconsolidated-aquifer observation wells that indicated larger water-level response to tunnel influence were screened deeper in the aquifer.

In general, the largest influence on water levels regionally was precipitation, but pumpage and (or) tunnel leakage had large influences in some wells locally. In the spring, when water levels are highest, the water table is in direct contact with some basements locally, causing basement flooding. During the summer and late fall, water levels decrease an average of $5 \mathrm{ft}$ and are below most basements, resulting in a lack of basement flooding. In the unconsolidated aquifer, elevated water levels due to tunnel-leakage influence, when combined with seasonally high water levels, can exacerbate or create localized basement flooding (fig. 7).

\section{Groundwater Temperature}

The digital data loggers installed in wells also record water temperature. Bedrock groundwater temperature within the study area indicates areas of lower temperature that correlate with areas of short tunnel-influence delay time and large water-level changes during tunnel shutdowns (figs. 13, 14 , and 18). During a synoptic water-level measurement in August 2010, groundwater temperature in the bedrock wells was measured manually using a submersible probe. When depths to groundwater exceeded $25 \mathrm{ft}$, temperature data were collected using digital data loggers. Bedrock groundwater temperature ranged from 50 to 56 degrees Fahrenheit $\left({ }^{\circ} \mathrm{F}\right)$ throughout the study area (fig. 18). Water in the Rondout Reservoir downtake (primary reservoir inflow to RWB Tunnel) 


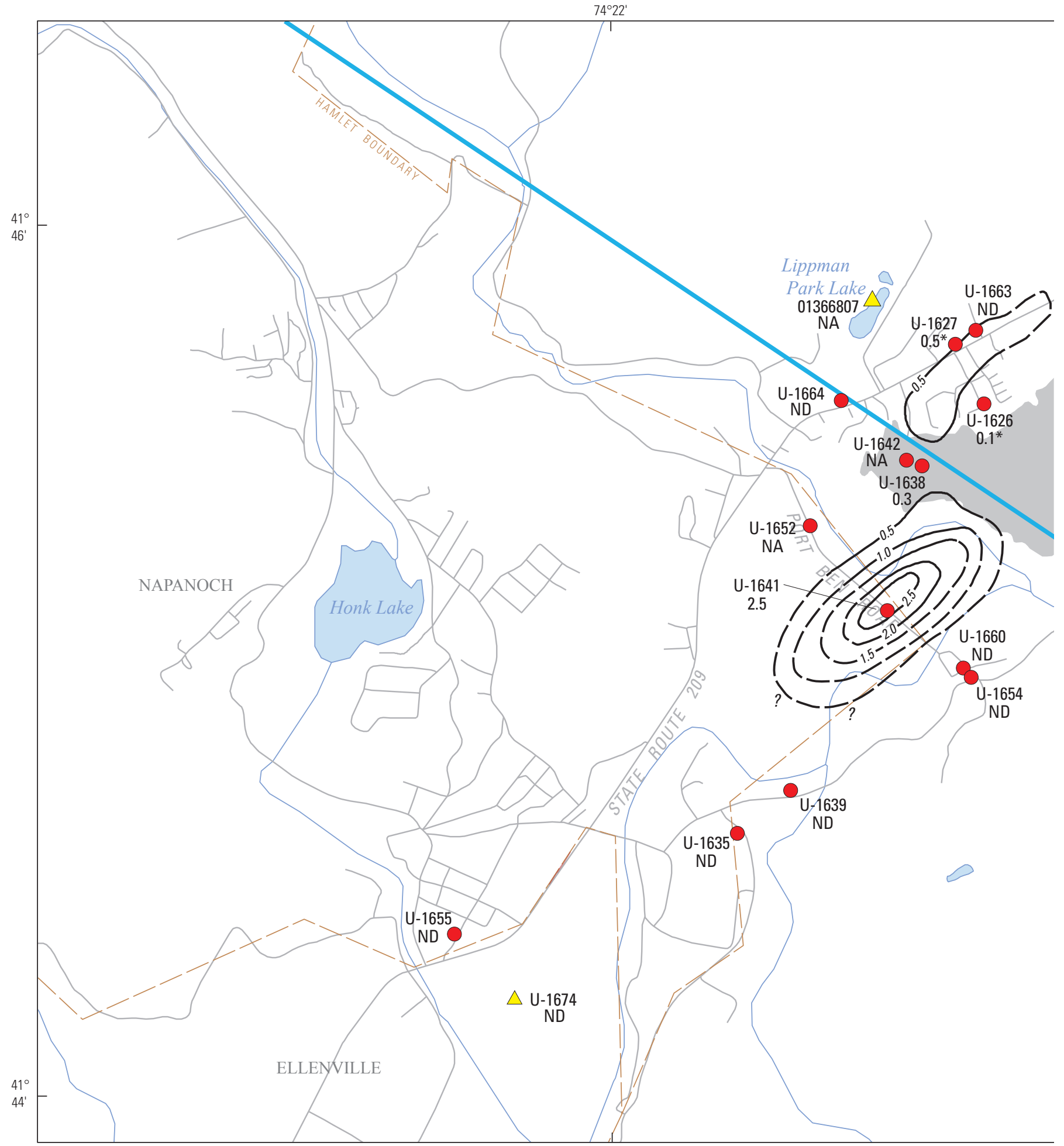

Base from U.S. Geological Survey Digital Data 1:100,000 series Lambert Conformal Conic Projection

North American Datum of 1983

Figure 16. Maximum water-level response to influence of tunnel leakage on the unconsolidated aquifer within the study area, Town of Wawarsing, Ulster County, New York. 


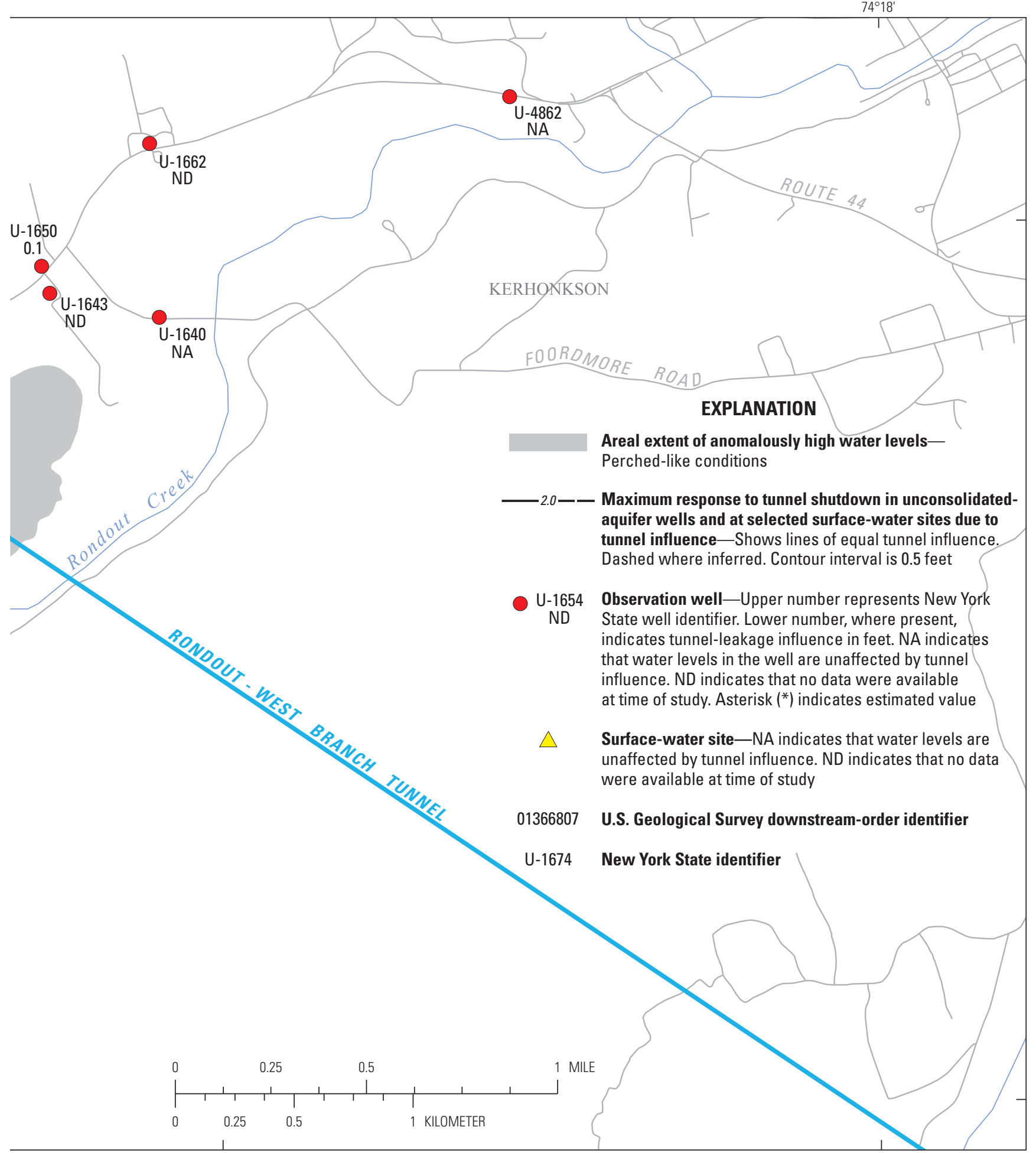

Figure 16. Maximum water-level response to influence of tunnel leakage on the unconsolidated aquifer within the study area, Town of Wawarsing, Ulster County, New York.-Continued 


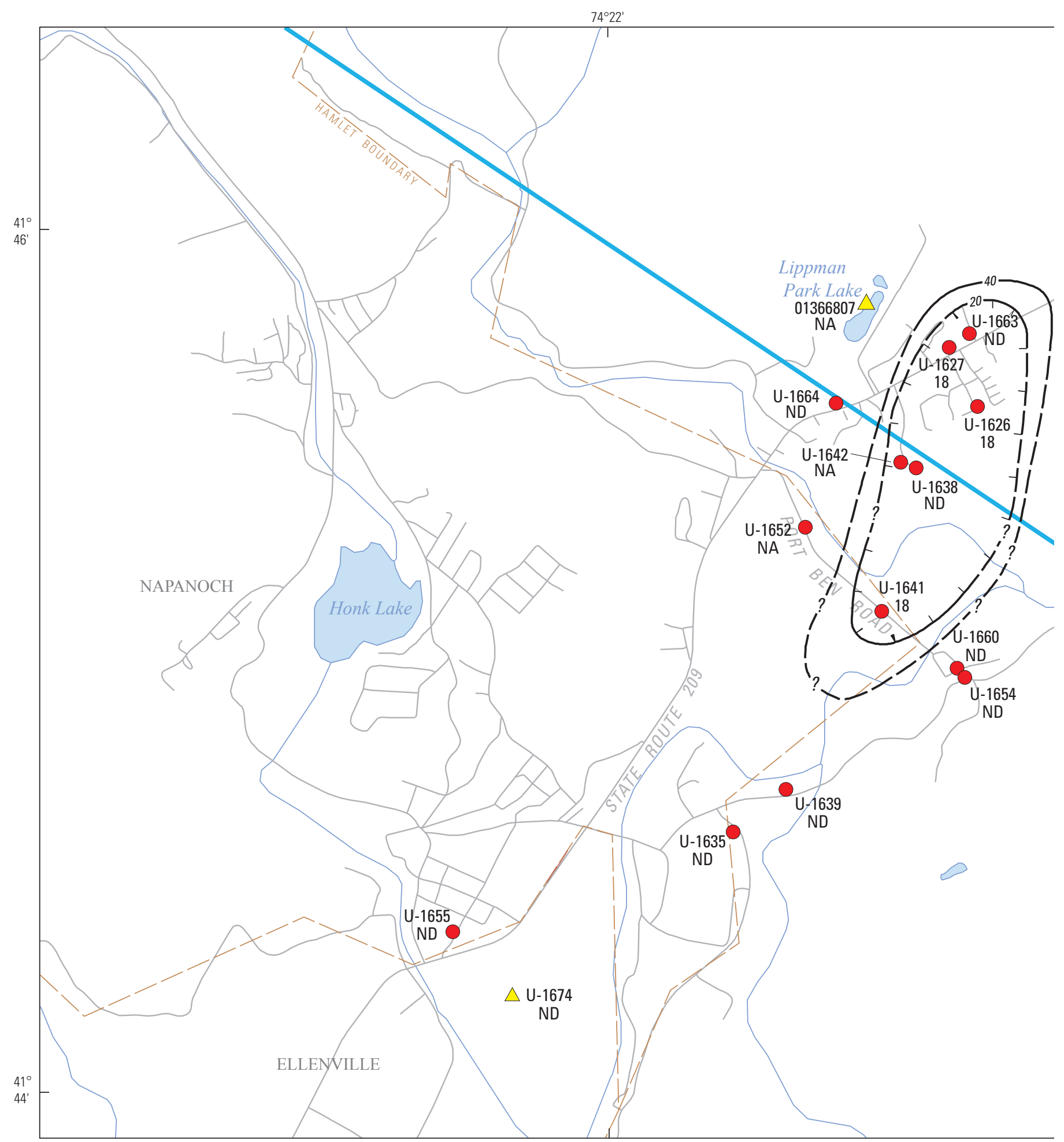

Base from U.S. Geological Survey Digital Data 1:100,000 series Lambert Conformal Conic Projection North American Datum of 1983

Figure 17. Tunnel-leakage influence delay time on water levels in unconsolidated-aquifer wells and surface-water sites within the study area, Town of Wawarsing, Ulster County, New York, 2009-10. 


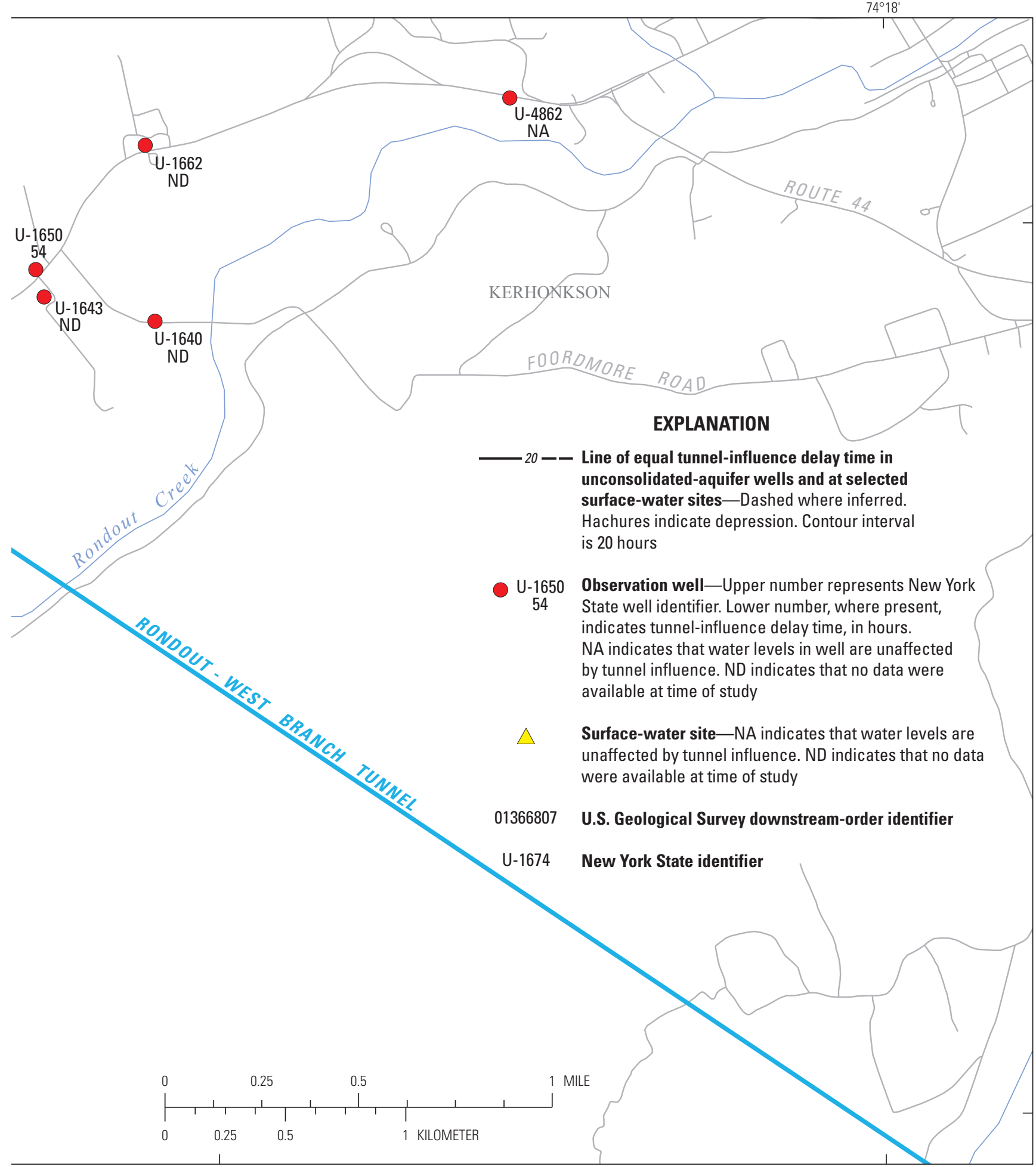

Figure 17. Tunnel-leakage influence delay time on water levels in unconsolidated-aquifer wells and surface-water sites within the study area, Town of Wawarsing, Ulster County, New York, 2009-10.-Continued 


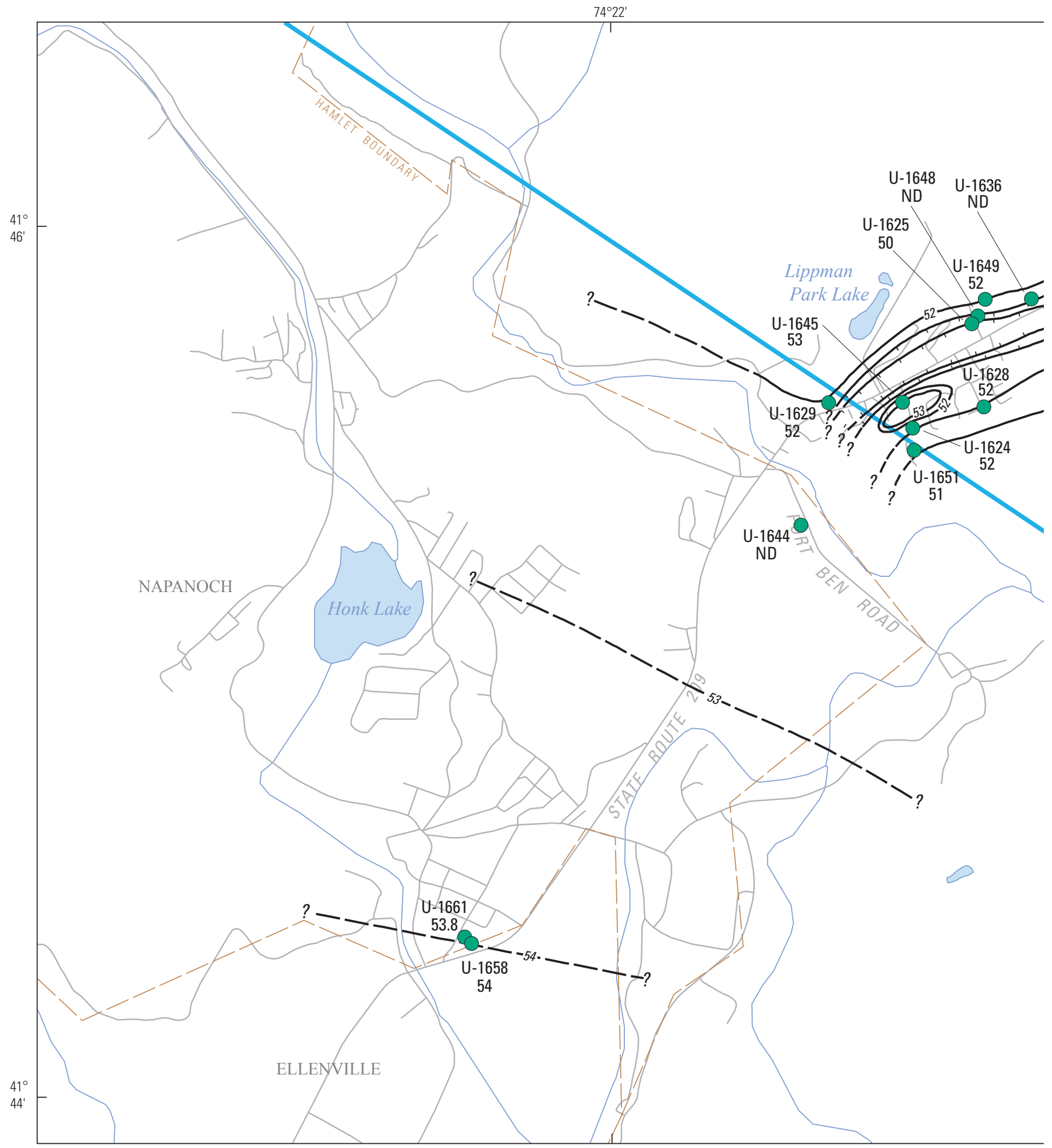

Base from U.S. Geological Survey Digital Data 1:100,000 series Lambert Conformal Conic Projection North American Datum of 1983

Figure 18. Groundwater temperature in bedrock wells within the study area, Town of Wawarsing, Ulster County, New York, August 2010. 


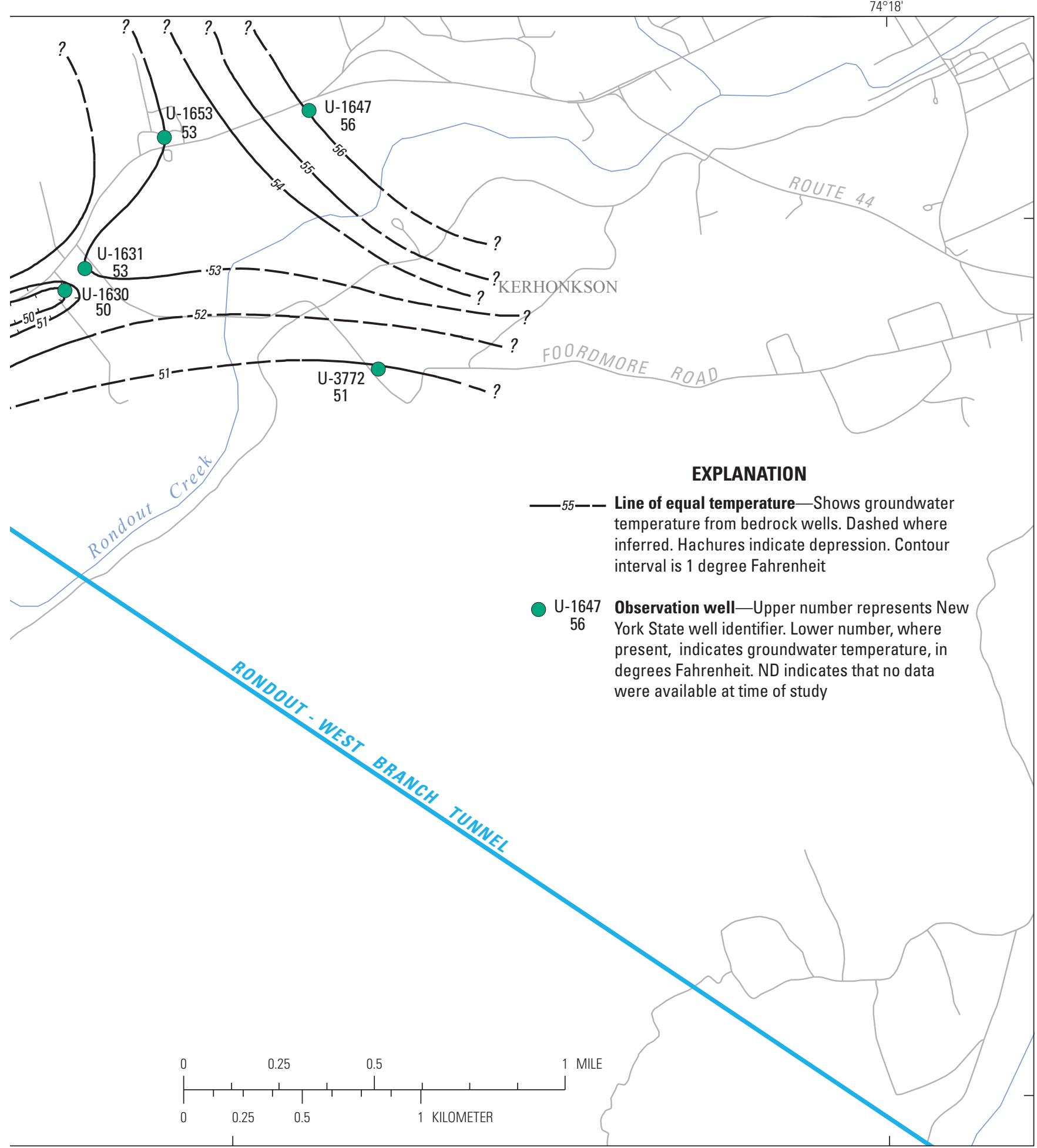

Figure 18. Groundwater temperature in bedrock wells within the study area, Town of Wawarsing, Ulster County, New York, August 2010.-Continued 
was sampled five times during the study and its geochemistry was determined; the temperatures of these samples averaged $51.3^{\circ} \mathrm{F}$ (RWB Tunnel water temperature). Groundwater temperatures in wells U-1625, U-1630, U-1649, and U-1651 were the lowest among those in the monitored bedrock wells (fig. 18). The temperature anomalies delineated on the bedrock water-temperature map (fig. 18) are consistent with the leakage of colder tunnel water into the surrounding fracturedbedrock groundwater-flow system along highly transmissive sections. Bedrock wells with the coldest groundwater temperatures were the same wells that have the largest waterlevel changes and shortest delay times due to tunnel influences (figs. 13,14 , and 18$)$. The low temperatures $\left(51^{\circ} \mathrm{F}\right)$ measured at well U-3772 indicate that tunnel leakage may occur in other parts of the study area where there are no observation wells. Additional work in this part of the study area would provide information on the extent of RWB Tunnel leakage.

Analysis of groundwater temperatures in shallow unconsolidated-aquifer wells indicates no clear patterns. The variable depth, construction characteristics of the wells, and the close proximity of groundwater in the unconsolidated aquifer to the atmosphere produce large variations in temperature that would tend to obscure influences of tunnel leakage.

\section{Summary}

Leakage from the Rondout-West Branch (RWB) Water Tunnel and above-normal precipitation have been suspected of causing elevated groundwater levels and basement flooding in the Town of Wawarsing, New York. The hydrology of a 12-square-mile study area within the Town of Wawarsing was studied during 2008-10. A network of 41 wells (23 unconsolidated-aquifer and 18 bedrock wells) and 2 surface-water sites was used to monitor the hydrologic effects of four RWB Tunnel shutdowns. Inflows from the fractured bedrock that ranged from less than 1 to more than 9,000 gallons per minute (gal/min) were documented during construction of the 13.5-foot (ft)-diameter RWB Water Tunnel through the sedimentary-rock sequence $710 \mathrm{ft}$ beneath the study-area valley.

The study area contains unconsolidated overburden aquifers and bedrock aquifers. The groundwater in the unconsolidated aquifer flows from the surrounding hills east and west of the valley and from the southwest of the valley toward the central and ultimately northeastern part of the valley. The groundwater in the bedrock aquifer flows through a network of interconnected bedrock fractures from higher elevations in the surrounding hills toward the center of the valley.

Water levels indicate that groundwater flows upward from the bedrock to the unconsolidated aquifer under natural conditions with a head difference of $1.8 \mathrm{ft}$. However, most of the bedrock wells had upward flow gradients 1.6 to
5.4 times the normal gradient. This represents a significant flow-gradient potential of RWB Tunnel leakage to the overlying unconsolidated aquifer. In general, water levels in the unconsolidated and bedrock aquifers are highest in two time periods-March, April, and May, and December and January. Water levels are lowest during August, September, and October. One area of anomalously high groundwater levels (perched-like conditions) was observed in the vicinity of well U-1642. The highest vertical gradient observed in any unconsolidated-aquifer well doublet was measured at wells U-1642 and U-1656 as a result of a large mound of clay underlying a hilly deltaic deposit.

Since 2002, annual precipitation in the region has exceeded the long-term mean of the 141-year record in Central Park, N.Y. This unusually high precipitation causes increased groundwater levels and contributes to surface flooding when the rate of precipitation exceeds the rate at which water can drain away from roadways or infiltrate into (recharge) the surficial deposits. Water levels in the unconsolidated and bedrock aquifers varied seasonally as a result of the effects of precipitation, evapotranspiration, and pumpage. In the unconsolidated aquifer, seasonal effects caused water-level differences to range seasonally from $3.5 \mathrm{ft}$ (U-1652) to $6.5 \mathrm{ft}$ (U-1626). On average, the seasonal water-level difference in the unconsolidated aquifer is $5 \mathrm{ft}$. Seasonal water-level differences in the bedrock aquifer ranged from $1.5 \mathrm{ft}$ (U-3772) to $9.5 \mathrm{ft}$ (U-1645). On average, the seasonal water-level difference in the bedrock aquifer is $5.3 \mathrm{ft}$. Seasonal water-level differences in the bedrock aquifer were larger than those in the unconsolidated aquifer.

During the exploration and construction of the Catskill Aqueduct 10 miles north of the RWB Tunnel, caves, cavities, cavernous structures, faults, fractures, and solution joints were encountered in the limestone bedrock. The same bedrock units were found during the exploration and construction of the RWB Tunnel. Groundwater inflows from the limestone exceeded 9,000 gal $/ \mathrm{min}$ in places during tunnel construction. Grouting proved unsuccessful in the Manlius Limestone. Solution cavities, decayed or leached limestone, fractures, fault crush zones, and prominent solution features were encountered during the construction of the RWB Tunnel.

RWB Tunnel leakage caused water levels in some bedrock wells to increase. During tunnel shutdowns, water levels in the bedrock decreased within 0.5 to 60 hours. Bedrock water levels declined from 1.5 to $12 \mathrm{ft}$ during tunnel shutdowns at wells up to $7,000 \mathrm{ft}$ from the tunnel. Tunnelinfluence delay times at most affected bedrock wells ranged from 21 to 33 hours. Water levels in some unconsolidatedaquifer wells responded to tunnel leakage from the underlying bedrock. Maximum water-level changes in the unconsolidated aquifer due to tunnel leakage ranged from 0.1 to $2.5 \mathrm{ft}$. Areas in the unconsolidated aquifer that were influenced by tunnel leakage correlated with areas of bedrock wells influenced by tunnel leakage.

Bedrock groundwater temperature during the synoptic measurements made in August 2010 ranged from 50 to 
56 degrees ${ }^{\circ} \mathrm{F}$ throughout the study area. The Rondout Reservoir downtake temperatures average $51.3^{\circ} \mathrm{F}$. Bedrock wells with the coldest groundwater temperatures were the same wells that have the largest water-level changes and shortest delay times due to tunnel influences.

Given the historical descriptions of solution features, cavities, and fault crush zones, leakage from the RWB Tunnel has the potential to reach highly transmissive areas in the bedrock sequence and to cause the rapid change in water levels in the bedrock aquifer up to 7,000 ft from the tunnel. The concept of a highly transmissive, interconnected network of fractures within the bedrock is supported by the bedrock water-level and temperature data collected. In general, the largest influence on water levels regionally was precipitation, but pumpage and (or) tunnel leakage were large influences in some wells locally. Precipitation and other seasonal effects have the largest influence on water levels in the unconsolidated aquifer. Tunnel leakage from the bedrock was measurable in the unconsolidated aquifer. In the unconsolidated aquifer, elevated water levels due to tunnel-leakage influence, when combined with seasonally high water levels, can exacerbate or create localized basement flooding. A larger network of wells in both the bedrock and unconsolidated aquifers would provide additional data that could increase understanding of this complex system, and would also allow for verification of areas of tunnel leakage and the extent of hydrogeologic deposits. Additional data are needed about the bedrock fracture patterns, bedrock fracture transmissivity, solution-cavity locations, and water levels in areas of the valley where observation wells are currently lacking.

\section{Acknowledgments}

The authors thank the residents of the Town of Wawarsing for providing access to their properties and private-supply wells during this study. Without their assistance, the groundwater data collected for this study would have been limited to data from the 14 U.S. Geological Survey (USGS) unconsolidated-aquifer wells. We also thank Ira Stern and James Canale of the New York City Department of Environmental Protection for their technical support. Thanks are extended to Town of Wawarsing Supervisor Leonard M. Distel for his technical assistance and access to town property. The authors thank James Johnson and Eric Greppo of the New York State Department of Corrections for providing access to observation wells at the Eastern New York Correctional Facility in Napanoch, N.Y. Malcolm Pirnie, Inc., shared their research on the monitoring of springs within the study area. Special thanks are extended to Paul Heisig and Richard Reynolds of the USGS for their help in establishing part of the groundwater network and for their technical support. Thanks are also extended to Jason Finkelstein of the USGS for his geographic information system (GIS) support.

\section{References Cited}

Bartosik, H.J., 2005, Water: The Rondout Valley: Wawarsing. Net Magazine, issue 34, September 2005, p. 20.

Berkey, C.P., 1911, Geology of the New York City (Catskill) aqueduct: New York Education Department Bulletin no. 489, New York State Museum Bulletin 146, 283 p.

Berkey, C.P., and Fluhr, T.W., 1936, The geologic formations of the new Rondout-West Branch Tunnel of the Delaware Aqueduct with generalized geological sections: New York City Board of Water Supply, 59 p.

Bradbury, K.R., and Rothschild, E.R., 1985, A computerized technique for estimating the hydraulic conductivity of aquifers from specific-capacity data: Groundwater, v. 23, no. 2, p. 240-246.

Cadwell, D.H., 1989, Surficial geologic map of New York: Lower Hudson Sheet, New York State Museum and Science Service, Map and Chart Series No. 40, 5 sheets, 1:250,000.

Dibbell, H.A., 1944, Delaware Aqueduct, Rondout-West Branch Tunnel record drawing: New York City Bureau of Water Supply, 96 sheets.

Dinapoli, T.D., 2007, Delaware Aqueduct System-Water leak detection and repair program: New York City Department of Environmental Protection, Office of the New York State Comptroller, Division of State Government Accountability, Report 2005-N-7, 19 p.

Fisher, D.W., Isachsen, Y.W., and Richard, L.V., 1970, Geologic Map of New York: Lower Hudson Sheet, New York State Museum and Science Service, Map and Chart Series No. 15, 1:250,000.

Fluhr, T.W., and Terenzio, V.G., 1973, Geological record of the works of the Board of Water Supply: City of New York, Open File Volume 2, 464 p.

Fluhr, T.W., and Terenzio, V.G., 1984, Engineering geology of the New York City water supply system: New York State Geological Survey Open File Report 05.08.001, 183 p.

Freeze, R.A., and Cherry, J.A., 1979, Groundwater: Englewood Cliffs, N.J., Prentice Hall, Inc., 604 p.

Frimpter, M.H., 1970, Ground-water basic data for Orange and Ulster Counties, New York: New York State Conservation Department Bulletin 65, 93 p.

Frimpter, M.H., 1972, Ground-water resources of Orange and Ulster Counties, New York: U.S. Geological Survey WaterSupply Paper 1985, 80 p.

Merguerian, Charles, 2000, Geology of the New York City Aqueduct System-History and construction of the New York City water supply system in Long Island Geologist Meeting: Long Island, N.Y., October 4, 2000, additional lecture notes, $7 \mathrm{p}$. 
National Oceanic and Atmospheric Administration, 2010, Monthly and annual precipitation at Central Park, Manhattan, New York, accessed March 29, 2011, at http://www.erh.noaa.gov/okx/climate_cms.html.

New York City Board of Water Supply, 1940, Geology as interpreted by borings: Station $283+00$ to station $288+59.5$, plate 1 .

New York City Board of Water Supply, 1941, Proposed steel interliner construction, plate 1 .

New York City Department of Environmental Protection, 2010, History of New York City's water supply system, accessed March 16, 2011, at http://www.nyc.gov/html/dep/ html/drinking_water/history.shtml.

New York State Department of Health, 1982, New York State atlas of community water system sources: New York State Department of Health, Division of Environmental Protection, Bureau of Public Supply Protection, 79 p.
Randall, A.D., 1996, Mean annual runoff, precipitation, and evapotranspiration in the glaciated northeastern United States, 1951-80: U.S. Geological Survey Open-File Report 96-395, 2 pl.

Reynolds, R.J., 2007, Hydrogeologic appraisal of the valleyfill aquifer in the Port Jervis Trough, Sullivan and Ulster Counties, New York: U.S. Geological Survey Scientific Investigations Map 2960, 5 sheets, accessed April 2011, at http://pubs.usgs.gov/sim/2007/2960/.

Soren, Julian, 1961, The ground-water resources of Sullivan County, New York: New York State Department of Conservation Bulletin GW-46, 66 p.

United States Census Bureau, 2010, American Fact Finder, accessed April 1, 2011, at http://factfinder2.census.gov/ faces/tableservices/jsf/pages/productview.xhtml.

Van Diver, B.B., 1989, Roadside geology of New York: Missoula, Mont., Mountain Press Publishing Company, $411 \mathrm{p}$. 
Prepared by the Pembroke and West Trenton

Publishing Service Centers

For additional information write to:

New York Water Science Center

U.S. Geological Survey

425 Jordan Road

Troy, NY 12180

Information requests:

(518) 285-5602

or visit our Web site at:

http://ny.water.usgs.gov 
